\title{
INTERNATIONAL MONETARY FUND WORLD BANK
}

In consultation with the staffs of the Asian Development Bank and the European Bank for Reconstruction and Development

\section{Country Notes: Debt Sustainability And Policy Priorities To Ensure Growth IN THE CIS7 COUNTRIES}

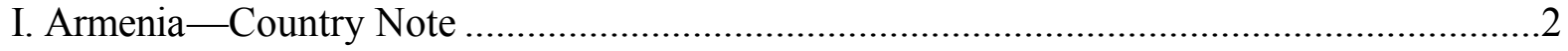

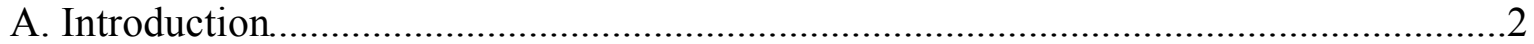

B. Priorities for Future Economic Growth and Poverty Alleviation....................................2

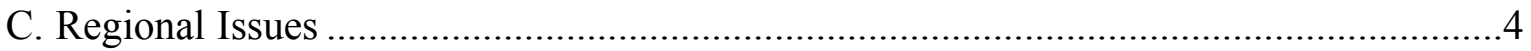

D. Debt Sustainability Scenarios and Strategies...............................................................

II. Georgia - Country Note .....................................................................................

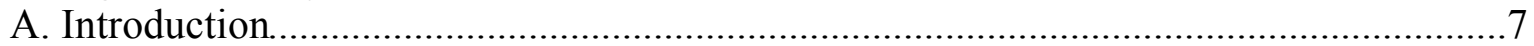

B. Priorities for Future Economic Growth and Poverty Alleviation.................................... 8

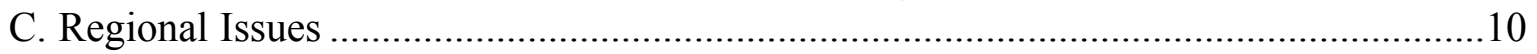

D. Debt Sustainability and Strategies .....................................................................10

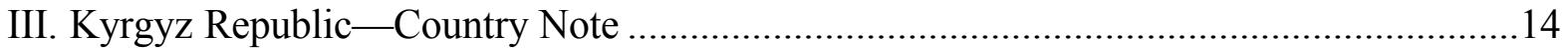

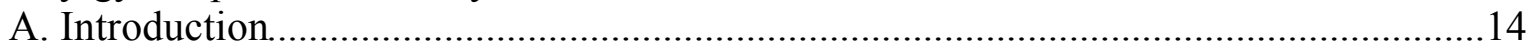

B. Priorities for Future Economic Growth and Poverty Alleviation.....................................14

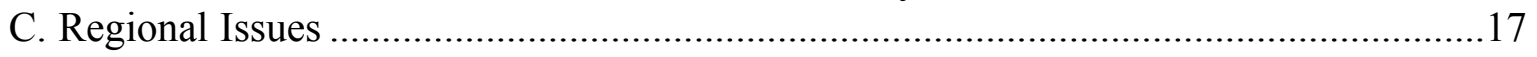

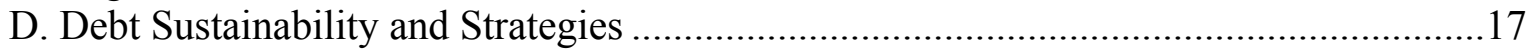

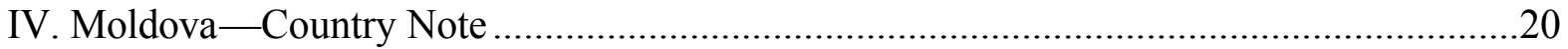

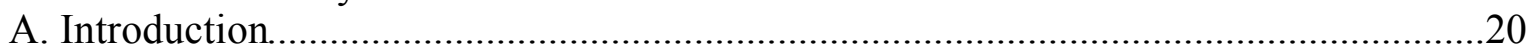

B. Priorities for Future Economic Growth and Poverty Alleviation.................................20

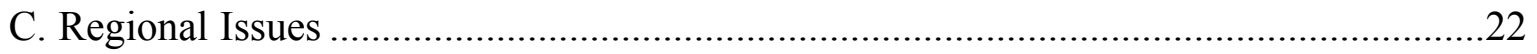

D. Debt Sustainability and Strategies .......................................................................22

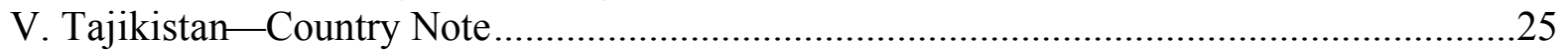

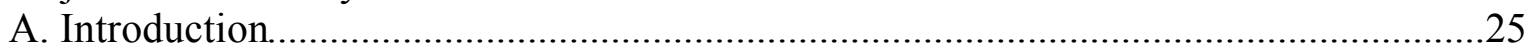

B. Priorities for Future Economic Growth and Poverty Alleviation..................................25

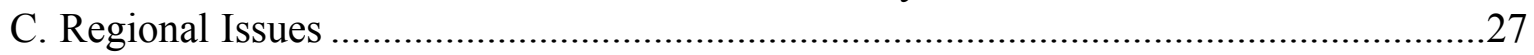

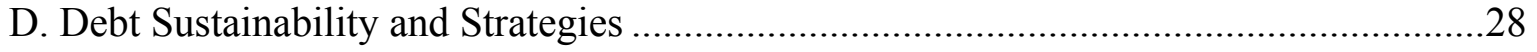

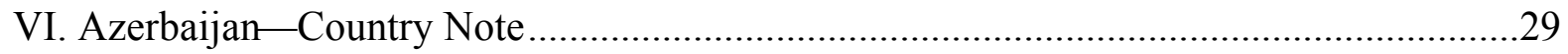

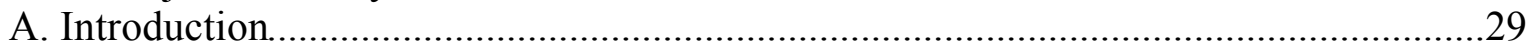

B. Priorities for Future Economic Growth and Poverty Alleviation..................................22

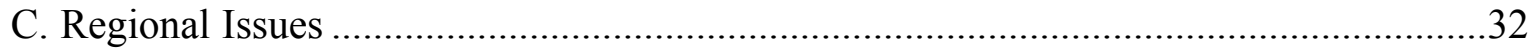

D. Debt Sustainability and Strategies .........................................................................

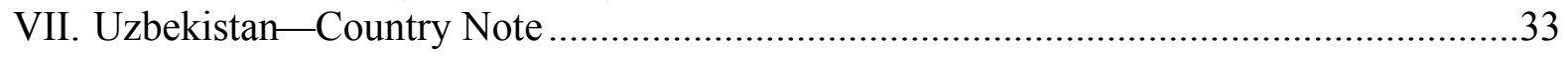

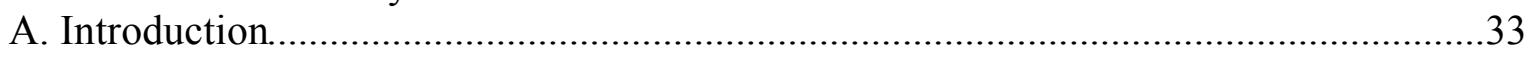

B. Priorities for Future Economic Growth and Poverty Alleviation.....................................34

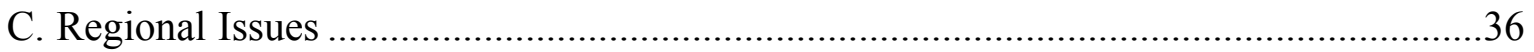

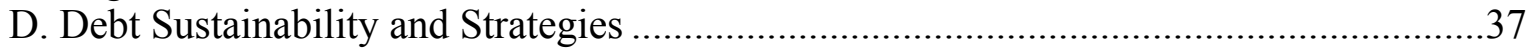




\section{ARMENIA-COUNTRY Note}

\section{A. Introduction}

1. Real GDP in Armenia fell by almost 60 percent between 1991-93, mainly as a result of (i) the collapse of the highly integrated Soviet economy, (ii) a significant deterioration in the terms of trade (as energy and raw material prices within the BRO region were increased), and (iii) conflict in the Caucasus and especially over Nagorno-Karabakh. With the end of hostilities in Karabakh and progress in fighting hyperinflation, real economic growth began in 1994, and over the past eight years has averaged around 51/2 percent per annum, backed by sound macroeconomic policies and significant structural reforms in the areas of the banking sector, establishment of a treasury, strengthening of the social safety net, revising tax laws, the energy sector, and privatization. ODA and unrequited inflows have also been significant, although these inflows did not always support new investments. At the same time, due to continuing (although recently diminishing) large current account deficits, Armenia has built up significant levels of external debt.

2. The revival in economic activity has not been accompanied by rapid enterprise restructuring and entry of new market-based activities, which helps to explain the slow growth of exports in the 1990s and the lack of progress in reducing poverty and unemployment. The share of the population living below the poverty line was 55 percent in 1998/99, and officially registered unemployment remains high, at more than 10 percent of the labor force, despite significant net emigration during the past decade. Armenia also has a very unequal distribution of income relative to all other poor CIS countries, with a high Gini coefficient measured on the basis of income (although the coefficient measured by household expenditure is significantly lower).

3. The Interim Poverty Reduction Strategy Paper (I-PRSP) completed by the Armenian government in March 2001 highlights three main pillars of the country's poverty reduction strategy: (i) sustainable and equitable economic growth; (ii) strengthening public administration and fighting corruption; and (iii) the need to take measures in a wide range of areas - ranging from health, education, social protection to environmental protection - to promote human development.

\section{B. Priorities for Future Economic Growth and Poverty Alleviation}

4. While Armenia has established a liberal domestic and foreign trade environment, most of its growth to date has come from construction, a relatively strong recovery in agriculture backed by the privatization of rural land early in the transition period, recovery in the power supply due to the restarting of the nuclear power plant and the recovery of the supply of natural gas, and expansion of some services. In order to sustain the rate of economic growth and reduce poverty, Armenia will need: (i) a higher level of new entry, 
including foreign direct investment, ${ }^{1}$ in relatively labor intensive industries; (ii) a faster pace of restructuring of the large manufacturing enterprises that were developed in the Soviet era; and (iii) a more pronounced promotion of an efficient and sustainable export basis that is not supported by distortions in the tax system. At the same time, it will be necessary to reduce corruption to ensure that the fruits of rapid growth are spread more widely among the population. In general, a major improvement in public governance is needed to manage more effectively public resources, accelerate a broad range of structural reforms, and to fight corruption.

\section{Further fiscal adjustment is required through some increase in revenue, and a} need for a major restructuring of public expenditure. While the government was able to increase tax revenues and cut wasteful budgetary expenditures in the late 1990s, tax evasion appears to have increased in the last two years, due partly to a weakening of the government's administrative capacity following the October 1999 political assassinations, and there is a limit to how much further expenditure can be cut. It is essential for the government to an aggressive posture against large tax evaders, including by establishing a large taxpayer unit with real collection powers. Moreover, it must implement strong tax administration measures to collect taxes on a sustained basis, including through strengthening the use of taxpayer identification numbers, enforcement, and exchange of information between the customs and inland revenue authorities, and by improving the procedures for collections and audit. It is also necessary to initiate a comprehensive restructuring of expenditure to ensure a significant reallocation of public resources in support of primary social services and basic infrastructure.

\section{The government needs to continue to take a broad range of measures to} strengthen the environment for private investment, especially in small and mediumsized business. Armenian state institutions remain weak despite continuing donor support for judicial reform, efforts to streamline administrative procedures, and the government's stated commitment to develop an anti-corruption strategy. Entrepreneurs frequently complain about non-transparent regulation, cumbersome administrative procedures, and the uneven application of the rule of law. On the more positive side, state intervention in enterprise decisions is relatively low by comparison with other transition economies, the privatization program is far advanced, progress has been made in simplifying tax procedures, and the country maintains a very open trade regime. Nonetheless, while some progress has been made in reducing regulations and other sources of petty harassment and corruption, important steps are needed to reform the judicial system so as to strengthen the environment for implementing bankruptcies and contracts, including the ability of banks to collect collateral. This should be undertaken through further legislative changes, public administration reform,

\footnotetext{
${ }^{1}$ Per capita foreign direct investment (FDI) in Armenia is higher than the average among the CIS countries, but is much behind the levels achieved by many other transition countries.
} 
and capacity building efforts. Assisting small and medium-sized businesses obtain muchneeded bank credit at lower interest rates would also be helpful. ${ }^{2}$

7. A more determined and coordinated effort is needed to encourage FDI. The steps mentioned earlier to improve the business environment should help encourage FDI, but the government can take other important actions as well. One is to make it clear to potential foreign investors, through the carrying out of competitive and fully transparent privatizations of the relatively few remaining large public enterprises, that foreign investors are welcome and will be treated fairly in Armenia. A second means to promote FDI would be to improve the information and other services available to potential investors, including through the Armenian Development Agency.

8. Further, the government needs to regain the momentum of the mid-and late1990s to restructure the energy sector and reduce other quasi-fiscal activities in for instance drinking water and irrigation. Together these activities still represent a major drain on the economy in terms of non-payments and non-collection of taxes, as well as a potential source of increased external debt. Energy sector reform is important in order to reduce financial losses, increase efficiency, and attract investment for much-needed rehabilitation. A fully competitive and transparent privatization of the country's four distribution companies will help increase the financial strength and management capacity of the distribution utilities and attract investors for the next stage of reform, the sale of generation assets. The privatization effort should be complemented by a deepening of reforms in the sector, including, inter alia, further adjustment of energy tariffs, strengthening of the independence of the energy regulator, and improved budget and payments discipline in the public sector with respect to energy consumed by public entities. Reform measures to increase efficiency and unlock investment for replacement capacity are also crucial to prepare for the closure of the nuclear reactor in Medzamor.

9. The government should resolve problems related to the operations of several large industrial enterprises, including the Nairit chemical company. Given recent experience with efforts to privatize these firms, the government should initiate their closure and liquidation without further delay. This would release considerable public resources and send a strong signal to other enterprises regarding the government's commitment to a policy of hard budget constraints.

\section{Regional Issues}

10. The lack of a permanent settlement of the Nagorno-Karabakh dispute is an important hindrance to trade and investment, and progress in resolving this dispute could lead to an

${ }^{2}$ The Armenian banking sector remains underdeveloped and commercial funding can be difficult to obtain, and hence interest rates are still high and the offered maturities are extremely short. 
opening of Armenia's borders and significantly improve the country's prospects for economic growth. Improved regional cooperation is also important for increasing the efficiency of the energy sector, further developing the telecommunications sector, and improving the efficiency of water resource utilization. Tax harmonization throughout the region could also assist in reducing smuggling.

\section{Debt Sustainability Scenarios and Strategies ${ }^{3}$}

11. The baseline projections incorporate the following key assumptions: (i) real GDP growth is projected at 6 percent in 2002-03, and 5 percent during 2004-10; (ii) economic expansion will be led by exports, and will be financed mainly by buoyant FDI inflows; (iii) the real effective exchange rate remains constant from end-2001 onwards; (iv) exports will expand by $81 / 2$ percent annually (compared with an average of 9 percent during 1995 to 2001); and (v) underlying merchandise imports (total imports less humanitarian imports and imports of uncut diamonds) will expand by 6 percent annually. The baseline also assumes that (i) the ceasefire with Azerbaijan will hold (but no permanent settlement of the Nagorno-Karabakh problem is achieved); (ii) Armenia's trading links are not further constrained; and (iii) there will be no major natural disasters.

12. Based on IMF and World Bank supported program projections, Armenia should not need restructuring of bilateral debt. The net present value of debt service as a ratio of exports is expected to decline from 135 percent in 2000 to around 112 percent in 2010. As a share of fiscal revenue, the net present value (NPV) of debt burden is also projected to fall from 177 percent in 2000 to around 150 percent in 2010.

13. With lower growth and exports, the ratio of NPV of debt service to exports wo uld increase rapidly and could exceed 150 percent of exports from 2009 onwards. In this case, sustainability can be restored through an additional $1 / 4$ percentage point of GDP fiscal adjustment? beyond that assumed in the program? if implemented from 2003 onwards, which the staff feels would be difficult, but achievable. In particular, in order to keep external debt sustainable in the downside risk scenario, it is necessary from 2003 on to target a lowering of the baseline scenario's fiscal deficit by about $1 / 4$ percentage point, or from $2 \frac{1}{2}$ percent of GDP (of which $1 / 2$ percent is domestically financed) to $2 \frac{1}{4}$ percent of GDP (with $1 / 4$ percentage point of GDP in domestic financing). This adjustment would be consistent with a higher revenue effort of roughly $1 / 4$ percent of GDP. Alternatively, external debt sustainability could be restored through a Paris Club rescheduling on Naples terms in 2009 when the external debt becomes unsustainable. ${ }^{4}$

\footnotetext{
${ }^{3}$ See Appendix Tables 9a-b and 10a-b and Appendix Figure 1.

${ }^{4}$ In the downside risk scenario and witho ut any fiscal adjustment, external debt is not unsustainable until 2009 and the stock of debt operation would therefore take place in 2011;
} 
14. The authorities are cognizant of the need to lower the external debt burden. In addition to encouraging exports and lowering the budget deficit, especially the externallyfinanced share of this deficit, the authorities' external debt strategy consists of refraining from any new non-concessional debt and using part of the privatization proceeds to prepay existing non-concessional debt.

15. Armenia has good prospects for obtaining significant privatization proceeds including from the pending sale of the electricity distribution companies. However, given the large uncertainty with regards to timing and magnitude of such proceeds, the IMF/World Bank staffs' external debt and fiscal projections in both baseline and down side scenarios do not incorporate their use. In the baseline scenario, external debt is sustainable even in the absence of any privatization proceeds. Should privatization proceeds materialize, the fiscal adjustment needed in the downside scenario would be less than the 1 percent of GDP estimated.

16. Armenia receives a substantial amount of ODA (close to 10 percent of GDP in 2000). In the baseline scenario external debt is sustainable even though it is assumed that ODA relative to GDP falls gradually over time (to around $2 \frac{1}{2}$ percent of GDP in 2010). In the downside scenario, higher ODA could help mitigate the additional higher external debt burden or the costs of the additional fiscal effort that would be needed in order to maintain debt sustainability in a less favorable environment.

i.e., outside of the projection period. Flow rescheduling in 2009 and 2010 are not sufficient to ensure debt sustainability in these two years. 


\section{GEORGIA-COUNTRY NOTE}

\section{A. Introduction}

17. Georgia has faced numerous economic challenges since its independence. In addition to the loss of privileged access to the Soviet market, its place as a popular tourism destination, and internal armed conflict, GDP growth has been lackluster since the Russian crisis in 1998, reflecting energy supply problems, two major droughts, and slow progress on structural reform. With one of the lowest tax/GDP ratios in the region, public finances have been too weak to provide an effective social safety net and the basic physical infrastructure. Corruption has undermined private sector development, fiscal stability, and fiscal management. The budget has accumulated large expenditure arrears, including on wages and pensions. External debt is high and, at the end of 2000, Georgia had run up \$180 million in principal arrears to Turkmenistan.

18. Weak economic growth since 1998 has been accompanied by an increase in poverty, from 14 percent of the population in 1997 to over 20 percent in 1998-2000. ${ }^{5}$ It is estimated that about 60 percent of the population are at risk of falling into poverty. Inequality has increased and the poor have suffered disproportionately from inadequate access to social services and basic infrastructure. Social indicators, especially in the health sector, have deteriorated: infant mortality has increased by 16 percent, to 23 deaths per thousand births, the number of new cases of tuberculosis has tripled, and malaria is reemerging. In education, there are signs that quality is rapidly declining.

19. The authorities have recently made some progress in addressing macroeconomic imbalances. Inflation has been low, reflecting a prudent monetary policy and reduced domestic public borrowing. The floating exchange rate has been relatively stable since 1999, although it depreciated in 2001 following the Turkish crisis earlier in the year and the dismissal of the Georgian government in November. The rapid accumulation of expenditure arrears has been halted since mid-2000. The general government deficit was reduced from almost 7 percent of GDP in 1999 to 4 percent in 2000, and to 2 percent in the first half of 2001, reflecting a sharp reduction in expenditure commitments and a modest improvement in tax collections. On March 6, 2001, Georgia became the second CIS country after Russia to reach an agreement with the Paris Club. However, there remains a hump in debt service in 2003 and 2004, implying a severe liquidity squeeze on the budget in those years, given the low revenue base. The downturn in the world economy and the continuing economic problems in Turkey, Georgia's largest trading partner, have increased the risks to the nearterm macroeconomic outlook.

\footnotetext{
${ }^{5}$ Based on the "official" basket, around 50 percent of the population are below the poverty line.
} 


\section{B. Priorities for Future Economic Growth and Poverty Alleviation}

20. Georgia's growth prospects will depend on the country's ability to increase trade and attract foreign investment. The prospects are helped by Georgia's geographical location (facilitating access to regional markets), good arable land, a relatively well educated labor force, and attractive landscape for tourism. The country lies at the cross-roads between Europe and Asia, as well as between large regional markets. As a consequence, energy transit could be a source of future balance of payments and fiscal inflows. Oil, gas and electricity transit projects have already been undertaken, and more could come on stream within the next three years. Given these medium-term objectives, the following areas outline the key reforms for removing obstacles to poverty reduction and growth.

21. The current low level of fiscal revenues severely constrains social spending and public investment in human capital and infrastructure. Although the tax-to-GDP ratio has doubled between 1995 and 2000, Georgia's fiscal revenues remain too low to finance the provision of satisfactory social services and the public infrastructure needed for private sector growth. General government revenue (excluding grants) amounted to 15 percent of GDP in 2000, including local revenue of almost 5 percent of GDP and extrabudgetary revenue (mainly pension contributions) of $2 \frac{1}{2}$ percent. The reasons for the low tax rate include corruption, unsecured borders, conflict zones, and a large informal sector. The authorities are working on a tax reform intended to broaden the tax base and improve collection through a simplification of the tax system, especially for SMEs. Raising fiscal revenues will also require strong administrative reforms, especially in the customs area where smuggling and corruption is widespread.

22. Improving the effectiveness of public spending is critical. Not only is the current level of public spending on health, education, and social welfare low, but resources are not well-targeted to meet social objectives. Social spending (including education, health, and social protection) accounted for only 8 percent of GDP in 2000. Pensions and some publicsector wages are below the poverty line, while the public sector remains overstaffed and inadequately trained. An important recent improvement has been that the state has incurred no additional budgetary arrears, on a net basis, since mid-2000. Some progress has also been made by introducing targeted budget allowances to poor families, but access to health and education services remains constrained. Apart from downsizing the number of public staff and facilities, and it may also be necessary to narrow the scope of public education and health services.

\section{Agriculture will be an important source of economic growth and rural} employment. Georgia has the potential to become a net exporter of agricultural products (particularly high value products such as wine, nuts, mineral water, tea, spices, citrus, fruit juices), but for the most part it has been unable to produce the quality and scale necessary to gain market access. The sector is dependent on irrigation (in the east) and drainage (in the west). Yields are low, as the necessary infrastructure has virtually collapsed due to war, vandalism, and lack of maintenance. Attracting foreign direct investment - both for financing and for technological transfer-is essential for the development of commercial agriculture. In 
addition, the domestic banking sector needs to be strengthened to make resources available to the agricultural sector on market terms. The government can also assist with selective investments in irrigation and through extension services to raise the productivity of small farms. Moreover, the government needs to develop a new land reform policy in the context of expiring land leases.

24. Further reform of the energy sector is needed urgently. The energy sector is burdened with corruption, theft, low collection rates, and an outdated capital stock. As a result, there are frequent power cuts and little electricity supply during the winter, disrupting and discouraging investment and production. Tariffs are relatively high in comparison to other CIS countries, but non-payment by enterprises, households, and government alike severely undermines the financial viability of the sector. The authorities are in the process of reforming the sector, with a focus on private sector investment and management.

The 1997 energy law established an independent regulator (although official interference is still a problem) and set the framework for industry restructuring. Some positive results have emerged from the 1998 privatization of electricity distribution in Tbilisi: collection rates increased from around 15 percent of obligations by final users to around 60 percent through a combination of re-metering, disconnecting non-paying customers, and a public awareness campaign. However, the prospects for further privatization of the sector are bleak, given low investor interest. To improve financial discipline in the system, the government plans to hire private firms to manage electricity transmission and dispatch companies, and the wholesale electricity market. The government also plans to consolidate the remaining public distribution companies and place them under private management. Another important issue is to enhance the medium-term stability of electricity generation, possibly through rehabilitation of the local power generation company.

\section{Widespread governance problems and an unstable legal and tax environment} are inhibiting investment and private sector development. Corruption and lack of regulatory stability drive many small and medium-sized enterprises into the shadow economy; while SMEs contribute 15 percent of total output in the formal sector, their contribution to total output could be as high as 40 percent once the informal sector is taken into account. Further, the process of refunding VAT is unreliable, placing a heavy tax burden on export industries in particular. The government is working on several reforms to improve the business climate, including in taxation, licensing, transport visas, and procurement reform. Initial steps have also been taken to reduce the problem of corruption, with the establishment of an Anti-Corruption Committee, the publication of a medium-term anticorruption strategy, and a Presidential decree on short-term anti-corruption measures. However, much more substantial progress is needed in this area.

26. After some progress, a poor investment climate is constraining the privatization of the rema ining state-owned companies. Compared with other CIS countries, Georgia is relatively advanced in its privatization program. Around 80 percent of the 1,300 small and medium-sized enterprises have been privatized, and there is evidence that some of these have subsequently been successfully restructured. However, several large enterprises remain to be privatized, and attracting credible investors has been difficult. Moreover, some privatizations 
were stopped due to concerns regarding social impacts of post-privatization restructuring. Lack of investor interest to a tender in 2001 has also led to a delay in the privatization of the two state telecommunications companies.

27. The banking sector has been substantially restructured, but it remains small and weak, inhibiting domestic savings and investment. Household deposits with commercial banks account for less than 2 percent of GDP, and bank loans for less than 7 percent of GDP. Both loans and deposits are primarily in foreign currency, which makes the banking system vulnerable to foreign exchange and credit risk. The central bank has recently made progress in strengthening its supervisory capacities and raising transparency in the sector. New asset classification rules and international accounting standards have been adopted, and the minimum capital requirement has been raised. However, enforcement of these standards is likely to require further closures of problem banks. The sector could benefit from the entry of strategic investors.

\section{Regional Issues}

28. While domestic reforms are necessary for growth and poverty reduction, Georgia could also benefit from enhanced regional cooperation. First, better cooperation, political stability, and perhaps tax harmonization is needed with Turkey, Russia, Armenia, and Azerbaijan to secure the borders and reduce smuggling. Second, Georgia's location makes it an attractive country for interregional trade. Several oil and gas pipeline projects are planned and transit trade through the road and rail network could see substantial growth. At present, Georgia enjoys higher than normal transit as the trade blockades (between Armenia-Turkey and Armenia-Azerbaijan) have interrupted traditional trade routes. However, while the statutory trade regime within the region is liberal, progress is needed in removing non-tariff barriers to trade (such as high transit fees, checkpoints) which increase transport costs. An eventual resolution of the regional conflicts might reduce transit through Georgian territory, but the country would benefit from increased economic activity in the region. Finally, a political solution for Georgia's break-away regions may require close cooperation with Russia.

\section{Debt Sustainability and Strategies ${ }^{6}$}

29. Georgia's debt problems originated in the years immediately following independence. By end-1994, it had already accumulated \$1 billion in external debts, almost half of which were incurred as a result of unpaid gas imports from Turkmenistan. Between 1995 and 1998, Georgia negotiated 11 separate rescheduling agreements with its bilateral creditors, but soon began to accumulate arrears to Turkmenistan on the rescheduled maturities. In the meantime, the stock of external debt increased further, reflecting concessional lending by multilaterals,

\footnotetext{
${ }^{6}$ See Appendix Tables $11 \mathrm{a}-\mathrm{b}$ and $12 \mathrm{a}-\mathrm{b}$ and Appendix Figure 2.
} 
aimed at supporting Georgia's efforts to promote macroeconomic stabilization and structural reform.

30. The stock of external debt, as a share of exports or GDP, is not unusually high and most liabilities carry relatively low interest rates (4 percent on most bilateral debt and concessional rates on most multilateral debt). Georgia's main vulnerability is a lack of public sector liquidity, with near-term debt service obligations accounting for a high share of fiscal revenues and of gross reserves. Despite the earlier bilateral rescheduling agreements, scheduled debt service in 2000 (mostly on bilateral debt) amounted to almost 60 percent of central budget revenues and over 150 percent of gross reserves. Georgia's weak liquidity position partly reflects slower than expected fiscal improvements and low gross reserves resulting from persistent external imbalances and the aftermath of the Russian crisis.

31. In the context of the PRGF-supported program for 2001-03, the authorities committed themselves to pursue four goals to address the debt problem: (i) achieve a substantial fiscal adjustment, by reducing the commitments deficit, repaying domestic expenditure arrears, and raising fiscal revenues, mainly through reforms in tax and customs administration; (ii) accelerate structural reforms that support growth and poverty reduction; (iii) continue to work with international institutions and donors to attract technical assistance, as well as concessional loans and grants, while not contracting any new nonconcessional debt; and (iv) pursue debt rescheduling under the aegis of the Paris Club.

32. The Paris Club agreement reached in March 2001 provides for the rescheduling of 2001/02 principal payments (totaling \$240 million) over 20 years, based on a cut off date of November 1999, and an interest rate of 4 percent for most of the debt. Roughly 80 percent of the total rescheduled amount would come from non-Paris Club members, in particular from Turkmenistan. ${ }^{7}$ The Paris Club agreement effectively reduced the net present value of end-2000 debt by $\$ 56$ million. While the rescheduling provides significant relief in the near term, there remains a hump in debt service in 2003/04.

33. Program scenario: Tables 11a and 12a show a scenario for 2001-10, based on the following assumptions about the external environment and policy implementation:

(i) average GDP growth rate of $3 \frac{3}{4}$ percent; (ii) inflation of around 5 percent, in line with monetary policy objectives; (iii) an increase in the tax-to-GDP ratio for the general government by half a percentage point each year; (iv) repayment of domestic expenditure arrears of around lari 300 million (5 percent of 2000 GDP) during 2001 to 2005;

(v) concessional foreign loan disbursements to the budget of around $\$ 80$ million per year, plus \$20-30 million in non-project grants, broadly in line with recent levels; (vi) gradual

${ }^{7}$ Although Turkmenistan has not agreed with this arrangement, in line with Paris Club comparability practices, Turkmenistan's debt is being serviced in a similar manner as that for Paris Club debts. 
improvement in gross reserves; (vii) a stable exports-to-GDP ratio; and (viii) a stable real exchange rate.

34. Under these assumptions, the current account deficit is projected to fall gradually, with a temporary increase in 2004/05, reflecting oil and gas pipeline investments. The medium-term balance of payments shows financing gaps during the period 2002 to 2007, reaching a peak of almost $\$ 90$ million in 2004. Table 11a shows that debt service increases sharply in 2003, following the expiration of the Paris Club consolidation period. There would be a severe liquidity squeeze, as debt service would amount to over 40 percent of central government revenues and over 80 percent of reserves. Debt indicators are projected to improve after 2004, thanks to growing fiscal revenues, growing official reserves, and a relatively positive macroeconomic environment. The net present value of the total debt stock, as a share of exports, declines gradually, from about 100 percent to about 60 percent in 2010 . The net present value of debt as a share of central government revenues, at over 300 percent in 2001 , falls to about 150 percent by 2010 .

35. If no additional debt relief is forthcoming, Georgia would need to respond to the liquidity squeeze in 2003/04 (even in the program scenario) by keeping a tight lid on fiscal spending. in this case, the fiscal deficit would be reduced by 5 percentage points of GDP between 2000 to 2004, implying a primary surplus of 3 percent of GDP in 2004 . Whereas general government tax revenue, as a share in GDP, would rise from 141/4 percent in 2000 to $16 \frac{1}{4}$ percent by 2004 , expenditure commitments would have to remain stagnant at 2 percentage points of GDP below their 2000 level (which in turn is 2 percentage points below previous years).

36. Low case scenario: Tables $11 \mathrm{~b}$ and $12 \mathrm{~b}$ contrast the program scenario with a "low case" scenario that highlights the country's vulnerability in case GDP and export growth fall short of expectations over a prolonged period and tax revenues do not grow as rapidly as assumed above. With lower export growth, the low case scenario produces current account deficits well above the program case. It is assumed that the resulting external gaps are filled partly through lower reserve accumulation (subject to a minimum reserve level of one month of imports of goods and services) and partly through exceptional financing.

37. In the low case, the net present value of debt would remain at around 100 percent of exports of goods and services throughout the forecasting period. Liquidity problems emerge at the end of the consolidation period under the Paris Club agreement, as in the program case. However, the liquidity pressures are more pronounced and do not abate after 2004. Debt service remains at over 30 percent of central government revenues through the entire projection period (an average of 7 percentage points higher than under the base case), and reaches over 125 percent of gross reserves by 2010 . The tighter liquidity situation in the low case scenario also implies that Georgia is significantly more vulnerable to shocks, such as a temporary real depreciation.

38. Fiscal adjustment under the PRGF-supported program is already ambitious, given the assumed improvement in fiscal revenues and the decrease of the general government deficit 
from over 6 percent in recent years to near balance in 2002 and 2003. While a permanent increase in the tax-to-GDP ratio and restrained growth in fiscal expenditures are key to longterm debt sustainability in Georgia, the degree of expenditure restraint required to maintain external solvency in 2003 and 2004 is probably inconsistent with social objectives, even under program assumptions. Current spending levels are already well below recent years and insufficient to finance the public investment and social spending needed to ensure high growth and a significant reduction in poverty. The scope for significant additional privatization revenues is also limited.

39. To ease near-term liquidity pressures on public finances, Georgia is likely to return to the Paris Club to request further assistance, especially for 2003 and 2004. A flow rescheduling might be sufficient in the program case, but Table 11b shows that Naples flow and stock terms will be necessary for debt sustainability in the low case. Even then, the net present value of debt would remain at about 250 percent of central government revenues.

40. In addition, the Georgian authorities would have to explore options for additional technical assistance and concessional lending from multilaterals and ODA from bilateral donors. Credible progress in structural reforms will be required to justify an extension of these types of assistance. 


\section{KYRGYZ R EPUBLIC-COUNTRY NOTE}

\section{A. Introduction}

41. The economic performance of the Kyrgyz Republic was strong in 2001. Real GDP continued to grow at an annual rate of about 5 percent and the 12-month inflation rate declined to around 4 percent. The nominal exchange rate has remained stable and the demand for money has increased. Nominal and real interest rates have declined. In the area of structural reform, the government recapitalized a systemically important commercial bank and placed four problem banks under liquidation. The number of government ministries and state committees has been reduced - an initial step in the overall program to reorganize the public sector highlighted in the interim PRSP. Electricity tariffs, although still low, have been increased to improve cost recovery and reduce the sector's quasi-fiscal deficit. The process of unbundling the electricity monopoly into six separate companies is well advanced. To offset the adverse effects on the poor, most social benefits have been raised.

42. Despite solid economic growth in the past five years, poverty reduction was hampered by the impact of the 1998 Russian crisis and ineffective social safety nets. The Kyrgyz Republic is the second poorest country of the former Soviet Union, both in terms of per capita income and poverty incidence. Absolute poverty is very high: severe poverty (at PPP \$2.15 per day) affects 18 percent of the population, and 52 percent are considered poor, having income below PPP $\$ 4.30$ per day. Poverty is higher in rural areas, but there are wide disparities in regional poverty. In May, the government completed its interim National Strategy for Poverty Reduction (I-NSPR). With assistance from the World Bank, the authorities plan to conduct a Poverty Assessment (PA) this year, in part to explain why economic growth has not been accompanied by a more significant reduction in poverty. The PA will shape the authorities' policies for poverty reduction, including by providing a basis for the prioritization and costing of public expenditure programs. A full NSPR is expected in September 2002.

\section{B. Priorities for Future Economic Growth and Poverty Alleviation}

43. With a slow projected growth of employment ( $1 / 2$ percent per year) and a modest increase in capital stock, the major contribution to medium term growth is expected to come from improvements in total factor productivity. These improvements are likely to materialize through a further catch-up in the utilization rate of capital and further structural reforms. Although government investment is expected to fall, the adverse impact on growth is likely to be small, as the efficiency of public investment is expected to improve with better prioritization and screening. Moreover, the decline in public investment should be compensated by higher private investment. This would be undertaken by higher FDI, recovering somewhat from its depressed levels in 1998-2000. It would be facilitated by improved resource mobilization by the financial sector, following banking sector reforms, and by reduced pressure on domestic borrowing by the public sector, as the overall fiscal balance (excluding foreign- financed PIP) of the general government swings from a deficit to surplus. The 2002 tax reform, which is expected to lower enterprise taxation, will further 
contribute to private investment. But to achieve these results, the authorities need to address the unsustainable external debt situation, improve regional trade arrangements and strengthen their efforts to introduce a favorable investment climate in the country.

44. Alleviating the external debt problem through fiscal consolidation is necessary for achieving sustainable economic growth. The authorities are targeting a decline in the general government overall fiscal deficit from the projected 6 percent of GDP in 2001 to $2 \frac{1}{2}$ percent in 2004 . This will be achieved mainly through increasing the state budget's taxto-GDP ratio from 13 percent in 2001 to $15 \frac{1}{2}$ percent in 2004 , and a streamlining of the foreign financed PIP from 6 percent of GDP in 2001 to 4 percent by 2004 . The achievement of these targets will depend on the timely implementation of fiscal reforms, including: (i) tax policy changes with a view to achieving a broader tax base with low rates and few simple-toadminister taxes; (ii) the restructuring of the Ministry of Finance to strengthen its ability to implement fiscal policy; (iii) the reform of the treasury system to achieve effective budget execution and control of line ministries' spending commitments to avoid expenditure arrears; and (iv) the strengthening and simplification of tax and customs administration to improve compliance and improve governance.

\section{The framework to prioritize public expenditures must be established.}

Substantially more work will need to be carried out to identify the key public spending policies in line with the priorities in the NSPR and to build the expenditure management institutions that deliver public services and provide a social safety net in an efficient manner. Such expenditure prioritization should be developed in the context of a Medium Term Financial Framework. In particular, plans for current spending should take into account the recurrent cost implications of the targeted social safety net and of the public investment program. At the same time, the PIP should be prioritized with a view to maximizing its overall impact on growth and export potential of the country. Fiscal consolidation should be achieved while ensuring adequate funding for wages to retain qualified civil servants.

46. In particular, the level and composition of social spending needs to be reviewed. Inadequate funding for basic health and education has resulted in informal fees paid by households with detrimental effects on access by the poor to these services. Health and education services as well as other social spending need to be rationalized so that scarce public resources can be utilized effectively. In health care, households practically bear all health risks despite claims of universal coverage. Efforts to address this situation are underway, including reforming the finances of the sector to compensate more directly service providers, downsizing the hospital sector, and reorganizing the structure of health care among different levels of government. Steady implementation of these reforms and adequate funding are the key to success. The provision of basic education appears to be eroding fast for economic reasons as well as poor education policies. Finally, while efforts are being made to introduce more targeted social benefits, the current system is still largely untargeted. The savings stemming from better targeting could be used to expand priority social protection programs. 
47. The restructuring and privatization of the remaining large state-owned enterprises is critical not only for the implementation of the authorities' debt strategy but also because their poor financial performance places a significant drag on potential output growth. The privatization of these enterprises (Kyrgyz Telecom, Kyrgyz Airlines, KyrgyzGaz, and the power sector distribution activities) has been the government's goal for some time, and is noted by the authorities in their I-NSPR. ${ }^{8}$ However, progress has been slow.

\section{The Kyrgyz Republic is endowed with significant hydropower resources, and} could exploit low cost electricity supplies if asset erosion in the sectors is brought under control. Low pricing in the power and gas sectors has created large quasi- fiscal deficits. To date, much of the value added of the energy sector has been re-distributed to the population in a poorly targeted manner through discounted tariffs. As a result, a substantial maintenance backlog has accumulated, threatening the sector's capital base and generating large technical and commercial losses. Furthermore, the power sector has taken numerous external credits under government guarantees, and these contingent liabilities could materialize if the sector's weaknesses are not addressed urgently. Initial reforms have been undertaken. In particular, the state-owned energy company Kyrgyzenergo was divided into generation, distribution and transmission units. Tariffs have been increased and special privileges under the existing electricity tariff structure are being limited. However, there is also a need to set targets for tariff increases, loss reductions, and bill collection rates for 2002-04. While cost recovery in both power and gas is a priority, it is also important to improve transparency and efficiency in management of the power sector, including through involvement in the private sector in the delivery of power.

\section{Reform of the agricultural sector is important to reduce rural poverty.}

Agricultural productivity is low and the poor have little left to sell after their own consumption is met. Increasing agricultural productivity and promoting rural growth through the development of input supply markets and the rehabilitation of infrastructure are critical in this respect. Less government interference in resource allocations - in the seeds, machinery, and fertilizer sectors, as well as the rehabilitation and maintenance of main irrigation channels by government while shifting the responsibility for on- farm irrigation to farmersshould result in increased private investment, agricultural productivity, and higher farm income.

\section{Creating a more favorable business environment is a key to private sector} growth. Although better than in some other poor CIS countries, administrative red tape and interference are often an obstacle to doing business. FDI remains concentrated in the mining sector, and has been seriously hampered by the weak investment climate. A number of

\footnotetext{
${ }^{8}$ Seventy-five percent of privatization receipts from the sale of the four large state-owned enterprises would be used for repayments of external debt respecting the comparability of treatment of creditors.
} 
constraints to small and medium enterprise (SME) development can be addressed through the further reform and restructuring of key sub-sectors. A substantive reform is also needed to simplify regulations on tax and customs administration and develop mechanisms to prevent abuse by tax officials. The streamlining of regulatory and compliance requirements, the strengthe ning of enforcement, and a reduction in corruption are also key areas of focus.

\section{Regional Issues}

51. The Kyrgyz Republic's limited domestic market makes it highly dependent on export opportunities but it faces numerous constraints in regional trade. Trade and transit difficulties, including the imposition of informal charges in neighboring countries, have made it difficult for Kyrgyz entrepreneurs to do business. In particular, SME growth suffers from regional trade restrictions. These difficulties have also obstructed foreign investments into export oriented projects. Further, some neighboring countries follow Custom Union arrangements, while for others the trade arrangements are arbitrary. WTO accession for Kazakhstan and Russia should help streamline trade regimes across the region; the harmonization of trade and custom rules across countries in the region should be pursued.

52. Another regional issue is energy trade. Although the country has substantial power generation capacity, both Uzbekistan and Kazakhstan-which share the grid that was built for the region during Soviet times - focus almost exclusively on securing the availability of water that is released during power generation in the Kyrgyz Republic rather than purchasing energy itself. In addition, the trade in energy takes place largely on an ineffective barter basis.

\section{Debt Sustainability and Strategies 9}

53. At independence, the Kyrgyz Republic was free of external debt, but by 2000 its debt had reached unsustainable levels. The Russian crisis of 1998, and the ensuing depreciation, had a significant effect on debt that reached 130 percent of GDP at end-2000. Scheduled debt service weighs heavily on the budget, absorbing above one third of total revenue and constraining the development of social protection and poverty reduction programs. This burden is expected to increase as the grace periods on several concessional loans expire. In addition, the debt overhang discourages foreign investors.

54. At end-2000, the Kyrgyz Republic's total external debt amounted to \$1.7 billion, 57 percent of which was owed to International Financial Institutions (IFI). Bilateral debts accounted for 29 percent of the total and the remainder was due to commercial creditors (14 percent). The World Bank is the largest multilateral creditor (\$378 million) followed by the Asian Development Bank (AsDB) (\$256 million) and the IMF (\$191 million). Russia and Japan are the largest bilateral creditors. As the bulk of the debt is highly concessional, the net present value (NPV) of total debt amounted to \$1.1 billion. The NPV of debt-to-export ratio

${ }^{9}$ See Appendix Tables $13 \mathrm{a}-\mathrm{b}$ and $14 \mathrm{a}-\mathrm{b}$ and Appendix Figure 3. 
was 197 percent with the NPV of debt relative to fiscal revenue at about 570 percent at end2000. Especially worrisome are the liquidity ratios. ${ }^{10}$ Debt service to exports ratio and debt service-to-fiscal revenue ratio were both about 30 percent. $^{11}$

55. The recent paper on external debt in five low-income CIS countries concluded that the debt situation in the Kyrgyz Republic was most distressing. ${ }^{12}$ With new baseline

macroeconomic assumptions, the debt ratios are substantially higher than that paper. The NPV of debt-to-export ratio is above 210 percent in 2001, remains above 200 percent until 2006 and is still above 150 percent in 2010 (Appendix Figure 3). In this scenario, the country would remain very vulnerable to exogenous shocks that could compromise its capacity to honor its debt.

56. Without strong fiscal adjustment, external debt remains unsustainable. The government has approved a debt reduction strategy prepared in collaboration with the staffs of the IMF and World Bank. This strategy calls for a streamlining of the public investment program, accepting new loans only with a high grant element, and a program of debt repayments, ${ }^{13}$ potential proceeds from privatization, debt-equity swaps, and other sources. The combined effect of this set of measures is substantial. The NPV of debt-to-export ratio declines by 13 percentage points by 2004, and falls below 150 percent in 2010. Similarly, the NPV of debt-to-government revenues ratio improves by 20 percentage points by 2004 , and declines below 250 percent in 2008 .

57. Even after the successful implementation of the debt strategy, however, debt indicators remain excessively high in the medium term. Two scenarios were developed to illustrate the impact of a possible relief from Paris Club reschedulings. First, a flow rescheduling on Houston terms for the period December 2001-December 2010 was applied. Second, a three-year flow rescheduling on Naples terms followed by a stock rescheduling on Naples terms. The former operation would have a positive effect on the debt service. However, the NPV of debt would remain high for the rest of the decade as the rescheduling is on non-concessional terms.

${ }^{10}$ Following a standard procedure, the debt service-to-export ratio is built on a three-year export average.

${ }^{11}$ Kumtor related debt service is excluded from the debt service-to-fiscal revenue ratio, while debt service-to-export ratio, NPV of debt-to-export ratio and NPV of debt-to-fiscal revenue ratio are presented in Table 2 including the Kumtor debt.

12 "Republic of Armenia, Georgia, Kyrgyz Republic, Republic of Moldova, and Republic of Tajikistan—External Debt and Fiscal Sustainability," February 6, 2001, (http://www.imf.org./externa1/np/eu2/2001/edebt/eng/index.htm).

${ }^{13}$ Respecting the comparability of treatment of creditors. 
58. The Kyrgyz Republic will require additional assistance in the form of debt rescheduling and highly concessional financing in order to achieve debt sustainability and sustain economic growth. A Paris Club flow rescheduling on Naples terms for the period December 2001-December 2004, followed by a stock rescheduling under Naples terms with cutoff and operation date December 2004, would provide a significant improvement in the NPV-of-debt and liquidity ratios. With the stock rescheduling, NPV of debt-to-export ratio would fall below 150 percent in 2008 and NPV of debt-to-revenue ratio would decrease below 250 in 2006. Furthermore, debt service would absorb a manageable portion of fiscal revenues and export receipts.

59. Low case scenario. Applying weaker GDP and export growth (by two percentage points) implies that the Kyrgyz Republic is likely to need relief under the enhanced HIPC Initiative. It would face a 170 percent NPV of debt-to-export ratio, a 300 percent NPV of debt-to-revenue ratio, and about 15 percent debt service-to-export ratio. The debt service-tofiscal revenue ratio would increase from 18 percent in 2002 to 23 percent in 2010. Even with relief from commercial and bilateral creditors on Naples terms, under the low case assumptions the Kyrgyz Republic would have debt indicators that are persistently above the thresholds established under the enhanced HIPC Initiative. 


\section{Moldova-CounTRY Note}

\section{A. Introduction}

60. Starting out at independence as a middle-income country, per capita GDP in Moldova has now declined to about $\$ 400$, only one-third of pre-transition levels. This poor economic performance can be attributed to several factors: (i) the collapse of the former Soviet Union and its trade and payments relations; (ii) the adjustment of import prices, notably those of energy, to world levels; (iii) political instability (12 governments in 10 years, plus an internal conflict); (iv) the partial and stop-go nature of the implementation of reform measures; (v) a weak institutional capacity; and (vi) a high vulnerability to external shocks, such as adverse weather conditions.

61. As a consequence, income inequality has widened and absolute poverty has increased dramatically; over half of all households consume less than the subsistence minimum and poverty levels are amongst the worst of the CIS nations. Poverty rates increased significantly after the Russian crisis of 1998. The 2001 Human Development Index ranked Moldova $98^{\text {th }}$ among the 162 world countries covered.

62. Since 1999, the Moldovan authorities have implemented sound macroeconomic policies and accelerated the implementation of structural reforms in order to stimulate growth. Fiscal adjustment has been dramatic; the general government budget deficit was reduced by $7 \frac{1}{2}$ percent of GDP in 1999-2000. Aided as well by a more favorable external environment, the results of these steps have been encouraging: real GDP grew by almost 2 percent in 2000 (only the second year of growth since independence) and is expected to grow by at least 5 percent in 2001. After a resurgence of inflation in the wake of the sharp exchange rate depreciation in 1998, tight credit policies have brought twelve-month inflation down to $43 / 4$ percent by end-September 2001 , while the economy is gradually but steadily remonetizing.

63. Nonetheless, although structural reforms have been accelerated in recent years, transformation to a market economy is far from complete. While land reform is almost completed, the government has only recently started with the privatization of key economic sectors, such as agro-processing, energy companies, and telecommunications. The institutional framework and the overall investment climate are still relatively poor, with high levels of bureaucracy, corruption and harassment, resulting in high costs of doing business.

64. As noted below, Moldova also faces a large external debt burden (in 2000 the stock of public and publicly guaranteed debt stood at 72 percent of GDP) and debt service obligations absorb over 40 percent of central government revenues, reducing resources available for social expenditures in particular and for the country's development in general.

\section{B. Priorities for Future Economic Growth and Poverty Alleviation}

65. Moldova's economic recovery is expected to be led by strong export growth, as the country regains the ground lost in traditional export markets following the Russian crisis 
of 1998, while also exporting more to other European markets. Moldova's recent accession to the WTO and membership in the Stability Pact for Southeastern Europe will help facilitating this process. Sustainable growth in the medium term is likely to come from the development of private activities in areas where the country has a comparative advantage. Moldova has a large agricultural sector, producing wine, tobacco, grains, fruits and vegetables. In addition, Moldova has a potential to develop light industries, based on relatively inexpensive but skilled labor, including agro processing and textile and leather industries. But achieving high and sustainable economic growth requires substantial investment, both public and private, and from both domestic and foreign sources. Foreign investment is particularly important not only to provide financing, but also to provide the much-needed transfer of new technologies and managerial skills. The following policies are key measures for attracting investment and reducing poverty.

66. Rationalization of public expenditures is necessary to improve social expenditure (education, health, and social protection) efficiency. In addition to reduced budgetary resources, the available resources are not efficiently utilized. In education and health, resources are mostly spent on higher education (university) and tertiary health care (hospital), reducing resources available for primary education and primary and emergency care that clearly benefit the poor. To properly design poverty focused social programs, the authorities also need to improve the quality of poverty data and social indicators to develop policies that better target the poor. A public expenditure management review (PEMR) by the World Bank that should help form the basis for making restructuring decisions in the social sectors is under preparation.

\section{Related to this aspect, establishment of an institutional and legal framework} appropriate for a market economy is needed. Although more favorable than some other poor CIS nations, bureaucratic controls, time-consuming approval procedures, corruption and harassment result in high costs of doing business. The investment climate remains difficult for the development of SMEs, mainly because of the persistence of discretionary administration of taxes and regulation. Laws on commercial companies, secured transactions, banking regulations, and other have been passed, and key reforms in the legal system, such as a market-friendly civil code and a modern bankruptcy law, are about to be put in place, to ensure that property rights are protected and contracts can be enforced. It is important that these laws are implemented in practice with adequate administrative and judicial support. Further steps will need to include the adoption of a market-oriented land code to facilitate the development of a land market and the reform of the judiciary.

\section{Many public and private firms have been plagued by low profitability,} accumulation of arrears (to the budget, to energy enterprises and to each other), and declining production and employment. While the loss of traditional markets and inadequate access to financial resources were important factors in creating this situation, poor corporate governance, inadequate management and poorly organized and outdated productive capacities were equally important. The re is an urgent need to realigning the production base of enterprises, especially the large loss-makers. In this regard, the remaining state-owned enterprises, notably in key economic sectors such as agro-processing, need to be privatized. 
The main obstacles to privatization are the drawbacks in the legal and administrative framework which directly affects the privatization process (notably, in year 2000 eight contracts for privatization were canceled) and political interference, particularly in the case of large enterprises such as in telecommunications and in electric power. In addition, implementation of the new law on bankruptcy, which provides for liquidation and restructuring through court-led proceedings, can further contribute to a reallocation of production factors to profitable venues.

69. Finally, Moldova's energy sector has undergone major positive changes in the past few years, which has resulted in the unbundling of Moldenergo, the former power sector monopoly, and the creation of ANRE, an independent energy regulatory agency. Three out of five power distribution companies have been privatized through the sale of a majority share to a strategic foreign investor, which introduced a new system of payment collection for electricity consumers in July 2001, including the ability to cut-off power supplies to non-payers. As a result, total collection ratios have increased dramatically over the last year and are now close to 90 percent, but only 30 percent are paid in cash. In 2000 , wide-spread and unfunded energy privileges were replaced by a targeted system of nominal compensations paid by the budget. Outstanding sector reforms include the need to privatize the two remaining state-owned distribution companies grids and its three power stations, as well as the hot water and heating supplier. Also, a large stock of (external) energy arrears remains.

\section{Regional Issues}

70. Transnistria. The conflict with the breakaway region of Transnistria has significantly affected Moldova. Moldova's heavy industries (a steel mill and a large electricity generating plant) are based in Transnistria. Also, smuggling via Transnistria has been widespread. To counter this, joint Moldovan/Ukrainian customs posts are to be opened along the border of Ukraine and Transnistria. The current government is actively trying to find a solution together with the international community to solve the conflict.

71. Southeastern European Cooperative Initiative. In June 2001, Moldova was the first CIS country to be admitted as a full member to the Stability Pact. One of the objectives is to establish free trade of goods between participating countries.

\section{Debt Sustainability and Strategies ${ }^{14}$}

72. Moldova's total external debt increased from virtually zero debt at the beginning of the 1990s to over $\$ 1.6$ billion (or 110 percent of GDP) at end-2000. This consisted of $\$ 1,024$ million in public and publicly guaranteed debt (72 percent of GDP), \$210 million in private debt, and $\$ 345$ in external energy arrears. The public and publicly guaranteed debt was contracted on only moderately concessional terms, and as a result the NPV of this debt

\footnotetext{
${ }^{14}$ See Appendix Tables 15a-b and 16a-b and Appendix Figure 4.
} 
was estimated at $\$ 967$ million at end-2000 (68 percent of GDP). More than half of the outstanding public and publicly guaranteed debt was owed to multilateral institutions, including to the Fund (\$154 million), the World Bank (\$289 million) and the EBRD (\$74 million). Debt owed to bilateral official creditors represented another 26 percent, including Russia (\$122 million), the United States (\$60 million), and Japan (\$29 million). The remaining 19 percent included a five-year $\$ 75$ million Eurobond (issued in 1997 with bullet repayment in 2002) and a number of direct and publicly guaranteed credits from foreign banks ( $\$ 114$ million). The NPV of debt-to-export ratio and the debt-to-central government-revenue ratio reached 139 percent and 380 percent, respectively, while the debt service on public and publicly guaranteed debt represented almost 40 percent of central government revenues, putting into question the capacity of Moldova to meet its current and future external debt service obligations in full, without seeking debt rescheduling and/or debt relief.

73. Debt service obligations currently absorb a high portion of government revenues, severely constraining the resources available for economic development and poverty reduction. The authorities' strategy to address the high debt burden consists of the following elements: (i) the continuation of tight fiscal policies, aimed at maintaining a primary budget surplus of about $1 \frac{1}{2}-2$ percent of GDP; (ii) earmarking privatization proceeds for servicing or retiring external public debt and clearing government wage arrears; (iii) refraining from new borrowing on non-concessional terms; (iv) where possible, using market-based methods to reduce debt; (v) improving the management of external and domestic public debt; and (iv) approaching creditors for debt restructuring.

74. Under the current program scenario, which relies on continued strong, but realistic, fiscal consolidation, sound monetary policy, and the implementation of structural reforms, as well as on the assumption that Moldova's external environment will remain favorable, Moldova's debt indicators will improve steadily over time to manageable levels. The NPV of future debt service obligations (public and publicly guaranteed, including financing gaps) would decline from its peak of 68 percent of GDP in 2000 to 22 percent of GDP in 2010. The NPV of debt-to-export and debt-to-revenue ratios are also expected to reach satisfactory levels by 2010, at 40 percent and 139 percent respectively. The debt service on public and publicly guaranteed debt would decline sharply to less than 10 percent of exports of goods and services and about 25 percent of central government revenues by 2010 .

75. However, while debt indicators point in the right direction over the long-term horizon (under good policies), the short-term situation looks problematic, particularly in terms of the sustainability of the fiscal position. The NPV of debt-to-revenue ratio is projected to remain above 250 percent until 2005. Under cautious assumptions regarding new concessional financing and privatization proceeds, Moldova faces severe liquidity problems in 2002-03, reflected by financing gaps of around $\$ 40-50$ million annually. To address this, Moldova will need to seek a restructuring of its debts to official and private creditors in early 2002, possibly on Naples terms. 
76. Under a low case scenario, where, even with good policies, the economic recovery takes longer to materialize due to external shocks, adverse weather conditions or a slower than expected private sector response to reforms, Moldova could easily become eligible for bilateral debt relief on highly concessional terms. Moreover, if an external shock would cause a sharp exchange rate depreciation, the country could suddenly face debt service ratios that would warrant debt relief. For example, under a low growth scenario, with real GDP assumed to grow at 2 percent annually, the NPV of debt-to-revenue ratio would remain above 250 percent until 2007, while external debt service obligations would continue to absorb between 30 and 50 percent of central government revenues throughout the next decade (over 7 percentage points more than under the base case assumptions). However, a rescheduling of commercial and bilateral debt on Naples terms would quickly bring Moldova's debt indicators below the thresholds established under the enhanced HIPC Initiative. 


\section{TAJIKISTAN-COUNTRY NOTE}

\section{A. Introduction}

77. Tajikistan is the poorest country of the former Soviet Union, with the lowest per capita income and the highest incidence of poverty. The reform process was delayed due to a civil conflict that only ended in 1997. Since then gradual progress has been made with regard to establishing a stable macroeconomic environment. Growth of GDP resumed in 1998 and during the past year inflation has moderated. As in other countries in the region, progress with the structural reform agenda has been mixed. Among the outstanding issues are reducing quasi-fiscal activities, accelerating the land reform process, completing privatization of large enterprises, and strengthen public sector institutions.

78. Absolute poverty is extremely high and undernutrition significant. Severe poverty (at $\$ 2.15$ per day) affects some 68 percent of the population, and over 95 percent are considered poor (below $\$ 4.30$ per day). Poverty has increased significantly during the transition, as a result of dramatic GDP decline and sharp increase in inequality. The government completed an Interim Poverty Reduction Strategy in October 2000, and is in the process of preparing a full-fledged PRSP. The interim strategy focuses on labor-intensive growth, provision of basic social services, targeted income support for the poor, and improved governance and security, as main instruments to fight poverty.

79. The current macroeconomic outlook is one of moderate growth, price stability and a reduction in the current account and fiscal deficits. Growth is projected to slow from 6 percent in 2002 to 3 percent in 2010, as the aluminum smelter reaches its full capacity and as productivity gains from ongoing structural reform are fully realized. Export growth is projected to average 6 percent annually while imports are projected to increase by a little less, leading to a gradual reduction in the current account deficit.

\section{B. Priorities for Future Economic Growth and Poverty Alleviation}

80. Growth in the near term is expected to originate mainly from agriculture and light manufacturing as a result of increasing agricultural productivity due to farm privatization, and an expansion of agro-processing and other manufacturing capacity. Achieving even moderate levels of sustainable growth and poverty reduction will require macroeconomic stability, supported by an acceleration of structural reforms, including a significant reduction of quasi-fiscal deficits, especially in the energy sector and a more friendly environment for private activity with an emphasis on improved governance. While the government has prepared a Public Investment Program (PIP), implementation will likely be slow because of the limited absorptive capacity of the country.

81. Sustainable medium-term growth will require macroeconomic stability and a more efficient foreign exchange market. With tighter monetary policies and a projected increase in money demand as confidence in the currency and the banking system increases, inflation is projected to decline from almost 40 percent in 2001 to an average of 5 percent per annum in the medium term. While there would be some fiscal consolidation, the narrowing 
of the large current account deficit over the projection period would be achieved mainly through an improvement in the savings and investment balance of the private sector. Also, the current interbank foreign exchange market, while an improvement over the previous system, still needs further liberalization.

82. Raising fiscal revenues is a major priority. The tax collection rate, which was 9 percent below the regional average of 23 percent of GDP in 2000, needs to be raised over the medium term. This could be achieved in the immediate term through stronger tax administration efforts via a reorganization of the Tax Committee and the tax police, with governance-related problems addressed by a restructuring of the tasks of these two agencies, and in the medium term through reforms of the tax code.

\section{Reforms in the social sectors are expected to boost productivity and support} economic growth. While Tajikistan's educational and health standards have declined since independence, the country still has a good human capital base. Recent pilot reforms show some improvement, and the Poverty Reduction Strategy Paper (PRSP) process has added new awareness of the need for social sector reforms. The next phase of reforms need to focus on effective prioritization of social expenditures through the preparation of a medium term expenditure strategy and a redefinition of the role of key ministries in a market economy context. Better expenditure control is also envisioned through the recent extension of treasury coverage to all central and local government transactions and setting up of regional treasuries in the remaining districts, the pending adoption of the draft treasury law, and the implementation of expenditure commitment control measures in all spending ministries.

84. To increase productivity, the privatization and subsequent restructuring of medium- and large-scale enterprises as well as of state-owned and collective farms needs to be accelerated. While the government has sold all the state-owned cotton ginneries, and small-scale privatization is largely completed, only one third of the medium and largescale SOEs have been privatized so far. The largest industrial companies, including the aluminum smelter, energy companies, and all other utilities, remain state-owned. By sector, while a large number of enterprises in the trade and services sectors have been privatized, those in construction, transport, communications, and agriculture remain predominantly state-owned. Progress on restructuring is also behind that achieved in other CIS countries, although industrial growth has been relatively broad in recent months, suggesting privatization has impacted positively business performance. To promote restructuring in small, medium, and large enterprises, the government needs to overhaul its bankruptcy legislation, increase creditor rights, and introduce basic shareholder rights protection. Significant assistance to the legal system will be required to make these rules enforceable. Above all, there is a need for political will to deal with public enterprises on an arms- length basis, official support to soften the social consequences of restructuring, and a sustained effort to improve financial and management performance.

85. Improving agriculture policies is also necessary. Agriculture plays a vital socioeconomic role in the economy and especially in the lives of the poor. Improving agricultural productivity and promoting rural growth represent the most important element of any 
strategy for poverty reduction. A pro-poor agricultural strategy requires development of markets and market institutions, improved access to land (including through privatization), and rehabilitation of rural infrastructure, especially irrigation. Between 20 and 30 percent of arable land is presently not in use because of the breakdown of the irrigation and drainage systems. Public intervention in the agricultural sector also needs to be reduced.

86. To reduce quasi-fiscal deficits, which are estimated at 7 percent of GDP in the energy sector alone, electricity and gas tariffs need to be raised and collection rates should be improved, in particular from the industrial sector. Tajikistan does not have active oil and gas reserves, although it has rich hydroelectric power resources. While Tajikistan aims to become fully self-sufficient through the completion to two further hydropower projects, there are doubts over their economic viability and the adverse consequences for irrigated agriculture downstream in Uzbekistan and Turkmenistan. The state owned power company controls all power gene ration, transmission and distributions, and Tajikistan has introduced little reform in these critical areas relative to the other poor CIS nations. Electricity tariffs are still at only about one-third of cost recovery levels and non-collection of charges for power and natural gas amounted to almost 4 percent of GDP in 2000 with another 2 percent of GDP in provisions for bad debts from previous years. A new energy law was approved in October 2000, leading to the creation of an energy ministry with the role of formulating policy. While affordability issues need to be considered carefully, adjustment towards cost-recovery levels is essential if the long-term potential is to be realized.

\section{Weak administrative capacity has led to repeated concerns over governance} issues. The business climate remains difficult in Tajikistan especially for SMEs and new entrants, and FDI remains low. The main reasons are lack of access to finance, weak public administration and governance, and significant internal market barriers. The problems with governance relate to weak state capacity, with local interest groups exerting considerable influence, and also the prevalence of conflicts of interest within key government positions. An intensification of the auditor general's activities could enhance governance and improve the environment for the private sector. The establishment of the Anti-Monopoly and Entrepreneurship Support Agency would also support small- and medium-scale enterprise development.

88. Finally, improvements in the capacity of the banking system to mobilize domestic savings could be achieved by implementing the existing restructuring plans for the four largest commercial banks. Adopting a law eliminating the obligations of commercial banks to report automatically information on new deposits to the Tax Committee would also assist in this effort.

\section{Regional Issues}

89. Being a landlocked country, Tajikistan's external transport links are controlled by neighboring countries and have been subject to sudden closure. While there have been discussions to harmonize regional transport arrangements under the Customs Union program, these have not yielded tangible results and it is not clear when and how transport 
arrangements will be agreed upon. Because of the significant regional water and energy management issues, the long-term development of the energy sector relies on a regional agreement.

\section{Debt Sustainability and Strategies ${ }^{15}$}

90. Under the baseline scenario, the net present value of Tajikistan's debt falls below 250 percent of government revenue by 2008 (Appendix Table 17a). In the short term, however, the share of debt service payments is equivalent to 50 percent of government revenues in 2002 and averages 37 percent through 2008. Flow rescheduling of Tajikistan's debt on Naples terms would alleviate this burden during the consolidation period, but to achieve fiscally sustainable debt service obligations in the medium-term, a stock-of-debt rescheduling on Naples terms would be necessary.

91. Under the low-case scenario, where GDP and export growth are projected at about 2 percentage points lower than under the base case, the net present value of Tajikistan's debt would remain above 250 percent of government revenues throughout the projection period. Debt service would require almost half of central government revenues. Indeed, debt service obligations would remain above 17 percent of government revenue regardless of rescheduling arrangements (Appendix Table 17b). Hence, while it is possible for Tajikistan's external debt to become fiscally sustainable in the medium term through moderate growth (under the baseline) based on structural reform, the debt service burden as a share of budget revenues would remain unacceptably high. A stock of debt restructuring would reduce the latter burden significantly. Without sustained growth in GDP (the low case), however, the debt burden would not become fiscally sustainable in the foreseeable future.

${ }^{15}$ See Appendix Tables 17a-b and 18a-b and Appendix Figure 5. 


\section{AZERBAIJAN-COUNTRY NOTE}

\section{A. Introduction}

92. After a steep economic decline following the break-up of the Soviet Union, Azerbaijan's economy has grown at a rapid pace since 1997. Initially this growth was mainly driven by the oil and gas sector, but in 2000 and 2001 growth has been strong across the board, including in agriculture. Small-scale privatization is nearly complete. Medium and large-scale privatization was re-launched with the adoption of the Second Privatization Program in August 2000, with some 450 larger enterprises offered for privatization in March 2001 (including telecom, fuel and energy enterprises and the state-owned airline AZAL).

93. Poverty remains pervasive. In 2000 , per capita GDP stood at $\$ 652$ per year, and the distribution of income is highly unequal. For example, in 1999 wages in the oil and gas extraction sector were on average ten times higher than wages in agriculture. Azerbaijan's Interim Poverty Reduction Strategy Paper (I-PRSP) put the number of people living on incomes below the poverty line at 61 percent.

\section{B. Priorities for Future Economic Growth and Poverty Alleviation}

94. The challenge for Azerbaijan is to maintain its strong macroeconomic performance, while making economic growth more inclusive. As the oil and gas sector further develops, it will be important to create a business climate that promotes sustainable growth in other sectors of the economy. The construction, transport and service sectors are especially likely to benefit directly from the development of the oil and gas sector. Other sectors of the economy, especially agriculture, are not likely to experience 'linkage' effects. The recent strong performance of the agricultural sector can be attributed to structural reforms, such as the land reform process that took off in 1997, and the dissolution of state monopolies in the sector. However, the lack of rural credit remains an important bottleneck, and the irrigation system is in need of rehabilitation and modernization. Four major obstacles stand in the way of sustained growth in Azerbaijan's non-oil and gas sector: governance and corruption, poor targeting and low efficiency of social expenditure, inadequate infrastructure, and weak energy sector policies with respect to domestic consumption.

\section{As the county has evolved toward a market economy, poor targeting and low} efficiency of social expenditure have not reduced poverty. The current system frequently spreads low benefits among a large number of recipients. The lack of regular and comprehensive data on living standards has prevented the definition of an appropriate poverty line and posed difficulties for enhancing targeting social protection programs. The government had already taken steps to improve poverty monitoring and intends to update the poverty profile based on revised surveys on household living standards. The poverty profile is critical background information for completing PRSP preparation and should be updated annually. The government is also working on a medium-term strategy for enhancing 
targeting of social assistance and alleviating the impact on the poor of higher tariffs on public utilities.

96. Public sector reforms aimed at improving targeting and efficiency of social expenditure are essential for reducing poverty. The government is committed to work out and implement a medium-term strategy for enhancing the targeting of social assistance programs. As part of this strategy and efforts to strengthen financial discipline in the energy sector, the government has replaced the system of privileged tariffs for selected groups with explicitly targeted subsidies. It is seeking to eliminate the substantial untargeted subsidies now provided implicitly through low prices and tolerance of non-payments. In its place, the government will consider the available options, including the possibility of lifeline tariffs (fixed amounts of power at subsidized levels).

97. The government is also committed to improve the budgetary process and the overall public expenditure management, so as to ensure adequate budget allocation for the social sectors. With the enactment of the new Budget System Law and the development of a Medium Term Expenditure Framework (MTEF), the government will ensure that (i) policies or priorities focusing on poverty reduction are explicitly linked to the budget; (ii) the budgetary process is sound, and budgetary planning and execution is policy oriented; (iii) there is a predictability of both policy and funding so that line ministries can plan ahead and programs can be sustained; and (iv) line agencies are provided with a hard budget constraint and increased autonomy, thereby increasing incentives for efficient and effective use of funds.

98. Expenditures on health and education are characterized by major inefficiencies, including overstaffing, and have resulted in a drastic reduction in the quality and access of the poor to these services. Regarding education, enrolment rates are lower among the poor, and poor children are more likely to have prolonged absences from school. Regarding the accessibility of health services, the evidence from social assessments and household surveys suggests that much of the improvement in health indicators is due to non-reporting, as the poorest households are increasingly not using public health facilities.

99. Reform of domestic energy sector policies could greatly enhance the availability of energy sector receipts for targeted spending aimed at poverty reduction. Energy consumption in Azerbaijan is highly inefficient because of under pricing and tolerance of non-payment by end users of electricity and gas. Quasi-fiscal subsidies related to domestic energy sector policies originate from three main sources: (i) revenue losses by SOCAR from charging below market prices for fuel oil and gas supplied to Azerenergy and Azerigaz (the state-owned utilities responsible for electricity supply and heating); (ii) low collection rates by final users - only 44 percent of gas and 41 percent of power supply billings were collected in 1999 and several groups of the population were exempt; and (iii) technical losses and theft. Given that payments continue to be a problem, it will be crucial to privatize distribution companies and ensure improved metering and collections prior to moving ahead with privatization of power generation companies. The authorities have developed a comprehensive program to resolve these problems, including tighter budgetary control of 
utilities, a schedule for the eventual unification of the low domestic to the exported oil price, and privatization of all distribution networks. It will be important to ensure that an appropriate regulatory framework, including cost-recovery tariffs, is in place to attract serious strategic investors.

100. The government of Azerbaijan has recently taken encouraging steps to improve governance. Weak governance has been one of the most frequently-mentioned factors that has adversely affected the investment climate in Azerbaijan. It is a major obstacle to enterprise-led growth, stifling the entry and expansion of enterprises based on superior competitive performance, and distorting the allocation of resources from productive to rentseeking activities. A Chamber of Accounts (supreme audit institution) that has the right to audit all government bodies has now been made operational. An audit by a respectable international auditor of the Customs Committee is now underway. In addition, the government has set up an Oil Fund for the management of its oil revenues, and has put in place strict rules for the transparent management of this Fund. However, much more will need to be done. For example, a clearer separation of regulatory and commercial functions of state enterprises could improve governance. Tax administration will need to be modernized to reduce opportunities for corruption. Increased government spending on health and education should make access to these essential services less dependent on current ad hoc user 'contributions'.

\section{Policies that would improve the business environment and enhance private} sector development are critical to job creation and poverty reduction. The development of SMEs and non-oil and gas investments is severely constrained by a poor investment climate, lack of finance, and inadequate infrastructure. The government should promote investments in these sectors, especially in SMEs in the agribusiness sector. The legal basis for a market economy has been introduced based on the new constitution and reforms in the legal system. The new tax code lightens the burden and injects objectivity into the tax regime. The government is committed to conduct a survey which would identify administrative barriers to private sector entry and measure future progress in their elimination. Important policy reforms aiming at minimizing corruption and conflict of interest in the business environment are: (i) separating commercial from policy and regulatory functions in the energy sector, and establishing a firm schedule for tariff policy reform; (ii) reviewing the licensing regime with a view to reducing the number of licensing activities; and (iii) addressing corporate governance issues, which often greatly impede private investment, and especially foreign direct investment, through requiring international accounting standards (IAS) in financial and oil sectors. All joint stock companies over a threshold level of turnover would also be required to produce accounts in line with IAS from 2002, as well as making the annual report including the accounts publicly available.

\section{Strengthening of domestic financial markets should also be a priority for the} government. Economic growth since 1997 has been financed to a large extent by foreign investment, but the non-oil sector cannot rely on this source of credit. The government needs to move aggressively in privatizing the remaining majority state-owned banks, International Bank of Azerbaijan and United Universal Bank, thus contributing to the establishment of a 
level playing field in the banking sector. The government should also improve its own capacity for attracting credit by developing the treasury bill market. The National Bank has recently conducted a study of the factors inhibiting competitiveness in the banking sector, and is in the process of preparing a plan to address these factors.

\section{Regional Issues}

103. Azerbaijan does not have direct access to the international oil market. At present, the country uses two export routes to the Black Sea. The Western route takes crude oil through Georgia to Supsa, and the Northern route transits oil through the Russian Federation to Novorossiisk. The planned Baku-Tbilisi-Ceyhan pipeline will take Azerbaijan's oil to the Mediterranean via Georgia and Turkey. Continued good relations with Georgia, Russia and Turkey will be essential to ensure the success of the planned oil and gas sector projects.

104. Regional conflict has negatively effected Azerbaijan's economic development since independence. The conflict with Armenia over the status of Nagorno-Karabakh remains unresolved. In addition, disputes over the division of the Caspian Sea among the five littoral states could delay development of the oil and gas sector or even lead to military conflict. Any renewed regional political instability could divert attention and resources from pressing social and economic reforms.

\section{Debt Sustainability and Strategies ${ }^{16}$}

105. Azerbaijan's external debt amounted to 23 percent of GDP in 2000, and is projected to remain at around 25 percent of GDP over the medium term. Over 90 percent of the 2000 stock of debt of about $\$ 1.2$ billion was owed to official creditors, with the IMF and the World Bank together accounting for over half the stock of this debt. All of Azerbaijan's external debt has medium or long term maturity. External debt service in percent of the export of goods and services was 4.4 percent in 2000 and is projected to remain below 10 percent in the medium term. At these relatively low ratios, the extent of Azerbaijan's external debt does not seem to pose a serious impediment to economic growth and poverty reduction.

${ }^{16}$ A baseline macroeconomic forecast and summary data on the stock of debt are shown in Appendix Tables 19 and 20. 


\section{UZBEKISTAN-COUNTRY NOTE}

\section{A. Introduction}

106. Uzbekistan adopted a gradualist approach to transition. According to official statistics, Uzbekistan had the smallest decline in output of all the CIS countries since the dissolution of the Soviet Union and achieved self-sufficiency in wheat and energy by the mid 1990s. However, the reversal of the initial foreign exchange and trade liberalization measures, the introduction of multiple exchange rates together with restrictions on current account transactions, and the pursuit of import-substituting industrialization policies since late 1996, have constrained economic growth. A number of macroeconomic imbalances have persisted, and external debt accumulation to finance growth has been high until recently. In particular, over the past five years, high spreads between the official and curb market exchange rates, combined with export surrender requirements, placed a heavy tax on exports that was used to subsidize imports of capital, raw materials, and priority consumer goods. In addition, tight administrative restrictions on trade (through the restrictive foreign exchange regime) were maintained in order to protect the domestic industry from external competition. Financial policies have also been used to promote priority industries, mainly through the extensive use of directed credits and government-guaranteed loans. Interest rates have been kept negative in real terms. General government budget deficits (excluding quasi- fiscal activities), however, have been contained to help control monetary expansion. The current account deficit has been restrained by severe import compression working through a mix of non-tariff barriers and foreign exchange and trade restrictions. Government policies have resulted in large net resource transfers out of agriculture, suppressed rural incomes, and greatly exacerbated the rural urban income divide. Structural reforms have been limited, despite numerous government resolutions, and have so far failed to adequately address fundamental distortions in the incentive structure or improve the business environment.

107. Uzbekistan was one of the poorest republics in the Soviet Union, with the distribution of poverty showing a strong rural bias, and since the dissolution of the Soviet Union, pove rty has by all indications increased. The results of the first comprehensive assessment of national living standards are still being analyzed, but the evidence from other recent studies consistently suggests poverty rates of between 20 and 30 percent. The low levels of per capita income, combined with a large inequality in distribution (e.g., the Gini coefficient for consumption is 0.4 in Fergana oblast), have contributed to relatively high poverty rates. The depth of poverty is quite significant: average expenditures of the poor are approximately 38 percent below the poverty line. Rural poverty continues to be significant and the rurat urban divide may have widened. There are also considerable regional disparities in poverty levels. Households in the northwest of the country (Karakalpakstan and Khorezm) as well as Kashkadarya and Namangan have significantly lower standards of living than those in Tashkent city and oblast and, to a lesser extent, the Fergana valley (Andijan, Fergana). The lower-income areas are also indicated by below-average health outcomes. There is increasing evidence that quality of life is deteriorating, especially among the poor. Generating employment for an increasingly young population poses a serious challenge. 
108. The social protection system in Uzbekistan has been relatively more effective than in some other countries of the region in targeting benefits. However, these benefits are inadequate to protect the most vulnerable from poverty: unemployment benefits, social assistance, and child allowances stood at 3 percent of GDP in 2000. The lower poverty rates among pensioners suggest that the pension system has been successful in reducing old age poverty, albeit at a high cost. Pension spending is 7-8 percent of GDP and tax rates to finance pensions represent almost 40 percent of payroll, with the result that the pension system is caught in a low compliance-high contribution rate trap.

\section{B. Priorities for Future Economic Growth and Poverty Alleviation}

109. Uzbekistan's medium-term prospects depend cruc ially on the ability and/or willingness of government to reduce macroeconomic imbalances and to liberalize the economy to create the necessary conditions for accelerated private development and export growth. With consistent progress towards a more market-oriented foreign exchange regime, including the lifting of restrictions on access to foreign exchange for enterprises and individuals and other priority reforms, Uzbekistan's economy could achieve broad-based, export-led real GDP growth of up to 5 percent per annum over the medium term.

110. In particular, the cotton sector, which accounts for the bulk of agricultural exports, would enjoy important price incentives to increase productivity should there be an elimination of the state order system which artificially holds producer prices down. Farmers growing other crops as well as fruits and vegetables for export, would also be beneficiaries. Growth performance in the industrial sector would be more differentiated. Some industrial sectors - those dominated by less efficient large-scale enterprises, many of which have been supported by implicit subsidies through the multiple exchange rate regime-would contract. However, industrial exporters and potential new entrants, including foreign investors that have been discouraged by the overvalued exchange rate, tight regulations, and unfriendly business climate, would receive a growth stimulus. The energy sector, especially oil and gas, and chemical processing industries, have a high potential for increasing exports and becoming growth leaders within the industrial sector provided their output prices are raised to full cost-recovery levels. The improvement in the business environment, lifting of restrictions on cash circulation, and spill-over of growth from agriculture and export-oriented industries, would also boost activities in the tertiary service sector, and support a broad-based reduction in poverty.

\section{Turning to policy specifics, the restrictive exchange rate regime remains a key} obstacle to economic growth in Uzbekistan. Despite the administrative unification of the official and OTC exchange rates in November 2001, which together with other measures during 2000-01 reduced the scale of implicit taxation and subsidization through the exchange rate regime, Uzbekistan still has two legal exchange rates: the official/over-the-counter ${ }^{17}$ rate

${ }^{17}$ The over-the-counter exchange rate is in theory market determined, but in practice is heavily managed by the authorities. 
and the exchange bureau rate with a margin of about 20 percent between them. The illegal curb market rate has continued to depreciate, and the curb market premium relative to the OTC rate remains substantial (more than 100 percent in December). Access to foreign exchange is restricted by quotas ("import projections"), import contract registration requirements, and limits on the amount of foreign exchange to be sold to consumer goods importers. All exports, except those of small and medium enterprises exporting their own products, are subject to heavy mandatory foreign exchange surrender requirements. The foreign exchange regime liberalization measures should involve: (i) elimination of any quotas, ex-ante import contract registration requirements, and limits on the purchase of cash foreign exchange, as well as an easing of documentation requirements on access to both the legal cash foreign exchange and OTC markets; (ii) unification of all exchange rates and adoption of market-oriented policies that will substantially narrow and finally eliminate the gap between the unified official and curb market exchange rates; and, associated with this, (iii) easing of mandatory surrender requirements for some or all centralized exports (mainly gold and cotton), and elimination of the mandatory surrender requirement for other exports.

\section{Agricultural policies need to be more oriented toward those of a market}

economy. Government control over the production decisions and output prices through the state order system for wheat and cotton, and the foreign exchange surrender system for cotton exports, implicitly tax farmers heavily and are estimated to more than offset the size of the subsidies provided to agriculture. State procurement prices for wheat and cotton have consistently been below world market levels. For instance, the state procurement price in 2001 is only around 40 percent of the "fair" market price at the OTC rate. The net effect of the agricultural policies was an annual transfer of an estimated 4-5 percent of GDP out of the sector during 1996-98. This transfer of resources is a major cause of rural poverty in Uzbekistan, and, in addition, severely constrains general economic growth in the rural areas. It hinders the introduction of adequate irrigation and utility charges, and thus reduces the efficiency of allocation and conservation of resources. Not only is there a transfer of resources through this implicit taxation of the agricultural sector, but there is also a loss in productivity that comes from procurement price disincentives. The output value per hectare - and therefore potential incomes — of dekhan farmers (household plot farmers), who are subjected to less onerous requirements on mandated areas under strategic crops (cotton and wheat) for state orders, are several times higher than that of cooperatives (shirkats). Priority reform measures should include: (i) setting state procurement prices of cotton and wheat at world market levels at the market exchange rate (accounting for processing and transport costs); (ii) replacing the state order system, including mandatory production patterns, production targets, and administratively-set prices, for cotton and wheat by a procurement system under which there is no interference with farmers' production decisions and mandatory sales to the state; and (iii) privatizing majority stakes in cotton ginneries and liberalizing export procedures for such ginneries.

\section{Elimination of restrictions on the use of cash and improvement of the business} climate is also a priority. Business development, particularly that of small and medium sized enterprises, in Uzbekistan is hampered by the existing restrictions on cash circulation and the unfavorable business climate that has discouraged foreign investors. Enterprise 
restructuring is lagging due to convertibility restrictions, distorted relative prices, and state associations' dominance in marketing, procurement of input, and poor corporate governance. Although explicit budget subsidies to state enterprises have been largely eliminated, implicit subsidies are large, and interference through foreign exchange allocation persists. Improvement in the business climate in the short term requires: (i) elimination of restrictions on cash usage by individuals and enterprises except for diligence reporting on very large cash transactions by commercial banks; and (ii) elimination of directed credits and liberalization of interest rates on bank loans.

\section{Privatization of medium- and large-sized enterprises is proceeding with mixed results, largely on account of the unfavorable business climate and inadequate} government commitment. While the government has ambitious plans for divesting its stakes in large strategic enterprises (including the largest associations), it has made little progress to date. Major areas for privatization include the energy sector-recently restructured into eight separate entities - the banking sector, and some large metallurgical companies. It will be necessary to change the approach to privatization, including offering controlling stakes for privatization to both domestic and foreign investors.

\section{Improvements in energy policies, including pricing policies, are necessary.} Uzbekistan is self-sufficient in oil and natural gas, but the Uzbek electricity system is a high cost operation. Uzbekenergo has recently been corporatised, providing the basis for privatization. However, at this stage an independent regulator does not exist, and tariff policy is largely executed by the Ministry of Finance. Indeed, since 1997 there have been few tariff increases. The result has been a large decline in cost recovery levels in the electricity sector and insufficient financial resources to maintain power plants and transmission lines. Large implicit subsidies to the economy through underpricing of natural gas and petroleum have contributed to a deterioration in the financial condition of the power sector as well. Reforms should involve: (i) an immediate increase in the electricity tariffs, natural gas, and oil prices; and (ii) a tariff policy that achieves cost recovery in the energy sector over the medium term, providing clear rules for the future adjustment of tariffs, and administered by an independent regulatory agency.

\section{Regional Issues}

116. In recent years, water management, transportation, and regional trade barriers have emerged as key regional issues of importance to Uzbekistan. The lack of coordination in water management with Tajikistan and the Kyrgyz Republic have resulted in occasional water shortages in Uzbekistan during the agricultural season. As a land-locked country, Uzbekistan must secure an unhampered, reliable, and affordable access to transportation networks of Kazakhstan, Turkmenistan, and Russia for access to world markets. At the same time, Uzbekistan also needs to further facilitate transit through its territory by exports from Tajikistan and parts of the Kyrgyz Republic which are dependent on Uzbekistan's road and railway networks for access to the outside world. Regional trade and access to world markets of the Central Asian countries are also hampered by disparate trade regimes and various nontariff barriers. 
117. The resolution of these regional issues is a prerequisite for sustainable economic growth in Uzbekistan. In recent years, Uzbekistan has given preference to a bilateral approach in addressing these issues. However, finding multilateral, long-term solutions is likely to be the most efficient way to achieve a stable economic environment and boost economic growth in the region. Given Uzbekistan's strategic location ${ }^{18}$ and the size of its economy, its participation is crucial for the success of any regional initiative.

\section{Debt Sustainability and Strategies ${ }^{19}$}

118. External debt has increased substantially through 1999 before leveling off at around $\$ 4.3$ billion, but debt service in 2000 ( $\$ 0.9$ billion) was already three times larger than in 1996. At the same time, exports have fallen by over 16 percent (in value terms) since 1997. As a result, Uzbekistan's debt indicators have deteriorated: in 2000 the external debt-to-exports ratio and the external debt service ratio stood at 130 percent and at 28 percent. Moreover, given Uzbekistan's reliance on commercial borrowing, the present value of Uzbekistan's external debt is close to its face value. The fiscal burden of debt is also potentially high: public and publicly guaranteed debt service as a share in consolidated government revenue is about 25 percent at the OTC rate. Since a large part of the debt has been incurred by financially non-viable state enterprises under government guarantees, there is a distinct possibility that the budget might have to service these obligations. In addition, debt has increased despite the external current account surplus and stable reserves, indicating substantial capital outflows. Although external factors (low world prices for gold and cotton, droughts) have played a role in the debt build-up, domestic policies were a key factor: as noted above, the current agriculture and exchange rate policies discourage exports and create incentives for capital flight.

${ }^{18}$ Uzbekistan has common borders with all the other Central Asian countries.

${ }^{19}$ A baseline macroeconomic forecast and summary data on the stock of debt are shown in Appendix Tables 21 and 22. 
Appendix Figure 1. Armenia: Debt Sustainability, 2000 - 2010

NPV of debt service

(In percent of exports of GNFS)

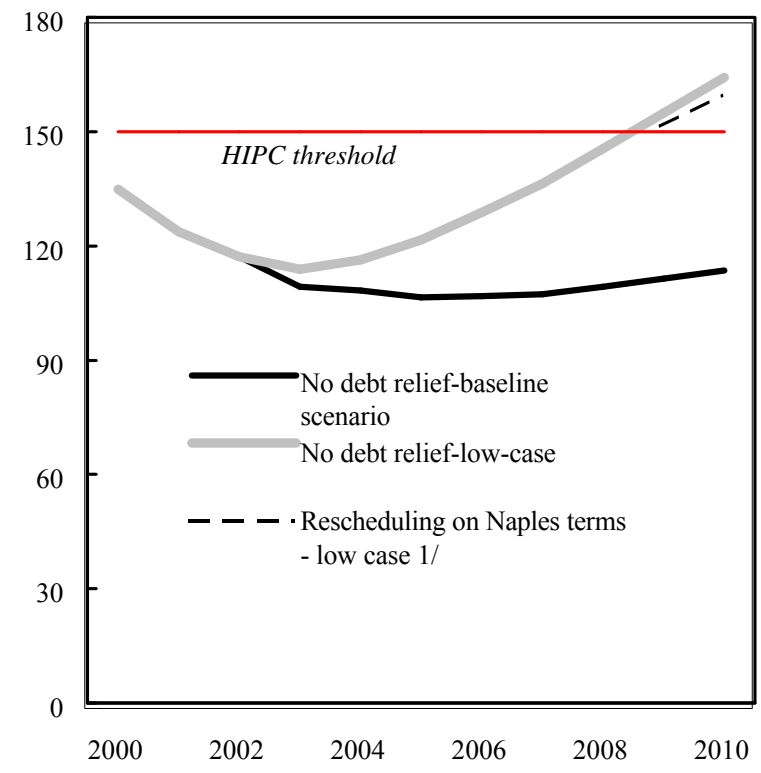

Debt service

(In percent of exports of GNFS)

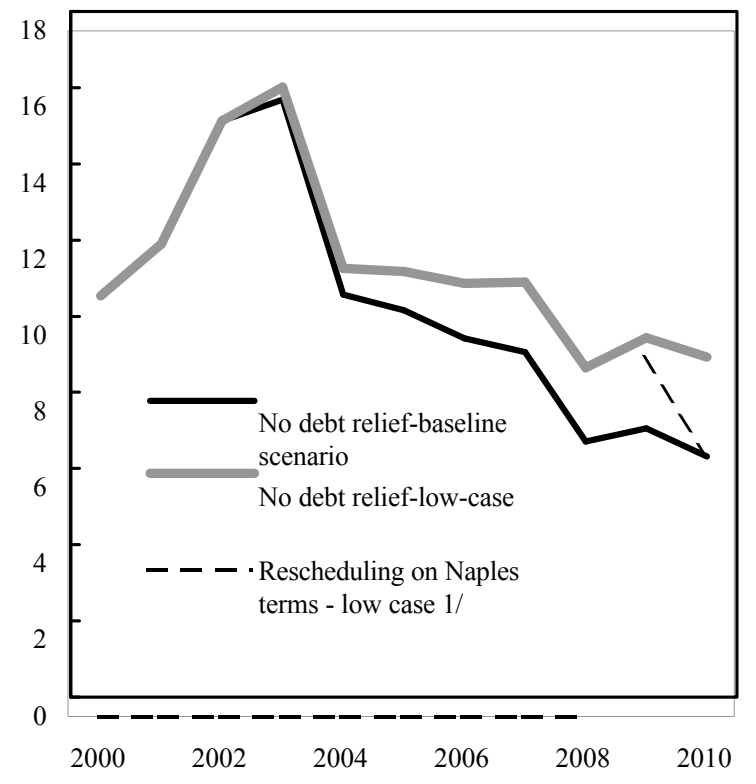

NPV of debt service

(In percent of government revenue)

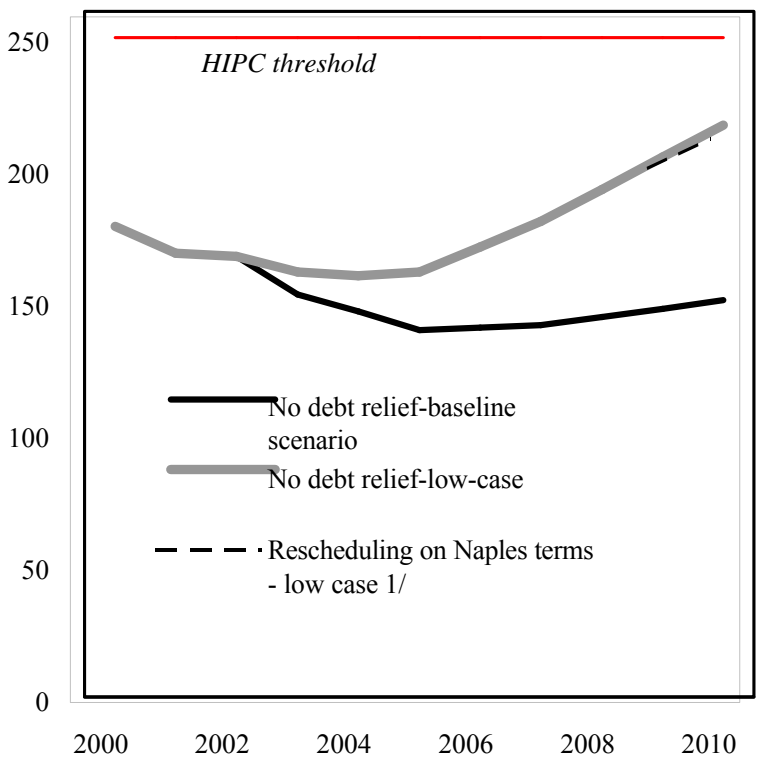

Debt service

(In percent of government revenue)

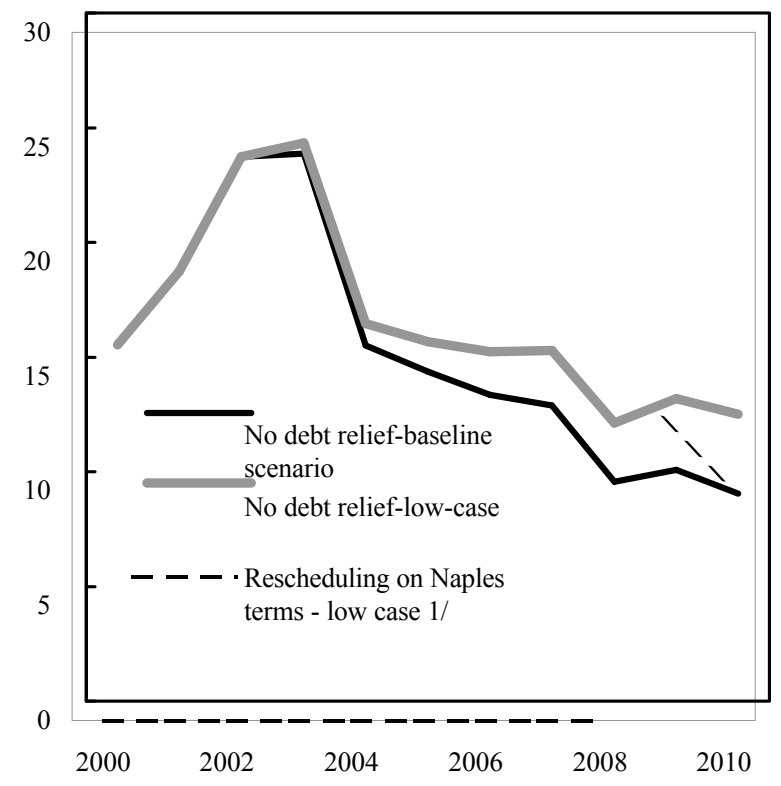

Source: Staff projections

1/ Flow restructuring in 2009. 
Appendix Figure 2. Georgia: Debt Sustainability, 2000 - 2010

NPV of debt service

(In percent of exports of GNFS)

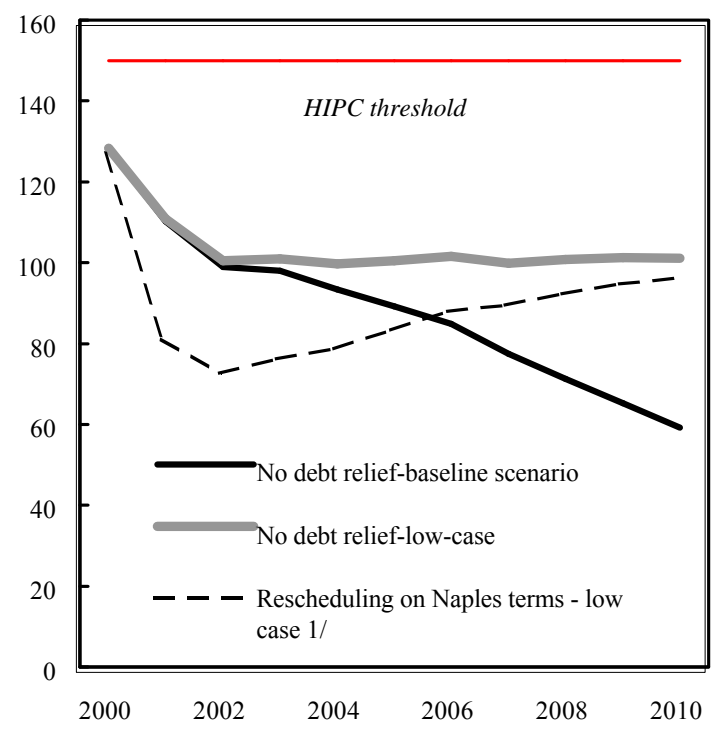

Debt service

(In percent of exports of GNFS)

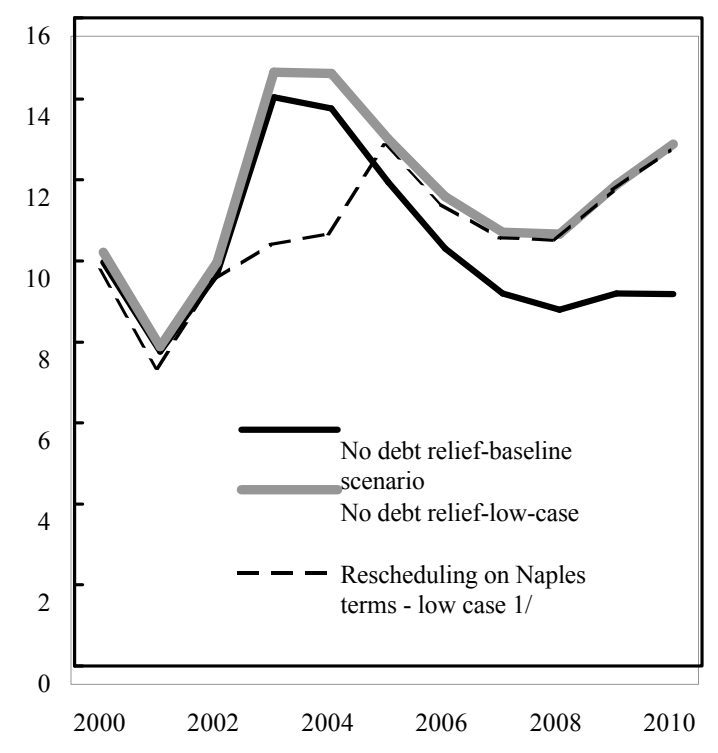

NPV of debt service

(In percent of government revenue)

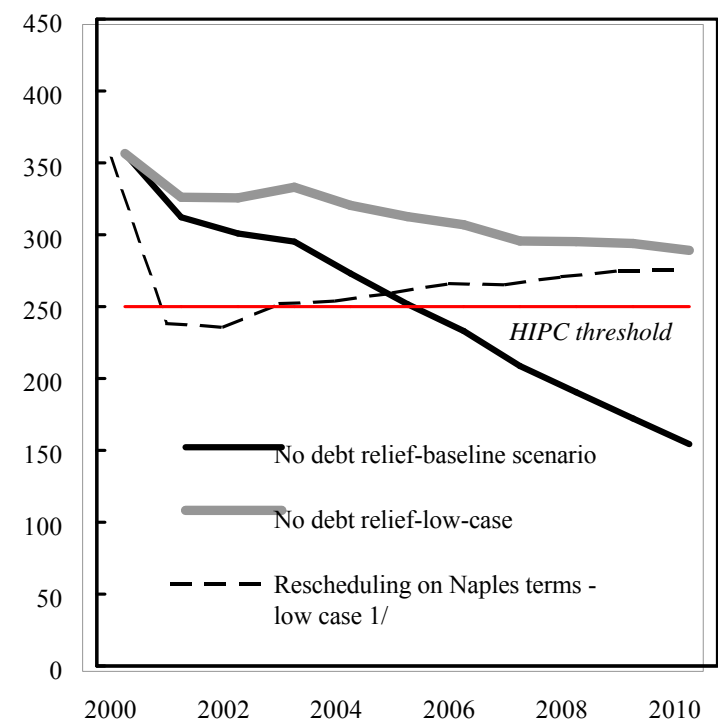

Debt service

(In percent of government revenue)

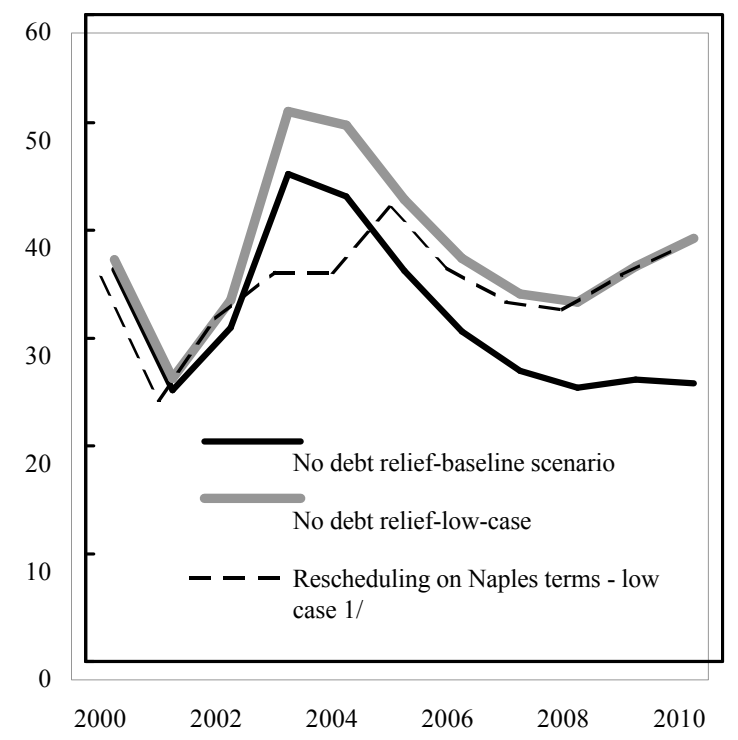

Source: Staff projections

1/ Stock restructuring in 2001. 
Appendix Figure 3. Kyrgyz Republic: Debt Sustainability, 2000 - 2010 1/

NPV of debt service (In percent of exports of GNFS)

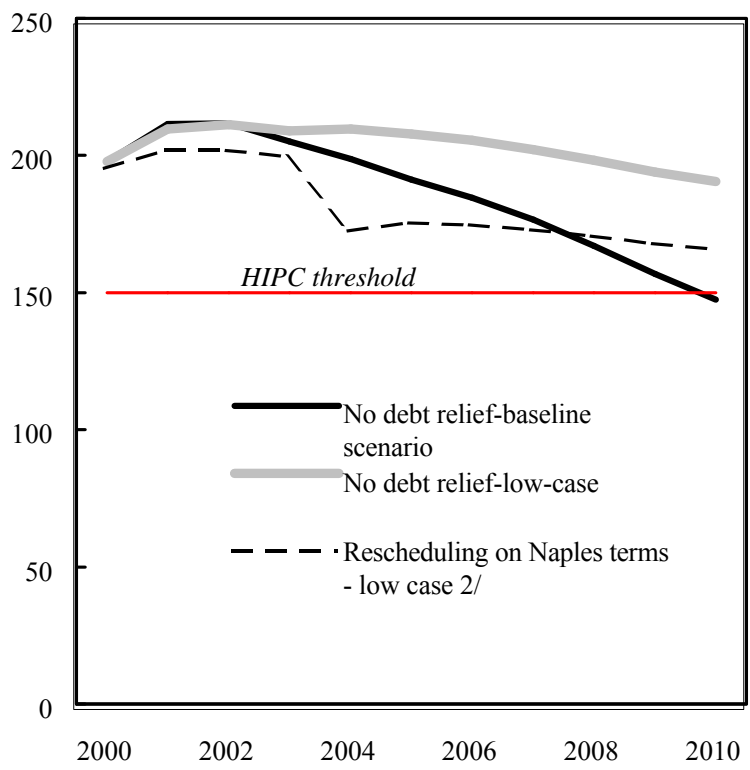

Debt service

(In percent of exports of GNFS)

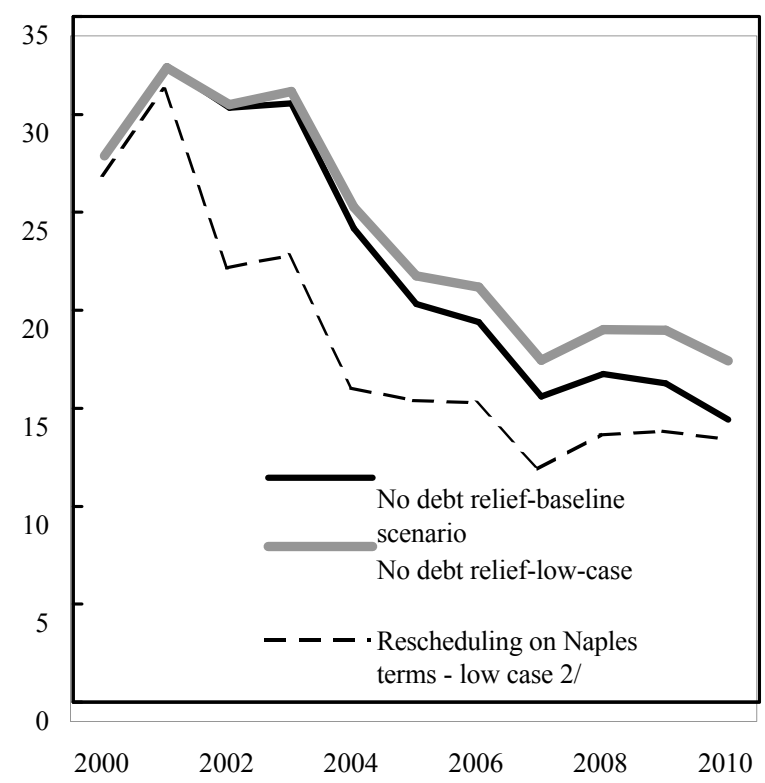

NPV of debt service

(In percent of government revenue)

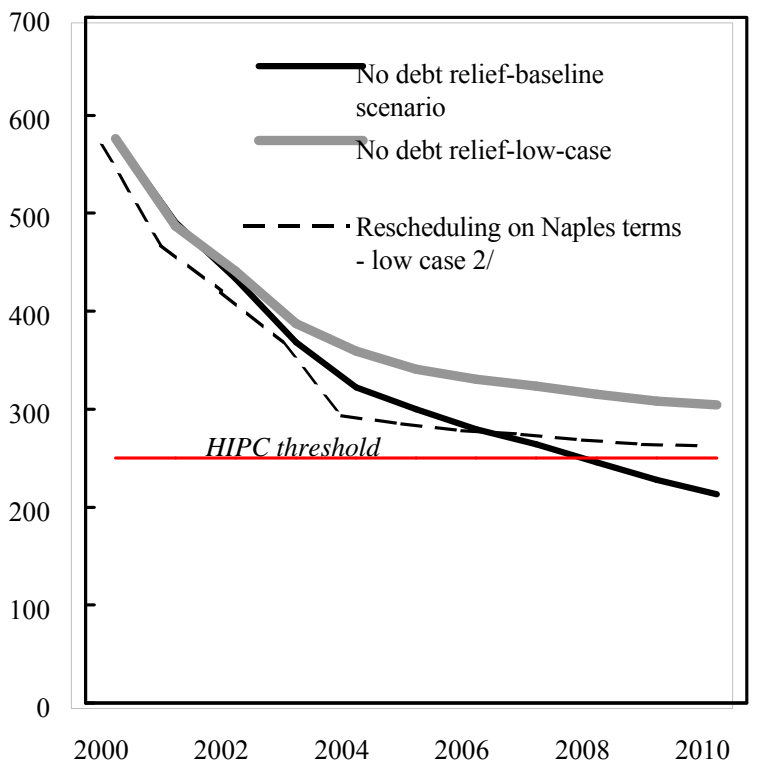

Debt service

(In percent of government revenue)

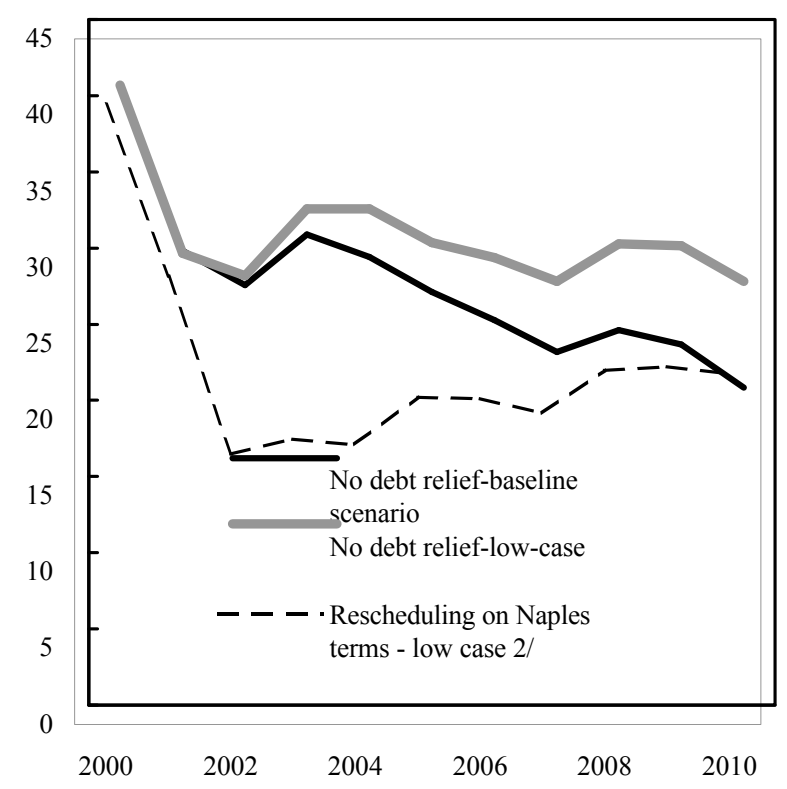

Source: Staff projections

1/ Not identical to Box 3, which includes only scenarios under baseline macroeconomic assumptions.

2/ Stock restructuring in December 2004. 
Appendix Figure 4. Moldova: Debt Sustainability, 2000 - 2010

NPV of debt service

(In percent of exports of GNFS)

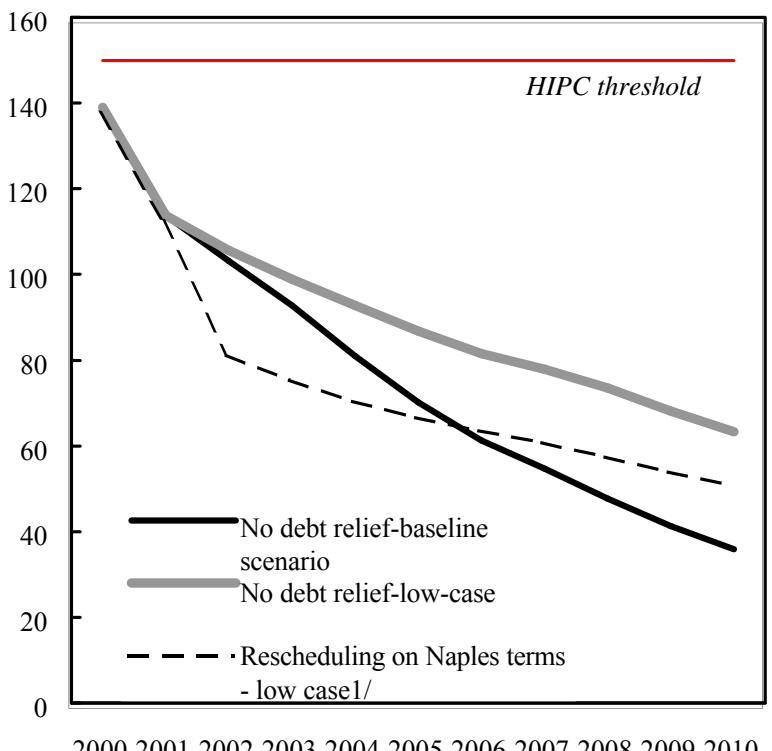

Debt service

(In percent of exports of GNFS)

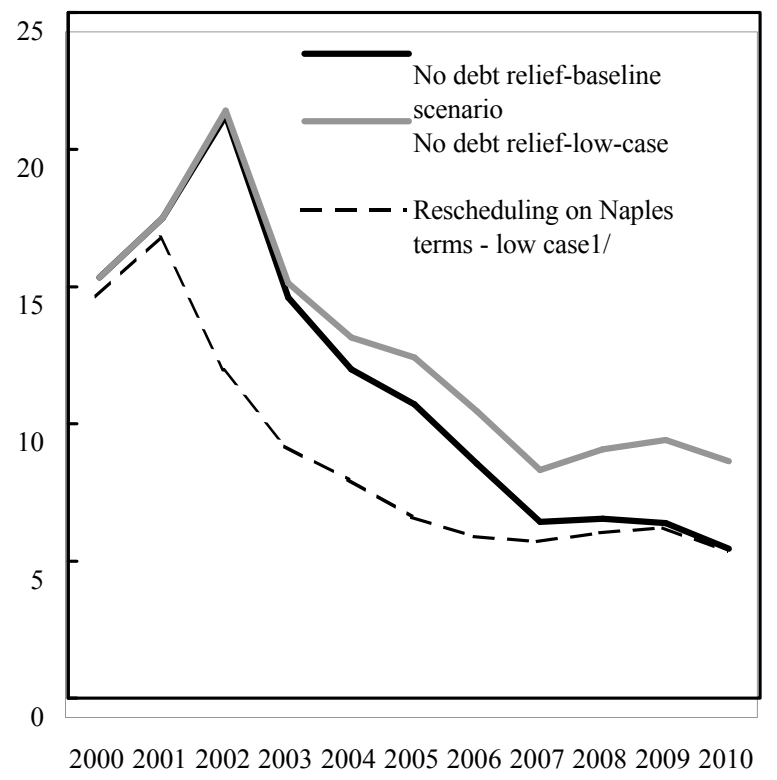

NPV of debt service

(In percent of government revenue)

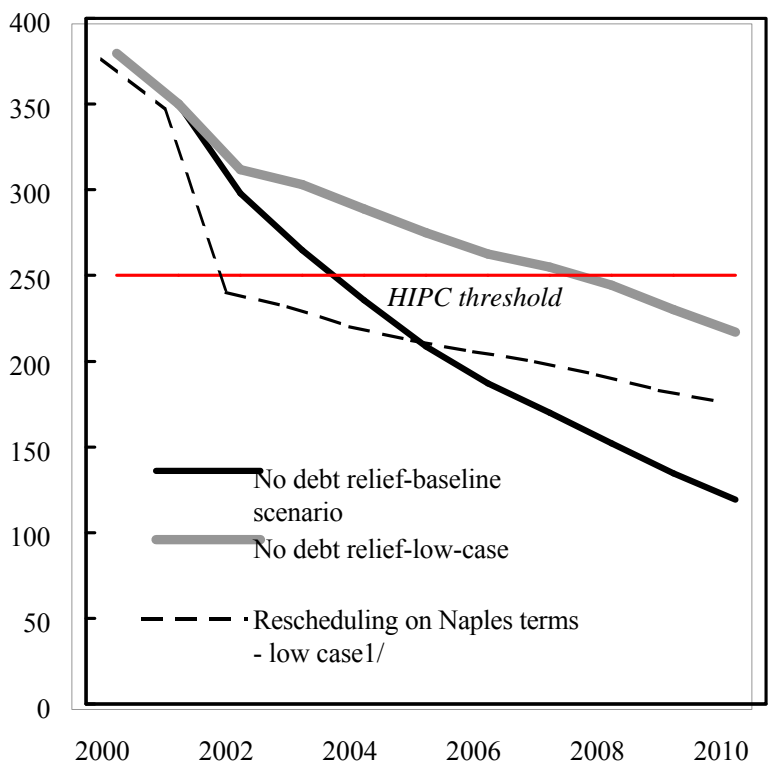

Debt service

(In percent of government revenue)

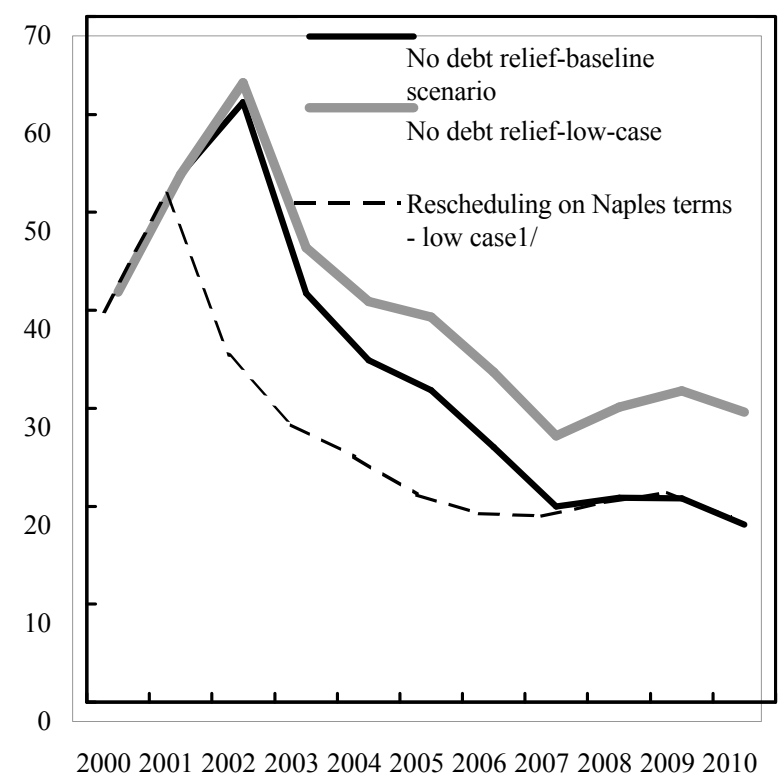

Source: Staff projections

1/ Stock restructuring in Q2 2002. 
Appendix Figure 5. Tajikistan: Debt Sustainability, 2000 - 2010

NPV of debt service

(In percent of exports of GNFS)

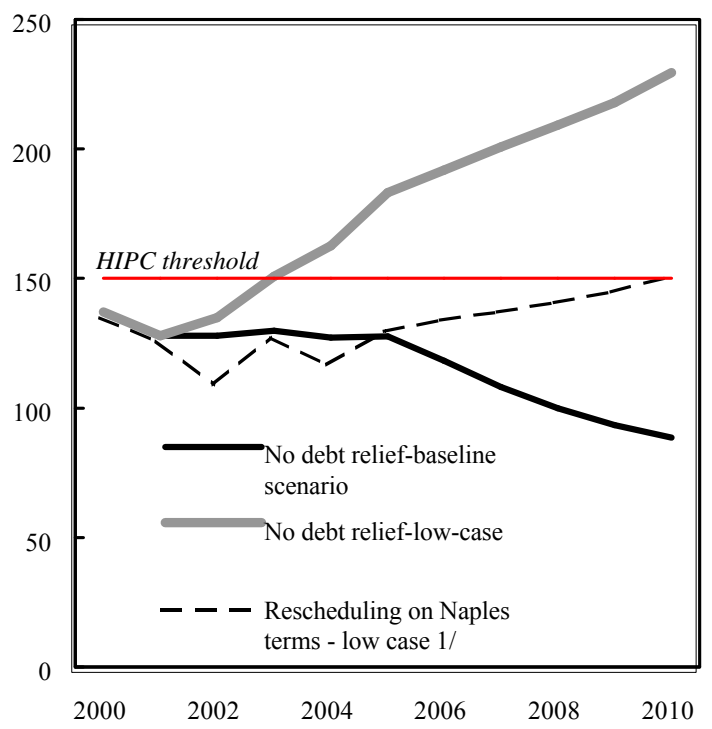

Debt service

(In percent of exports of GNFS)

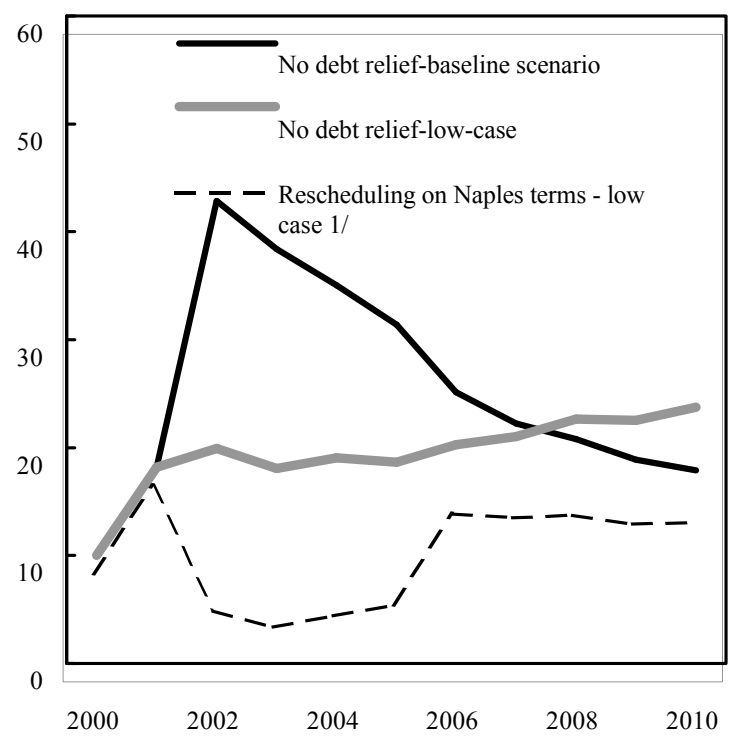

NPV of debt service

(In percent of government revenue)

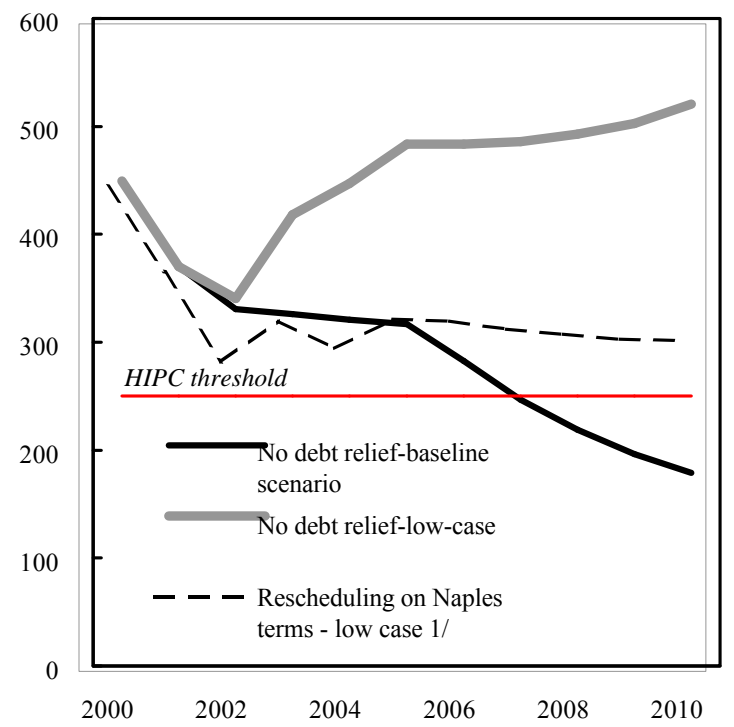

Debt service

(In percent of government revenue)

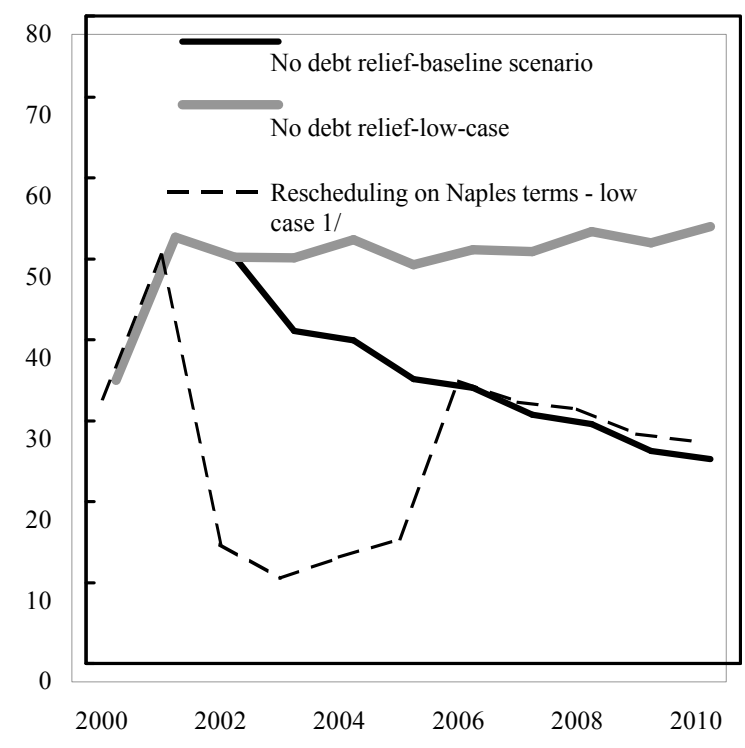

Source: Staff projections

1/ Stock restructuring in 2004. 
Appendix Table 1. Fiscal Indicators

(In percent of GDP)

\begin{tabular}{|c|c|c|c|c|}
\hline & \multirow[t]{2}{*}{ Average for 1995-99 } & \multirow[t]{2}{*}{2000} & \multicolumn{2}{|c|}{ Average for 2001-05 } \\
\hline & & & Baseline & Low-Case \\
\hline \multicolumn{5}{|l|}{ Armenia 1/ } \\
\hline Revenue & 17.4 & 16.5 & 17.2 & 17.2 \\
\hline Expenditure & 23.2 & 22.8 & 20.2 & 20.2 \\
\hline Noninterest & 21.0 & 21.1 & 18.9 & 18.9 \\
\hline Interest & 2.2 & 1.7 & 1.3 & 1.3 \\
\hline Primary balance & -3.6 & -4.7 & -1.7 & -1.7 \\
\hline Total external debt service & 2.9 & 2.5 & 3.2 & 3.3 \\
\hline External current account balance & -17.0 & -14.5 & -9.8 & -10.0 \\
\hline \multicolumn{5}{|l|}{ Georgia 2/ } \\
\hline Revenue & 14.0 & 15.3 & 18.1 & 17.3 \\
\hline Expenditure & 20.9 & 19.4 & 18.2 & 18.0 \\
\hline Noninterest & 18.8 & 16.4 & 16.1 & 15.7 \\
\hline Interest & 2.1 & 3.0 & 2.1 & 2.3 \\
\hline Primary balance & -4.8 & -1.1 & 2.0 & 1.6 \\
\hline Total external debt service & 3.9 & 3.8 & 4.3 & 4.5 \\
\hline External current account balance & -11.1 & -5.4 & -6.2 & -7.4 \\
\hline \multicolumn{5}{|l|}{ Kyrgyz Republic 3/ } \\
\hline Revenue & 16.9 & 15.9 & 18.4 & 18.3 \\
\hline Expenditure & 28.6 & 26.1 & 22.2 & 21.7 \\
\hline Noninterest & 26.9 & 23.2 & 20.1 & 19.7 \\
\hline Interest & 1.7 & 2.9 & 2.0 & 2.0 \\
\hline Primary balance & -10.0 & -7.3 & -1.8 & -1.4 \\
\hline Total external debt service & 5.4 & 9.0 & 8.3 & 9.1 \\
\hline External current account balance & -17.4 & -7.9 & -5.9 & -6.7 \\
\hline \multicolumn{5}{|l|}{ Moldova 2/ } \\
\hline Revenue & 32.0 & 27.6 & 25.9 & 25.5 \\
\hline Expenditure & 39.0 & 29.6 & 27.9 & 28.5 \\
\hline Noninterest & 34.9 & 23.9 & 24.1 & 24.5 \\
\hline Interest & 4.1 & 5.7 & 3.8 & 4.0 \\
\hline Primary balance & -2.9 & 3.7 & 1.8 & 1.1 \\
\hline Total external debt service & 7.8 & 6.9 & 7.2 & 7.7 \\
\hline External current account balance & -10.0 & -8.4 & -7.1 & -6.2 \\
\hline \multicolumn{5}{|l|}{ Tajikistan 2/ } \\
\hline Revenue & 13.0 & 13.6 & 15.1 & 14.2 \\
\hline Expenditure & 17.9 & 14.2 & 15.6 & 15.6 \\
\hline Noninterest & 17.9 & 13.9 & 14.2 & 14.2 \\
\hline Interest & 0.0 & 0.4 & 1.4 & 1.4 \\
\hline Primary balance & -4.9 & -0.3 & 0.8 & 0.0 \\
\hline Total external debt service & 8.4 & 4.6 & 6.5 & 7.6 \\
\hline External current account balance & -8.4 & -6.5 & -5.7 & -8.6 \\
\hline
\end{tabular}

Sources: Ministries of Finance and Central Banks of respective countries; and staff estimates.

1/ Central government; average for 1997-99.

2/ General government.

3/ State government (excludes extrabudgetary funds). 
Appendix Table 2. Foreign Direct Investment (In percent of GDP; period average)

\begin{tabular}{lrr}
\hline & 1995-2000 & $\begin{array}{r}2001-2005 \\
\text { (Forcast) }\end{array}$ \\
\hline Armenia & 5.2 & 5.3 \\
Georgia & 3.8 & 3.7 \\
Kyrgyz Republic & 4.4 & 2.6 \\
Moldova & 3.9 & 7.2 \\
Tajikistan & 1.8 & 1.9 \\
& & \\
\hline
\end{tabular}

Sources: national authorities; and staff estimates. 
Appendix Table 3. CIS7: Directions of Trade, Import Shares, 1995 - 2000

\begin{tabular}{|c|c|c|c|c|c|c|}
\hline & 1995 & 1996 & 1997 & 1998 & 1999 & 2000 \\
\hline CIS7 & 100.0 & 100.0 & 100.0 & 100.0 & 100.0 & 100.0 \\
\hline Intra CIS7 & $\ldots$ & 9.1 & 9.9 & 8.3 & 9.7 & 9.1 \\
\hline Russia & 24.9 & 21.9 & 21.4 & 17.9 & 15.6 & 16.8 \\
\hline Rest of CIS & 16.9 & 14.0 & 12.2 & 11.0 & 10.0 & 12.4 \\
\hline EU & 17.2 & 18.0 & 18.2 & 22.5 & 22.3 & 23.0 \\
\hline Rest of world & $\ldots$ & 37.0 & 38.3 & 40.3 & 42.3 & 38.7 \\
\hline Armenia & 100.0 & 100.0 & 100.0 & 100.0 & 100.0 & 100.0 \\
\hline Intra CIS7 & 8.9 & 6.0 & 4.3 & 3.0 & 3.2 & 2.4 \\
\hline Russia & 19.4 & 14.6 & 24.2 & 21.2 & 21.5 & 15.5 \\
\hline Rest of CIS & 19.7 & 12.4 & 5.0 & 1.3 & 1.2 & 1.7 \\
\hline EU & 15.0 & 15.4 & 19.8 & 28.7 & 30.0 & 34.2 \\
\hline Rest of world & 37.0 & 51.7 & 46.6 & 45.8 & 44.1 & 46.2 \\
\hline Azerbaijan & 100.0 & 100.0 & 100.0 & 100.0 & 100.0 & 100.0 \\
\hline Intra CIS7 & $\ldots$ & 5.0 & 6.5 & 3.0 & 1.3 & 1.4 \\
\hline Russia & 13.2 & 16.5 & 19.1 & 18.0 & 21.9 & 21.3 \\
\hline Rest of CIS & 15.9 & 13.9 & 18.7 & 16.6 & 8.2 & 9.4 \\
\hline EU & 12.7 & 14.2 & 12.5 & 20.8 & 18.4 & 19.4 \\
\hline Rest of world & $\cdots$ & 50.5 & 43.1 & 41.6 & 50.2 & 48.6 \\
\hline Georgia & 100.0 & 100.0 & 100.0 & 100.0 & 100.0 & 100.0 \\
\hline Intra CIS7 & 15.3 & 14.1 & 14.9 & 7.7 & 10.3 & 10.9 \\
\hline Russia & 12.4 & 18.5 & 13.4 & 9.0 & 7.1 & 13.3 \\
\hline Rest of CIS & 12.8 & 6.7 & 8.0 & 4.5 & 10.1 & 8.2 \\
\hline $\mathrm{EU}$ & 16.1 & 24.3 & 22.5 & 26.7 & 21.7 & 23.8 \\
\hline Rest of world & 43.4 & 36.3 & 41.1 & 52.0 & 50.9 & 43.8 \\
\hline Moldova & 100.0 & 100.0 & 100.0 & 100.0 & 100.0 & 100.0 \\
\hline Intra CIS7 & 1.0 & 0.8 & 0.5 & 0.2 & 0.2 & 1.2 \\
\hline Russia & 33.1 & 30.0 & 28.6 & 22.3 & 23.6 & 17.2 \\
\hline Rest of CIS & 33.6 & 30.1 & 22.9 & 19.5 & 15.0 & 17.8 \\
\hline EU & 13.7 & 16.5 & 19.4 & 26.0 & 27.1 & 25.6 \\
\hline Rest of world & 18.6 & 22.6 & 28.6 & 32.0 & 34.1 & 38.2 \\
\hline Kyrgyz Republic & 100.0 & 100.0 & 100.0 & 100.0 & 100.0 & 100.0 \\
\hline Intra CIS7 & 21.0 & 17.7 & 20.4 & 16.2 & 9.5 & 14.2 \\
\hline Russia & 26.8 & 21.9 & 26.9 & 24.3 & 17.9 & 23.9 \\
\hline Rest of CIS & 21.0 & 21.6 & 14.1 & 11.9 & 15.1 & 15.7 \\
\hline EU & 1.6 & 11.5 & 13.1 & 15.6 & 17.9 & 12.0 \\
\hline Rest of world & 29.6 & 27.2 & 25.5 & 32.0 & 39.6 & 34.1 \\
\hline Tajikistan & 100.0 & 100.0 & 100.0 & 100.0 & 100.0 & 100.0 \\
\hline Intra CIS7 & 31.5 & 31.0 & 36.2 & 33.3 & 43.4 & 38.0 \\
\hline Russia & 16.8 & 11.1 & 15.3 & 14.4 & 13.9 & 15.6 \\
\hline Rest of CIS & 10.7 & 15.1 & 12.7 & 15.1 & 20.3 & 16.9 \\
\hline EU & 25.9 & 16.1 & 3.9 & 3.7 & 12.5 & 16.8 \\
\hline Rest of world & 15.0 & 26.6 & 31.9 & 33.5 & 9.9 & 12.8 \\
\hline Uzbekistan & 100.0 & 100.0 & 100.0 & 100.0 & 100.0 & 100.0 \\
\hline Intra CIS7 & 8.3 & 7.2 & 7.0 & 6.7 & 10.6 & 10.2 \\
\hline Russia & 29.9 & 24.5 & 21.2 & 18.1 & 10.5 & 14.3 \\
\hline Rest of CIS & 13.5 & 10.4 & 10.2 & 10.6 & 7.5 & 14.1 \\
\hline EU & 19.4 & 19.9 & 20.9 & 24.6 & 23.1 & 23.3 \\
\hline Rest of world & 28.9 & 38.0 & 40.8 & 39.9 & 48.2 & 38.2 \\
\hline
\end{tabular}

Source: IMF, Directions of Trade Statistics (2001). 
Appendix Table 4. Caucasus: Directions of Trade, Import Shares, 1995 - 2000

\begin{tabular}{|c|c|c|c|c|c|c|}
\hline & 1995 & 1996 & 1997 & 1998 & 1999 & 2000 \\
\hline Caucasus & 100.0 & 100.0 & 100.0 & 100.0 & 100.0 & 100.0 \\
\hline Intra-Caucasus & $\ldots$ & 7.0 & 8.1 & 4.6 & 4.6 & 3.6 \\
\hline Russia & 15.5 & 16.4 & 18.8 & 15.4 & 17.0 & 17.4 \\
\hline Rest of CIS & 17.6 & 12.2 & 10.9 & 7.9 & 6.9 & 7.2 \\
\hline Turkey and Iran & 22.6 & 20.6 & 18.1 & 17.5 & 15.6 & 15.3 \\
\hline Rest of world & $\ldots$ & 43.7 & 44.1 & 54.7 & 55.9 & 56.5 \\
\hline Armenia & 100.0 & 100.0 & 100.0 & 100.0 & 100.0 & 100.0 \\
\hline Intra-Caucasus & 8.9 & 5.9 & 4.3 & 3.0 & 3.2 & 2.2 \\
\hline Russia & 19.4 & 14.6 & 24.2 & 21.2 & 21.5 & 15.5 \\
\hline Rest of CIS & 19.7 & 12.4 & 5.0 & 1.3 & 1.2 & 1.9 \\
\hline Turkey and Iran & 13.3 & 18.1 & 14.3 & 13.4 & 14.1 & 13.9 \\
\hline Rest of world & 38.7 & 49.0 & 52.2 & 61.1 & 60.0 & 66.5 \\
\hline Azerbaijan & 100.0 & 100.0 & 100.0 & 100.0 & 100.0 & 100.0 \\
\hline Intra-Caucasus & $\ldots$ & 2.9 & 4.6 & 2.3 & 0.9 & 0.9 \\
\hline Russia & 13.2 & 16.5 & 19.1 & 18.0 & 21.9 & 21.3 \\
\hline Rest of CIS & 18.0 & 15.9 & 20.6 & 17.2 & 8.6 & 9.9 \\
\hline Turkey and Iran & 33.1 & 29.4 & 28.9 & 24.4 & 18.4 & 15.8 \\
\hline Rest of world & $\cdots$ & 35.2 & 26.8 & 38.0 & 50.2 & 52.1 \\
\hline Georgia & 100.0 & 100.0 & 100.0 & 100.0 & 100.0 & 100.0 \\
\hline Intra-Caucasus & 15.1 & 14.0 & 14.8 & 7.6 & 10.1 & 9.8 \\
\hline Russia & 12.4 & 18.5 & 13.4 & 9.0 & 7.1 & 13.3 \\
\hline Rest of CIS & 13.0 & 6.9 & 8.2 & 4.6 & 10.3 & 9.2 \\
\hline Turkey and Iran & 21.3 & 11.6 & 12.6 & 14.4 & 14.0 & 16.3 \\
\hline Rest of world & 38.2 & 49.1 & 51.0 & 64.3 & 58.6 & 51.3 \\
\hline
\end{tabular}

Source: IMF, Directions of Trade Statistics (2001). 
Appendix Table 5. Central Asia: Directions of Trade, Import Shares, 1995 - 2000

\begin{tabular}{|c|c|c|c|c|c|c|}
\hline & 1995 & 1996 & 1997 & 1998 & 1999 & 2000 \\
\hline Central Asia & 100.0 & 100.0 & 100.0 & 100.0 & 100.0 & 100.0 \\
\hline Intra-Central Asia & 21.7 & 18.0 & 17.2 & 18.9 & 22.0 & 24.6 \\
\hline Russia & 27.1 & 22.7 & 21.1 & 18.7 & 12.3 & 16.2 \\
\hline Rest of CIS & 5.8 & 5.4 & 6.0 & 5.4 & 5.2 & 6.7 \\
\hline Iran, Pakistan and Afganistan & 4.6 & 3.4 & 3.0 & 0.9 & 0.8 & 0.9 \\
\hline Rest of world & 40.7 & 50.6 & 52.6 & 56.1 & 59.7 & 51.6 \\
\hline Kyrgyz Republic & 100.0 & 100.0 & 100.0 & 100.0 & 100.0 & 100.0 \\
\hline Intra-Central Asia & 37.6 & 36.6 & 31.5 & 25.2 & 22.1 & 27.6 \\
\hline Russia & 26.8 & 21.9 & 26.9 & 24.3 & 17.9 & 23.9 \\
\hline Rest of CIS & 4.4 & 2.7 & 3.0 & 2.9 & 2.5 & 2.4 \\
\hline Iran, Pakistan and Afganistan & 18.9 & 0.9 & 1.5 & 1.1 & 1.4 & 1.7 \\
\hline Rest of world & 12.4 & 37.8 & 37.1 & 46.5 & 56.0 & 44.5 \\
\hline Tajikistan & 100.0 & 100.0 & 100.0 & 100.0 & 100.0 & 100.0 \\
\hline Intra-Central Asia & 41.7 & 42.6 & 45.1 & 44.4 & 55.1 & 45.2 \\
\hline Russia & 16.8 & 11.1 & 15.3 & 14.4 & 13.9 & 15.6 \\
\hline Rest of CIS & 0.5 & 3.5 & 3.8 & 4.0 & 8.6 & 9.7 \\
\hline Iran, Pakistan and Afganistan & 0.6 & 2.8 & 1.8 & 1.7 & 1.6 & 1.2 \\
\hline Rest of world & 40.4 & 39.9 & 33.9 & 35.6 & 20.8 & 28.4 \\
\hline Uzbekistan & 100.0 & 100.0 & 100.0 & 100.0 & 100.0 & 100.0 \\
\hline Intra-Central Asia & 14.4 & 11.6 & 10.4 & 10.9 & 13.2 & 17.3 \\
\hline Russia & 29.9 & 24.5 & 21.2 & 18.1 & 10.5 & 14.3 \\
\hline Rest of CIS & 7.5 & 6.1 & 6.8 & 6.4 & 5.0 & 6.9 \\
\hline Iran, Pakistan and Afganistan & 3.8 & 3.8 & 3.5 & 0.7 & 0.5 & 0.5 \\
\hline Rest of world & 44.5 & 54.1 & 58.1 & 63.9 & 70.9 & 60.9 \\
\hline
\end{tabular}

Source: IMF, Directions of Trade Statistics (2001). 
Appendix Table 6. CIS7: Directions of Trade, Export Shares, 1995 - 2000

\begin{tabular}{|c|c|c|c|c|c|c|}
\hline & 1995 & 1996 & 1997 & 1998 & 1999 & 2000 \\
\hline CIS7 & 100.0 & 100.0 & 100.0 & 100.0 & 100.0 & 100.0 \\
\hline Intra CIS7 & $\ldots$ & 14.3 & 13.7 & 12.6 & 12.9 & 9.4 \\
\hline Russia & 28.1 & 25.8 & 29.7 & 22.0 & 19.1 & 21.7 \\
\hline Rest of CIS & 14.0 & 9.7 & 9.2 & 9.2 & 8.5 & 7.7 \\
\hline EU & 21.8 & 19.1 & 17.5 & 25.3 & 30.0 & 33.4 \\
\hline Rest of world & $\ldots$ & 31.1 & 29.9 & 30.9 & 29.6 & 27.8 \\
\hline Armenia & 100.0 & 100.0 & 100.0 & 100.0 & 100.0 & 100.0 \\
\hline Intra CIS7 & 0.9 & 2.5 & 4.8 & 4.6 & 5.0 & 5.4 \\
\hline Russia & 25.4 & 33.1 & 27.0 & 18.1 & 14.6 & 14.8 \\
\hline Rest of CIS & 21.2 & 8.5 & 8.3 & 12.6 & 4.2 & 3.7 \\
\hline EU & 22.2 & 21.3 & 28.5 & 34.6 & 46.0 & 35.6 \\
\hline Rest of world & 30.3 & 34.6 & 31.4 & 30.1 & 30.2 & 40.5 \\
\hline Azerbaijan & 100.0 & 100.0 & 100.0 & 100.0 & 100.0 & 100.0 \\
\hline Intra CIS7 & $\ldots$ & 16.4 & 18.5 & 14.1 & 9.4 & 5.6 \\
\hline Russia & 18.1 & 17.6 & 23.1 & 17.4 & 8.9 & 5.6 \\
\hline Rest of CIS & 11.7 & 11.9 & 6.8 & 6.7 & 4.4 & 2.3 \\
\hline EU & 17.1 & 9.3 & 11.2 & 21.7 & 45.6 & 60.4 \\
\hline Rest of world & $\cdots$ & 44.7 & 40.4 & 40.1 & 31.7 & 26.1 \\
\hline Georgia & 100.0 & 100.0 & 100.0 & 100.0 & 100.0 & 100.0 \\
\hline Intra CIS7 & 21.1 & 24.7 & 21.7 & 16.2 & 11.7 & 10.8 \\
\hline Russia & 31.0 & 28.5 & 29.8 & 17.0 & 12.6 & 20.6 \\
\hline Rest of CIS & 10.4 & 11.4 & 8.2 & 7.1 & 10.8 & 9.8 \\
\hline $\mathrm{EU}$ & 4.8 & 8.5 & 8.8 & 19.7 & 29.5 & 20.7 \\
\hline Rest of world & 32.7 & 26.9 & 31.5 & 40.0 & 35.5 & 38.0 \\
\hline Moldova & 100.0 & 100.0 & 100.0 & 100.0 & 100.0 & 100.0 \\
\hline Intra CIS7 & 1.5 & 3.0 & 1.4 & 1.1 & 1.1 & 1.0 \\
\hline Russia & 48.3 & 54.0 & 58.1 & 53.7 & 35.9 & 36.7 \\
\hline Rest of CIS & 12.8 & 11.4 & 9.9 & 13.2 & 9.4 & 11.2 \\
\hline $\mathrm{EU}$ & 11.6 & 9.8 & 10.3 & 12.5 & 20.5 & 20.3 \\
\hline Rest of world & 25.8 & 21.8 & 20.2 & 19.5 & 33.0 & 30.8 \\
\hline Kyrgyz Republic & 100.0 & 100.0 & 100.0 & 100.0 & 100.0 & 100.0 \\
\hline Intra CIS7 & 20.3 & 26.0 & 19.3 & 9.3 & 12.9 & 20.3 \\
\hline Russia & 23.7 & 26.5 & 16.2 & 16.3 & 15.6 & 13.0 \\
\hline Rest of CIS & 29.2 & 25.7 & 16.9 & 19.3 & 11.9 & 8.0 \\
\hline $\mathrm{EU}$ & 11.9 & 3.9 & 4.9 & 41.4 & 38.2 & 34.1 \\
\hline Rest of world & 15.0 & 17.9 & 42.7 & 13.7 & 21.4 & 24.6 \\
\hline Tajikistan & 100.0 & 100.0 & 100.0 & 100.0 & 100.0 & 100.0 \\
\hline Intra CIS7 & 18.1 & 26.5 & 22.7 & 22.1 & 26.9 & 14.7 \\
\hline Russia & 12.7 & 10.2 & 7.9 & 8.0 & 16.7 & 33.0 \\
\hline Rest of CIS & 2.8 & 6.2 & 3.4 & 3.9 & 2.2 & 1.8 \\
\hline $\mathrm{EU}$ & 46.3 & 34.5 & 33.5 & 43.3 & 36.1 & 28.1 \\
\hline Rest of world & 20.1 & 22.6 & 32.5 & 22.7 & 18.2 & 22.4 \\
\hline Uzbekistan & 100.0 & 100.0 & 100.0 & 100.0 & 100.0 & 100.0 \\
\hline Intra CIS7 & 11.1 & 11.9 & 12.5 & 13.9 & 14.8 & 11.5 \\
\hline Russia & 29.7 & 22.6 & 31.9 & 20.5 & 21.7 & 28.3 \\
\hline Rest of CIS & 14.5 & 6.7 & 9.8 & 7.9 & 11.6 & 13.3 \\
\hline $\mathrm{EU}$ & 21.5 & 23.3 & 19.4 & 21.4 & 19.9 & 19.7 \\
\hline Rest of world & 23.2 & 35.6 & 26.4 & 36.3 & 32.1 & 27.3 \\
\hline
\end{tabular}

Source: IMF, Directions of Trade Statistics (2001). 
Appendix Table 7. Caucasus: Directions of Trade, Export Shares, 1995 - 2000

\begin{tabular}{|c|c|c|c|c|c|c|}
\hline & 1995 & 1996 & 1997 & 1998 & 1999 & 2000 \\
\hline Caucasus & 100.0 & 100.0 & 100.0 & 100.0 & 100.0 & 100.0 \\
\hline Intra-Caucasus &.. & 12.8 & 15.1 & 11.5 & 7.6 & 5.3 \\
\hline Russia & 22.4 & 23.6 & 25.1 & 17.4 & 10.7 & 8.9 \\
\hline Rest of CIS & 16.0 & 12.4 & 8.7 & 9.4 & 7.5 & 4.5 \\
\hline Turkey and Iran & 24.9 & 30.6 & 25.3 & 25.5 & 13.9 & 9.5 \\
\hline Rest of world & $\ldots$ & 20.6 & 25.8 & 36.2 & 60.3 & 71.9 \\
\hline Armenia & 100.0 & 100.0 & 100.0 & 100.0 & 100.0 & 100.0 \\
\hline Intra-Caucasus & 0.8 & 2.4 & 4.6 & 4.3 & 4.8 & 5.3 \\
\hline Russia & 25.4 & 33.1 & 27.0 & 18.1 & 14.6 & 14.8 \\
\hline Rest of CIS & 21.3 & 8.6 & 8.4 & 12.9 & 4.4 & 3.8 \\
\hline Turkey and Iran & 10.5 & 17.2 & 21.4 & 15.6 & 15.2 & 10.5 \\
\hline Rest of world & 41.9 & 38.7 & 38.6 & 49.1 & 60.9 & 65.6 \\
\hline Azerbaijan & 100.0 & 100.0 & 100.0 & 100.0 & 100.0 & 100.0 \\
\hline Intra-Caucasus & $\ldots$ & 14.5 & 17.1 & 12.7 & 7.7 & 4.3 \\
\hline Russia & 18.1 & 17.6 & 23.1 & 17.4 & 8.9 & 5.6 \\
\hline Rest of CIS & 13.7 & 13.8 & 8.2 & 8.1 & 6.1 & 3.6 \\
\hline Turkey and Iran & 34.7 & 42.0 & 29.6 & 29.7 & 9.9 & 6.5 \\
\hline Rest of world & $\ldots$ & 12.0 & 22.0 & 32.1 & 67.4 & 80.1 \\
\hline Georgia & 100.0 & 100.0 & 100.0 & 100.0 & 100.0 & 100.0 \\
\hline Intra-Caucasus & 20.1 & 22.8 & 19.1 & 14.0 & 9.2 & 10.5 \\
\hline Russia & 31.0 & 28.5 & 29.8 & 17.0 & 12.6 & 20.6 \\
\hline Rest of CIS & 11.4 & 13.3 & 10.8 & 9.4 & 13.3 & 10.2 \\
\hline Turkey and Iran & 23.1 & 14.1 & 14.7 & 24.4 & 23.5 & 24.3 \\
\hline Rest of world & 14.4 & 21.2 & 25.6 & 35.2 & 41.4 & 34.4 \\
\hline
\end{tabular}

Source: IMF, Directions of Trade Statistics (2001). 
Appendix Table 8. Central Asia: Directions of Trade, Export Shares, 1995 - 2000

\begin{tabular}{|c|c|c|c|c|c|c|}
\hline & 1995 & 1996 & 1997 & 1998 & 1999 & 2000 \\
\hline Central Asia & 100.0 & 100.0 & 100.0 & 100.0 & 100.0 & 100.0 \\
\hline Intra-Central Asia & 23.6 & 22.1 & 20.9 & 21.2 & 22.7 & 17.0 \\
\hline Russia & 25.8 & 20.7 & 25.2 & 17.7 & 19.7 & 27.1 \\
\hline Rest of CIS & 4.0 & 3.5 & 4.1 & 2.4 & 4.0 & 6.4 \\
\hline Iran, Pakistan and Afganistan & 0.3 & 1.0 & 0.8 & 1.3 & 2.9 & 0.9 \\
\hline Rest of world & 46.3 & 52.7 & 49.1 & 57.5 & 50.8 & 48.6 \\
\hline Kyrgyz Republic & 100.0 & 100.0 & 100.0 & 100.0 & 100.0 & 100.0 \\
\hline Intra-Central Asia & 46.5 & 47.9 & 33.4 & 26.0 & 22.8 & 26.5 \\
\hline Russia & 23.7 & 26.5 & 16.2 & 16.3 & 15.6 & 13.0 \\
\hline Rest of CIS & 3.0 & 3.8 & 2.7 & 2.6 & 2.0 & 1.8 \\
\hline Iran, Pakistan and Afganistan & 0.7 & 2.6 & 1.9 & 1.7 & 2.3 & 2.2 \\
\hline Rest of world & 26.1 & 19.2 & 45.7 & 53.4 & 57.3 & 56.5 \\
\hline Tajikistan & 100.0 & 100.0 & 100.0 & 100.0 & 100.0 & 100.0 \\
\hline Intra-Central Asia & 19.2 & 30.3 & 25.1 & 25.2 & 27.6 & 14.1 \\
\hline Russia & 12.7 & 10.2 & 7.9 & 8.0 & 16.7 & 33.0 \\
\hline Rest of CIS & 1.7 & 2.3 & 1.0 & 0.8 & 1.5 & 2.3 \\
\hline Iran, Pakistan and Afganistan & 0.1 & 0.6 & 0.5 & 2.4 & 2.3 & 1.9 \\
\hline Rest of world & 66.3 & 56.5 & 65.5 & 63.6 & 52.0 & 48.6 \\
\hline Uzbekistan & 100.0 & 100.0 & 100.0 & 100.0 & 100.0 & 100.0 \\
\hline Intra-Central Asia & 20.7 & 14.8 & 17.1 & 19.1 & 21.0 & 15.8 \\
\hline Russia & 29.7 & 22.6 & 31.9 & 20.5 & 21.7 & 28.3 \\
\hline Rest of CIS & 4.9 & 3.8 & 5.2 & 2.7 & 5.3 & 9.0 \\
\hline Iran, Pakistan and Afganistan & 0.2 & 0.9 & 0.6 & 0.9 & 3.2 & 0.3 \\
\hline Rest of world & 44.4 & 58.0 & 45.3 & 56.8 & 48.8 & 46.7 \\
\hline
\end{tabular}

Source: IMF, Directions of Trade Statistics (2001). 
Appendix Table 9a. Armenia: Debt Sustainability Analysis--Baseline Scenario

(In percent)

\begin{tabular}{|c|c|c|c|c|c|c|c|c|c|c|c|}
\hline & 2000 & 2001 & 2002 & 2003 & 2004 & 2005 & 2006 & 2007 & 2008 & 2009 & 2010 \\
\hline \multicolumn{12}{|l|}{ No debt relief } \\
\hline \multicolumn{12}{|l|}{ Ratio of NPV of external debt to: } \\
\hline Exports of goods and services & 135 & 124 & 117 & 109 & 108 & 106 & 107 & 107 & 109 & 111 & 113 \\
\hline Central government revenue & 177 & 168 & 167 & 153 & 146 & 139 & 140 & 141 & 144 & 147 & 150 \\
\hline \multicolumn{12}{|l|}{ Ratio of debt service to: } \\
\hline Exports of goods and services & 11 & 12 & 15 & 16 & 11 & 10 & 9 & 9 & 7 & 7 & 6 \\
\hline Central government revenue & 16 & 19 & 24 & 24 & 16 & 14 & 13 & 13 & 10 & 10 & 9 \\
\hline \multicolumn{12}{|l|}{ Assumptions } \\
\hline Real GDP growth & 6.0 & 7.5 & 6.0 & 6.0 & 5.0 & 5.0 & 5.0 & 5.0 & 5.0 & 5.0 & 5.0 \\
\hline \multicolumn{12}{|l|}{ Growth in external trade: } \\
\hline Exports of goods and services & 16.6 & 16.8 & 7.5 & 9.8 & 8.4 & 8.4 & 8.4 & 8.4 & 8.4 & 8.4 & 8.4 \\
\hline Imports of goods and services & 5.1 & 0.6 & 4.0 & 6.9 & 6.1 & 6.1 & 6.1 & 6.1 & 6.2 & 6.2 & 6.2 \\
\hline RER change (against US dollar) $1 /$ & -3.5 & 2.8 & 0.0 & 0.0 & 0.0 & 0.0 & 0.0 & 0.0 & 0.0 & 0.0 & 0.0 \\
\hline FDI (in percent of GDP) & 5.4 & 6.8 & 3.6 & 4.9 & 5.7 & 5.6 & 5.5 & 5.1 & 4.7 & 4.4 & 4.0 \\
\hline Central government revenue (in percent of GDP) & 15.8 & 16.0 & 16.1 & 16.7 & 17.3 & 18.0 & 18.0 & 18.0 & 18.0 & 18.0 & 18.0 \\
\hline
\end{tabular}

Source: Staff projections.

1/ A positive sign means appreciation.

Appendix Table 9b. Armenia: Debt Sustainability Analysis--Low-Case Scenario (In percent)

\begin{tabular}{|c|c|c|c|c|c|c|c|c|c|c|c|}
\hline & & 2001 & 2002 & 2003 & 2004 & 2005 & 2006 & 2007 & 2008 & 2009 & 2010 \\
\hline \multicolumn{12}{|l|}{ No debt relief } \\
\hline \multicolumn{12}{|l|}{ Ratio of NPV of external debt to: } \\
\hline Exports of goods and services & 135 & 124 & 117 & 114 & 116 & 122 & 129 & 136 & 146 & 155 & 164 \\
\hline Central government revenue & 177 & 168 & 167 & 161 & 160 & 161 & 171 & 180 & 192 & 205 & 217 \\
\hline \multicolumn{12}{|l|}{ Ratio of debt service to: } \\
\hline Exports of goods and services & 11 & 12 & 15 & 16 & 11 & 11 & 11 & 11 & 9 & 9 & 9 \\
\hline Central government revenue & 16 & 19 & 24 & 24 & 16 & 16 & 15 & 15 & 12 & 13 & 12 \\
\hline \multicolumn{12}{|l|}{ Rescheduling on Naples terms (flow restructuring) } \\
\hline \multicolumn{12}{|l|}{ Ratio of NPV of external debt to: } \\
\hline Exports of goods and services & $\ldots$ & $\ldots$ & $\ldots$ & $\ldots$ & $\ldots$ & $\ldots$ & & $\ldots$ & $\ldots$ & 153 & 161 \\
\hline Central government revenue & $\cdots$ & $\cdots$ & $\ldots$ & $\ldots$ & $\ldots$ & $\ldots$ & $\ldots$ & $\cdots$ & $\cdots$ & 203 & 214 \\
\hline \multicolumn{12}{|l|}{ Ratio of debt service to: } \\
\hline Exports of goods and services & $\ldots$ & $\ldots$ & $\ldots$ & $\ldots$ & $\ldots$ & $\ldots$ & $\ldots$ & $\ldots$ & $\ldots$ & 9 & 7 \\
\hline Central government revenue & $\ldots$ & $\cdots$ & $\cdots$ & $\cdots$ & $\cdots$ & $\cdots$ & $\cdots$ & $\cdots$ & $\cdots$ & 13 & 10 \\
\hline \multicolumn{12}{|l|}{ Assumptions } \\
\hline Real GDP growth & 6.0 & 7.5 & 6.0 & 4.0 & 3.0 & 3.0 & 3.0 & 3.0 & 3.0 & 3.0 & 3.0 \\
\hline \multicolumn{12}{|l|}{ Growth in external trade: } \\
\hline Exports of goods and services & 16.6 & 16.8 & 7.5 & 7.6 & 6.0 & 6.0 & 6.0 & 6.0 & 6.0 & 6.0 & 6.0 \\
\hline Imports of goods and services & 5.1 & 0.6 & 4.0 & 6.1 & 4.5 & 4.5 & 4.5 & 4.6 & 4.6 & 4.6 & 4.6 \\
\hline RER change (against US dollar) 1/ & -3.5 & 2.8 & 0.0 & 0.0 & 0.0 & 0.0 & 0.0 & 0.0 & 0.0 & 0.0 & 0.0 \\
\hline FDI (in percent of GDP) & 5.4 & 6.8 & 3.6 & 3.9 & 4.7 & 4.6 & 4.5 & 4.1 & 3.7 & 3.4 & 3.0 \\
\hline Central government revenue (in percent of GDP) & 15.8 & 16.0 & 16.1 & 16.7 & 17.3 & 18.0 & 18.0 & 18.0 & 18.0 & 18.0 & 18.0 \\
\hline
\end{tabular}

Source: Staff projections.

1/ A positive sign means appreciation. 
Appendix Table 10a: Armenia: Medium Term Projections, 2000-2005, Baseline Scenario

\begin{tabular}{|c|c|c|c|c|c|c|}
\hline & $\begin{array}{c}2000 \\
\text { Prelim. }\end{array}$ & 2001 & 2002 & 2003 & 2004 & 2005 \\
\hline \multicolumn{7}{|l|}{ Income and prices } \\
\hline Nominal GDP (billions of drams) & 1,033 & 1,149 & 1,254 & 1,369 & 1,481 & 1,601 \\
\hline Nominal GDP (millions of USD) & 1,915 & 2,074 & 2,227 & 2432 & 2630 & 2844 \\
\hline GDP per capita (USD) & 504 & 546 & 586 & 640 & 692 & 748 \\
\hline Real GDP growth (in percent) & 6.0 & 7.5 & 6.0 & 6.0 & 5.0 & 5.0 \\
\hline Consumer prices (in percent, average) & -0.8 & 3.4 & 3.0 & 3.0 & 3.0 & 3.0 \\
\hline RER change (against USD; percent) & -3.5 & 2.8 & 0.0 & 0.0 & 0.0 & 0.0 \\
\hline \multicolumn{7}{|l|}{ Savings and investment balances (all as share in GDP) } \\
\hline Total investment & 18.9 & 21.8 & 21.7 & 21.5 & 21.9 & 21.7 \\
\hline Public & 3.8 & 3.3 & 4.0 & 4.5 & 3.3 & 3.3 \\
\hline On-budget investment & 3.8 & 3.3 & 4.0 & 4.5 & 3.3 & 3.3 \\
\hline \multicolumn{7}{|l|}{ Other public investment } \\
\hline Private $1 /$ & 15.1 & 18.5 & 17.7 & 17.0 & 18.6 & 18.4 \\
\hline Total domestic savings & 4.4 & 10.7 & 11.8 & 12.0 & 12.7 & 12.7 \\
\hline Public & -2.6 & -0.7 & 1.3 & 2.6 & 0.9 & 0.9 \\
\hline Private & 7.0 & 11.4 & 10.5 & 9.3 & 11.8 & 11.8 \\
\hline Foreign savings & -14.5 & -11.1 & -9.9 & -9.5 & -9.2 & -9.0 \\
\hline \multicolumn{7}{|l|}{ Central government (all as share in GDP) 2/ } \\
\hline Total revenue and grants & 16.5 & 17.3 & 17.2 & 17.4 & 17.0 & 17.1 \\
\hline $\mathrm{o} / \mathrm{w}$ Grants & 0.6 & 1.3 & 1.0 & 0.7 & 0.1 & 0.0 \\
\hline Total expenditure & 22.8 & 21.4 & 21.3 & 19.3 & 19.4 & 19.5 \\
\hline Non-interest expenditure & 15.8 & 15.0 & 15.2 & 14.0 & 14.4 & 14.6 \\
\hline Interest & 1.7 & 1.5 & 1.3 & 1.2 & 1.2 & 1.2 \\
\hline Capital expenditure plus net lending & 5.4 & 4.9 & 4.8 & 4.1 & 3.8 & 3.8 \\
\hline \multicolumn{7}{|l|}{ Budget balance } \\
\hline Overall budget balance & -6.4 & -4.0 & -4.3 & -1.9 & -2.5 & -2.5 \\
\hline Primary balance & -4.7 & -2.5 & -3.0 & -0.7 & -1.3 & -1.3 \\
\hline Primary balance excluding investment & -0.8 & 0.8 & 1.0 & 3.8 & 2.1 & 2.1 \\
\hline \multicolumn{7}{|l|}{ External sector } \\
\hline Exports of GNFS (millions of USD) & 447 & 522 & 561 & 616 & 668 & 724 \\
\hline Imports of GNFS (millions of USD) & -966 & -972 & -1011 & -1081 & -1147 & -1217 \\
\hline Gross reserves, excluding pledged (millions of USD) & 314 & 323 & 344 & 347 & 359 & 377 \\
\hline International reserves (months of imports of GNFS) & 3.9 & 3.8 & 3.8 & 3.6 & 3.5 & 3.5 \\
\hline \multicolumn{7}{|l|}{ Debt ratios (in percent) } \\
\hline NPV of public debt-to-exports ratio & 135 & 123 & 116 & 107 & 105 & 103 \\
\hline NPV of public debt-to-revenue ratio & 177 & 169 & 167 & 153 & 148 & 145 \\
\hline Total public debt service to exports ratio & 10.5 & 10.5 & 16.0 & 15.3 & 10.3 & 9.9 \\
\hline Total public debt service to revenue ratio & 15.5 & 16.8 & 25.6 & 23.9 & 15.9 & 15.0 \\
\hline
\end{tabular}

Sources: Armenian Authorities and staff estimates.

1/ According to state budget estimates and projections.

2/ Includes investments by state owned enterprises (SOEs). 
Appendix Table 10b: Armenia: Medium Term Projections, 2000-2005, Low Case Scenario

\begin{tabular}{|c|c|c|c|c|c|c|}
\hline & $\begin{array}{c}2000 \\
\text { Prelim. }\end{array}$ & 2001 & 2002 & 2003 & 2004 & 2005 \\
\hline \multicolumn{7}{|l|}{ Income and prices } \\
\hline Nominal GDP (billions of drams) & 1,033 & 1,149 & 1,254 & 1,343 & 1,425 & 1,512 \\
\hline Nominal GDP (millions of USD) & 1,915 & 2,073 & 2,227 & 2,386 & 2,531 & 2,685 \\
\hline GDP per capita (USD) & 504 & 546 & 586 & 628 & 666 & 707 \\
\hline Real GDP growth (in percent) & 6.0 & 7.5 & 6.0 & 4.0 & 3.0 & 3.0 \\
\hline Consumer prices (in percent, average) & -0.8 & 3.4 & 3.0 & 3.0 & 3.0 & 3.0 \\
\hline RER change (against USD; percent) & -3.5 & 2.8 & 0.0 & 0.0 & 0.0 & 0.0 \\
\hline \multicolumn{7}{|l|}{ Savings and investment balances (all as share in GDP) } \\
\hline Total investment & 18.9 & 21.8 & 21.7 & 20.5 & 20.9 & 20.7 \\
\hline Public & 3.8 & 3.3 & 4.0 & 4.5 & 3.3 & 3.3 \\
\hline On-budget investment & 3.8 & 3.3 & 4.0 & 4.5 & 3.3 & 3.3 \\
\hline Other public investment & & & & & & \\
\hline Private $1 /$ & 15.1 & 18.5 & 17.7 & 16.0 & 17.6 & 17.4 \\
\hline Total domestic savings & 4.4 & 10.7 & 11.8 & 10.6 & 11.3 & 11.3 \\
\hline Public & -2.6 & -0.7 & 1.3 & 2.6 & 0.9 & 0.9 \\
\hline Private & 7.0 & 11.4 & 10.5 & 7.9 & 10.4 & 10.4 \\
\hline Foreign savings & -14.5 & -11.1 & -9.9 & -9.9 & -9.7 & -9.6 \\
\hline \multicolumn{7}{|l|}{ Central government (all as share in GDP) 2/ } \\
\hline Total revenue and grants & 16.5 & 17.3 & 17.2 & 17.4 & 17.0 & 17.1 \\
\hline o/w Grants & 0.6 & 1.3 & 1.0 & 0.7 & 0.1 & 0.0 \\
\hline Total expenditure & 22.8 & 21.4 & 21.3 & 19.3 & 19.4 & 19.5 \\
\hline Non-interest expenditure & 15.8 & 15.0 & 15.2 & 14.0 & 14.4 & 14.6 \\
\hline Interest & 1.7 & 1.5 & 1.3 & 1.2 & 1.2 & 1.2 \\
\hline Capital expenditure plus net lending & 5.4 & 4.9 & 4.8 & 4.1 & 3.8 & 3.8 \\
\hline \multicolumn{7}{|l|}{ Budget balance } \\
\hline Overall budget balance & -6.4 & -4.0 & -4.3 & -1.9 & -2.5 & -2.5 \\
\hline Primary balance & -4.7 & -2.5 & -3.0 & -0.7 & -1.3 & -1.3 \\
\hline Primary balance excluding investment & -0.8 & 0.8 & 1.0 & 3.8 & 2.1 & 2.1 \\
\hline \multicolumn{7}{|l|}{ External sector } \\
\hline Exports of GNFS (millions of USD) & 447 & 522 & 561 & 604 & 640 & 678 \\
\hline Imports of GNFS (millions of USD) & -966 & -972 & -1011 & -1073 & -1122 & -1172 \\
\hline Gross reserves, excluding pledged (millions of USD) & 314 & 323 & 344 & 347 & 339 & 358 \\
\hline International reserves (months of imports of GNFS) & 3.9 & 3.8 & 3.8 & 3.7 & 3.5 & 3.5 \\
\hline \multicolumn{7}{|l|}{ Debt ratios (in percent) } \\
\hline NPV of public debt-to-exports ratio & 135 & 124 & 117 & 114 & 116 & 122 \\
\hline NPV of public debt-to-revenue ratio & 177 & 168 & 167 & 161 & 160 & 161 \\
\hline Total public debt service to exports ratio & 10.5 & 11.9 & 15.1 & 16.0 & 11.3 & 11.2 \\
\hline Total public debt service to revenue ratio & 15.5 & 18.7 & 23.7 & 24.3 & 16.5 & 15.7 \\
\hline
\end{tabular}

Sources: Armenian Authorities and staff estimates.

1/ According to state budget estimates and projections.

2/ Includes investments by state owned enterprises (SOEs). 
Appendix Table 11a. Georgia: Debt Sustainability Analysis--Baseline Scenario (In percent)

\begin{tabular}{|c|c|c|c|c|c|c|c|c|c|c|c|}
\hline & 2000 & 2001 & 2002 & 2003 & 2004 & 2005 & 2006 & 2007 & 2008 & 2009 & 2010 \\
\hline \multicolumn{12}{|l|}{ No debt relief } \\
\hline \multicolumn{12}{|l|}{ Ratio of NPV of external debt to: } \\
\hline Exports of goods and services & 128 & 110 & 99 & 98 & 93 & 89 & 85 & 78 & 71 & 65 & 59 \\
\hline Central government revenue & 356 & 312 & 301 & 295 & 273 & 252 & 233 & 209 & 190 & 172 & 154 \\
\hline \multicolumn{12}{|l|}{ Ratio of debt service to: } \\
\hline Exports of goods and services & 10 & 8 & 10 & 14 & 14 & 12 & 10 & 9 & 9 & 9 & 9 \\
\hline Central government revenue & 36 & 25 & 31 & 45 & 43 & 36 & 31 & 27 & 25 & 26 & 26 \\
\hline \multicolumn{12}{|l|}{ Rescheduling on Houston terms 1/ } \\
\hline \multicolumn{12}{|l|}{ Ratio of NPV of external debt to: } \\
\hline Exports of goods and services & 128 & 108 & 97 & 100 & 99 & 94 & 90 & 82 & 76 & 69 & 63 \\
\hline Central government revenue & 356 & 306 & 295 & 301 & 289 & 266 & 246 & 221 & 201 & 182 & 164 \\
\hline \multicolumn{12}{|l|}{ Ratio of debt service to: } \\
\hline Exports of goods and services & 10 & 8 & 10 & 10 & 10 & 12 & 11 & 9 & 9 & 9 & 9 \\
\hline Central government revenue & 36 & 25 & 31 & 33 & 33 & 37 & 31 & 28 & 26 & 27 & 27 \\
\hline \multicolumn{12}{|c|}{ Rescheduling on Naples terms (flow restructuring of 2003-04 maturities) } \\
\hline \multicolumn{12}{|l|}{ Ratio of NPV of external debt to: } \\
\hline Exports of goods and services & 128 & 104 & 93 & 96 & 95 & 91 & 86 & 79 & 73 & 67 & 60 \\
\hline Central government revenue & 356 & 294 & 283 & 289 & 278 & 256 & 237 & 212 & 194 & 176 & 157 \\
\hline \multicolumn{12}{|l|}{ Ratio of debt service to: } \\
\hline Exports of goods and services & 10 & 8 & 10 & 10 & 10 & 12 & 10 & 9 & 9 & 9 & 9 \\
\hline Central government revenue & 36 & 25 & 31 & 33 & 32 & 36 & 31 & 27 & 26 & 26 & 26 \\
\hline \multicolumn{12}{|c|}{ Rescheduling on Naples terms (stock-of-debt operation following flow restructuring) } \\
\hline \multicolumn{12}{|l|}{ Ratio of NPV of external debt to: } \\
\hline Exports of goods and services & 128 & 82 & 73 & 75 & 75 & 74 & 73 & 69 & 65 & 61 & 56 \\
\hline Central government revenue & 356 & 232 & 221 & 227 & 218 & 210 & 202 & 186 & 174 & 160 & 146 \\
\hline \multicolumn{12}{|l|}{ Ratio of debt service to: } \\
\hline Exports of goods and services & 10 & 8 & 10 & 10 & 10 & 8 & 7 & 7 & 7 & 8 & 8 \\
\hline Central government revenue & 36 & 25 & 31 & 33 & 32 & 26 & 21 & 19 & 21 & 23 & 22 \\
\hline \multicolumn{12}{|l|}{ Assumptions } \\
\hline Real GDP growth & 1.9 & 3.9 & 3.3 & 4.0 & 4.0 & 4.0 & 4.0 & 4.0 & 3.5 & 3.5 & 3.5 \\
\hline \multicolumn{12}{|l|}{ Growth in external trade: } \\
\hline Exports of goods and services & $\ldots$ & 1.5 & 7.2 & 7.0 & 7.6 & 7.5 & 8.7 & 9.5 & 7.8 & 8.0 & 8.2 \\
\hline Imports of goods and services & $\ldots$ & 5.5 & 4.4 & 6.4 & 10.9 & 6.5 & 4.8 & 4.7 & 4.4 & 5.6 & 6.7 \\
\hline RER change (against US dollar) 2/ & 2.9 & 0.2 & -2.9 & -3.3 & 0.6 & 0.9 & 0.7 & 0.7 & 0.7 & 0.7 & 0.7 \\
\hline FDI (in percent of GDP) & 5.1 & 3.2 & 2.0 & 2.8 & 5.3 & 5.2 & 4.3 & 3.4 & 2.4 & 2.0 & 2.0 \\
\hline Central government revenue (in percent of GDP) & 10.3 & 10.9 & 11.5 & 11.9 & 12.2 & 12.6 & 13.1 & 13.5 & 13.8 & 14.2 & 14.5 \\
\hline
\end{tabular}

Source: Staff projections.

$1 /$ Based on Georgian rescheduling in 2001.

2/ A positive sign means appreciation. 
Appendix Table 11b. Georgia: Debt Sustainability Analysis--Low-Case Scenario (In percent)

\begin{tabular}{|c|c|c|c|c|c|c|c|c|c|c|c|}
\hline & 2000 & 2001 & 2002 & 2003 & 2004 & 2005 & 2006 & 2007 & 2008 & 2009 & 2010 \\
\hline \multicolumn{12}{|l|}{ No debt relief } \\
\hline \multicolumn{12}{|l|}{ Ratio of NPV of external debt to: } \\
\hline Exports of goods and services & 128 & 111 & 100 & 101 & 100 & 101 & 102 & 100 & 101 & 101 & 101 \\
\hline Central government revenue & 356 & 326 & 326 & 333 & 321 & 312 & 307 & 296 & 295 & 294 & 289 \\
\hline \multicolumn{12}{|l|}{ Ratio of debt service to: } \\
\hline Exports of goods and services & 10 & 8 & 10 & 15 & 15 & 13 & 12 & 11 & 11 & 12 & 13 \\
\hline Central government revenue & 37 & 26 & 33 & 51 & 50 & 43 & 37 & 34 & 33 & 37 & 39 \\
\hline \multicolumn{12}{|l|}{ Rescheduling on Houston terms 1/ } \\
\hline \multicolumn{12}{|l|}{ Ratio of NPV of external debt to: } \\
\hline Exports of goods and services & 128 & 109 & 99 & 103 & 105 & 106 & 107 & 105 & 105 & 106 & 105 \\
\hline Central government revenue & 356 & 320 & 319 & 340 & 339 & 329 & 323 & 310 & 309 & 306 & 301 \\
\hline \multicolumn{12}{|l|}{ Ratio of debt service to: } \\
\hline Exports of goods and services & 10 & 8 & 10 & 11 & 11 & 13 & 12 & 11 & 11 & 12 & 13 \\
\hline Central government revenue & 37 & 26 & 33 & 38 & 38 & 44 & 38 & 35 & 34 & 38 & 40 \\
\hline \multicolumn{12}{|c|}{ Rescheduling on Naples terms (flow restructuring of 2003-04 maturities) } \\
\hline \multicolumn{12}{|l|}{ Ratio of NPV of external debt to: } \\
\hline Exports of goods and services & 128 & 104 & 95 & 99 & 101 & 102 & 103 & 101 & 102 & 103 & 102 \\
\hline Central government revenue & 356 & 307 & 306 & 326 & 326 & 318 & 312 & 300 & 300 & 298 & 293 \\
\hline \multicolumn{12}{|l|}{ Ratio of debt service to: } \\
\hline Exports of goods and services & 10 & 8 & 10 & 11 & 11 & 13 & 12 & 11 & 11 & 12 & 13 \\
\hline Central government revenue & 37 & 26 & 33 & 38 & 37 & 43 & 38 & 34 & 34 & 37 & 39 \\
\hline \multicolumn{12}{|c|}{ Rescheduling on Naples terms (stock-of-debt operation following flow restructuring) } \\
\hline \multicolumn{12}{|l|}{ Ratio of NPV of external debt to: } \\
\hline Exports of goods and services & 128 & 82 & 74 & 78 & 80 & 85 & 89 & 91 & 94 & 96 & 98 \\
\hline Central government revenue & 356 & 242 & 240 & 256 & 258 & 263 & 270 & 269 & 275 & 279 & 279 \\
\hline \multicolumn{12}{|l|}{ Ratio of debt service to: } \\
\hline Exports of goods and services & 10 & 8 & 10 & 11 & 11 & 9 & 8 & 8 & 9 & 10 & 12 \\
\hline Central government revenue & 37 & 26 & 33 & 38 & 37 & 31 & 26 & 25 & 28 & 32 & 35 \\
\hline \multicolumn{12}{|l|}{ Assumptions } \\
\hline Real GDP growth & 1.9 & 3.9 & 1.8 & 2.5 & 2.5 & 2.5 & 2.5 & 2.5 & 2.0 & 2.0 & 2.0 \\
\hline \multicolumn{12}{|l|}{ Growth in external trade: } \\
\hline Exports of goods and services & $\ldots$ & 0.0 & 5.7 & 5.5 & 6.1 & 6.0 & 7.2 & 8.0 & 6.3 & 6.5 & 6.7 \\
\hline Imports of goods and services & $\ldots$ & 5.5 & 3.0 & 5.9 & 10.4 & 5.9 & 4.3 & 4.2 & 3.6 & 5.0 & 6.1 \\
\hline RER change (against US dollar) 2/ & 2.9 & 0.2 & -4.1 & -3.8 & 0.1 & 0.6 & 0.6 & 0.6 & 0.6 & 0.7 & 0.7 \\
\hline FDI (in percent of GDP) & 5.1 & 3.2 & 1.2 & 2.0 & 4.7 & 4.6 & 3.7 & 2.8 & 1.5 & 1.1 & 1.1 \\
\hline Central government revenue (in percent of GDP) & 10.3 & 10.5 & 10.9 & 11.0 & 11.4 & 11.8 & 12.2 & 12.6 & 13.0 & 13.3 & 13.7 \\
\hline
\end{tabular}

Source: Staff projections.

1/ Based on Georgian rescheduling in 2001.

2/ A positive sign means appreciation. 
Appendix Table 12a. Georgia: Medium Term Projections, 2000-2005, Baseline Scenario

\begin{tabular}{|c|c|c|c|c|c|c|}
\hline & $\begin{array}{c}2000 \\
\text { Prelim. }\end{array}$ & 2001 & 2002 & 2003 & 2004 & 2005 \\
\hline \multicolumn{7}{|l|}{ Income and prices } \\
\hline Nominal GDP (millions of lari) & 5,955 & 6,509 & 7,060 & 7,710 & 8,419 & 9,193 \\
\hline Nominal GDP (millions of USD) & 3,013 & 3,255 & 3,362 & 3,466 & 3,718 & 3,998 \\
\hline GDP per capita (USD) & 591 & 651 & 672 & 693 & 744 & 800 \\
\hline Real GDP growth (in percent) & 1.9 & 3.9 & 3.3 & 4.0 & 4.0 & 4.0 \\
\hline Consumer prices (in percent, average) & 4.0 & 4.6 & 4.2 & 5.0 & 5.0 & 5.0 \\
\hline RER change (against USD; percent) & 2.9 & 0.2 & -2.9 & -3.3 & 0.6 & 0.9 \\
\hline \multicolumn{7}{|l|}{ Savings and investment balances (all as share in GDP) } \\
\hline Total investment & 17.5 & 15.0 & 14.4 & 15.4 & 18.0 & 17.9 \\
\hline Public & 1.0 & 1.4 & 1.5 & 1.4 & 1.5 & 1.5 \\
\hline \multicolumn{6}{|l|}{ On-budget investment } & \\
\hline Private & 16.4 & 13.6 & 12.8 & 14.0 & 16.5 & 16.4 \\
\hline Total domestic savings & 12.1 & 8.6 & 9.3 & 10.2 & 11.2 & 10.9 \\
\hline Public & -3.0 & 0.2 & 0.8 & 0.2 & 1.3 & 0.7 \\
\hline Private & 15.1 & 8.4 & 8.5 & 10.0 & 9.9 & 10.2 \\
\hline Foreign savings & 5.4 & 6.4 & 5.1 & 5.2 & 6.8 & 7.0 \\
\hline \multicolumn{7}{|l|}{ General government (all as share in GDP) } \\
\hline Total revenue and grants & 15.3 & 16.7 & 17.7 & 18.3 & 18.8 & 19.1 \\
\hline o/w Grants & 0.3 & 0.9 & 1.0 & 1.1 & 1.1 & 0.8 \\
\hline Total expenditure & 19.4 & 17.9 & 18.4 & 18.3 & 17.7 & 18.7 \\
\hline Non-interest expenditure & 15.4 & 14.3 & 14.6 & 14.6 & 14.0 & 15.3 \\
\hline Interest & 3.0 & 2.2 & 2.3 & 2.2 & 2.1 & 1.9 \\
\hline Capital expenditure plus net lending & 1.0 & 1.4 & 1.5 & 1.5 & 1.6 & 1.6 \\
\hline \multicolumn{7}{|l|}{ Budget balance } \\
\hline Overall budget balance & -4.1 & -1.2 & -0.7 & 0.0 & 1.1 & 0.3 \\
\hline Primary balance & -1.1 & 1.0 & 1.6 & 2.2 & 3.1 & 2.2 \\
\hline \multicolumn{7}{|l|}{ Primary balance excluding investment } \\
\hline \multicolumn{7}{|l|}{ External sector } \\
\hline Exports of GNFS (millions of USD) & 1,136 & 1,153 & 1,237 & 1,323 & 1,423 & 1,531 \\
\hline Imports of GNFS (millions of USD) & 1,412 & 1,490 & 1,556 & 1,656 & 1,836 & 1,955 \\
\hline Gross reserves, excluding pledged (millions of USD) & 109 & 149 & 183 & 220 & 245 & 267 \\
\hline International reserves (months of imports of GNFS) & 0.9 & 1.2 & 1.4 & 1.6 & 1.6 & 1.6 \\
\hline \multicolumn{7}{|l|}{ Debt ratios (in percent) } \\
\hline NPV of public debt-to-exports ratio & 128 & 110 & 99 & 98 & 93 & 89 \\
\hline NPV of public debt-to-revenue ratio & 356 & 312 & 301 & 295 & 273 & 252 \\
\hline Total public debt service to exports ratio & 10 & 8 & 10 & 14 & 14 & 12 \\
\hline Total public debt service to revenue ratio & 36 & 25 & 31 & 45 & 43 & 36 \\
\hline
\end{tabular}


Appendix Table 12b. Georgia: Medium Term Projections, 2000-2005, Low Case Scenario

\begin{tabular}{|c|c|c|c|c|c|c|}
\hline & $\begin{array}{r}2000 \\
\text { Prelim. }\end{array}$ & 2001 & 2002 & 2003 & 2004 & 2005 \\
\hline \multicolumn{7}{|l|}{ Income and prices } \\
\hline Nominal GDP (millions of lari) & 5,955 & 6,509 & 6,958 & 7,488 & 8,059 & 8,674 \\
\hline Nominal GDP (millions of USD) & 3,013 & 3,255 & 3,272 & 3,308 & 3,480 & 3,679 \\
\hline GDP per capita (USD) & 591 & 651 & 654 & 662 & 696 & 736 \\
\hline Real GDP growth (in percent) & 1.9 & 3.9 & 1.8 & 2.5 & 2.5 & 2.5 \\
\hline Consumer prices (in percent, average) & 4.0 & 4.6 & 4.2 & 5.0 & 5.0 & 5.0 \\
\hline RER change (against USD; percent) & 2.9 & 0.2 & -4.1 & -3.8 & 0.1 & 0.6 \\
\hline \multicolumn{7}{|l|}{ Savings and investment balances (all as share in GDP) } \\
\hline Total investment & 17.5 & 13.5 & 12.9 & 14.0 & 16.7 & 16.6 \\
\hline Public & 1.0 & 1.4 & 1.4 & 1.6 & 1.7 & 1.7 \\
\hline Private & 16.4 & 12.1 & 11.5 & 12.4 & 15.0 & 14.9 \\
\hline Total domestic savings & 12.1 & 6.6 & 7.1 & 7.8 & 8.3 & 7.5 \\
\hline Public & -3.0 & 0.2 & 0.4 & 1.6 & 1.7 & 0.6 \\
\hline Private & 15.1 & 6.4 & 6.8 & 6.2 & 6.7 & 6.9 \\
\hline Foreign savings & 5.4 & 6.9 & 5.8 & 6.3 & 8.4 & 9.1 \\
\hline \multicolumn{7}{|l|}{ General government (all as share in GDP) } \\
\hline Total revenue and grants & 15.3 & 16.2 & 17.1 & 17.3 & 17.8 & 18.1 \\
\hline o/w Grants & 0.3 & 0.9 & 1.0 & 1.2 & 1.2 & 0.8 \\
\hline Total expenditure & 19.4 & 17.5 & 18.1 & 17.3 & 17.9 & 19.3 \\
\hline Non-interest expenditure & 15.9 & 14.3 & 14.5 & 13.8 & 14.7 & 15.8 \\
\hline Interest & 3.0 & 2.2 & 2.4 & 2.4 & 2.3 & 2.3 \\
\hline Capital expenditure plus net lending & 0.5 & 1.0 & 1.2 & 1.2 & 0.9 & 1.2 \\
\hline \multicolumn{7}{|l|}{ Budget balance } \\
\hline Overall budget balance & -4.1 & -1.2 & -1.0 & 0.0 & -0.1 & -1.1 \\
\hline Primary balance & -1.1 & 1.0 & 1.4 & 2.4 & 2.2 & 1.1 \\
\hline \multicolumn{7}{|l|}{ External sector } \\
\hline Exports of GNFS (millions of USD) & 1136 & 1136 & 1201 & 1267 & 1344 & 1425 \\
\hline Imports of GNFS (millions of USD) & 1412 & 1490 & 1535 & 1624 & 1793 & 1899 \\
\hline Gross reserves, excluding pledged (millions of USD) & 109 & 140 & 154 & 164 & 155 & 158 \\
\hline International reserves (months of imports of GNFS) & 0.9 & 1.1 & 1.2 & 1.2 & 1.0 & 1.0 \\
\hline \multicolumn{7}{|l|}{ Debt ratios (in percent) } \\
\hline NPV of public debt-to-exports ratio & 128 & 111 & 100 & 101 & 100 & 101 \\
\hline NPV of public debt-to-revenue ratio & 356 & 326 & 326 & 333 & 321 & 312 \\
\hline Total public debt service to exports ratio & 10 & 8 & 10 & 15 & 15 & 13 \\
\hline Total public debt service to revenue ratio & 37 & 26 & 33 & 51 & 50 & 43 \\
\hline
\end{tabular}

Sources: Georgian authorities; and staff estimates. 
Appendix Table 13a. Kyrgyz Republic: Debt Sustainability Analysis--Baseline Scenario (In percent)

\begin{tabular}{|c|c|c|c|c|c|c|c|c|c|c|c|}
\hline & 2000 & 2001 & 2002 & 2003 & 2004 & 2005 & 2006 & 2007 & 2008 & 2009 & 2010 \\
\hline \multicolumn{12}{|l|}{ No debt relief } \\
\hline \multicolumn{12}{|l|}{ Ratio of NPV of external debt to: } \\
\hline Exports of goods and services & 198 & 211 & 212 & 205 & 199 & 191 & 185 & 177 & 167 & 157 & 147 \\
\hline State government revenue & 576 & 491 & 433 & 368 & 322 & 300 & 279 & 264 & 246 & 228 & 213 \\
\hline \multicolumn{12}{|l|}{ Ratio of debt service to: } \\
\hline Exports of goods and services & 28 & 32 & 30 & 31 & 24 & 20 & 19 & 16 & 17 & 16 & 14 \\
\hline State government revenue $1 /$ & 41 & 30 & 28 & 31 & 29 & 27 & 25 & 23 & 25 & 24 & 21 \\
\hline \multicolumn{12}{|c|}{ Previous + rescheduling on Houston terms (flow restructuring; 12/2001-12/2010) } \\
\hline \multicolumn{12}{|l|}{ Ratio of NPV of external debt to: } \\
\hline Exports of goods and services & 197 & 205 & 207 & 199 & 197 & 191 & 186 & 180 & 173 & 165 & 156 \\
\hline State government revenue & 575 & 476 & 423 & 357 & 319 & 299 & 282 & 269 & 254 & 239 & 226 \\
\hline \multicolumn{12}{|l|}{ Ratio of debt service to: } \\
\hline Exports of goods and services & 28 & 32 & 23 & 24 & 17 & 14 & 14 & 11 & 13 & 12 & 12 \\
\hline State government revenue $1 /$ & 41 & 30 & 17 & 18 & 18 & 18 & 17 & 17 & 18 & 18 & 18 \\
\hline \multicolumn{12}{|c|}{ Rescheduling on Naples terms (flow rescheduling 12-2001 12-2004; 12/2004 stock-of-debt operation) } \\
\hline \multicolumn{12}{|l|}{ Ratio of NPV of external debt to: } \\
\hline Exports of goods and services & 197 & 206 & 204 & 198 & 167 & 165 & 160 & 154 & 147 & 138 & 130 \\
\hline State government revenue & 575 & 478 & 418 & 355 & 271 & 259 & 243 & 231 & 215 & 201 & 188 \\
\hline \multicolumn{12}{|l|}{ Ratio of debt service to: } \\
\hline Exports of goods and services & 28 & 32 & 23 & 23 & 16 & 15 & 15 & 12 & 13 & 13 & 12 \\
\hline State government revenue 1/ & 41 & 30 & 17 & 18 & 17 & 19 & 18 & 17 & 19 & 18 & 17 \\
\hline \multicolumn{12}{|l|}{ Assumptions } \\
\hline Real GDP growth & 5.0 & 5.0 & 4.5 & 4.5 & 4.2 & 4.0 & 4.2 & 4.4 & 4.3 & 4.3 & 4.3 \\
\hline \multicolumn{12}{|l|}{ Growth in external trade: } \\
\hline Exports of goods and services & 8.6 & -4.3 & 2.9 & 3.5 & 2.6 & 9.0 & 8.6 & 8.8 & 8.6 & 10.4 & 11.3 \\
\hline Imports of goods and services & -7.2 & -5.3 & 4.9 & 6.4 & 3.3 & 4.6 & 6.0 & 9.1 & 8.9 & 9.9 & 10.1 \\
\hline RER change (against US dollar) 2/ & 6.1 & 2.0 & 4.4 & 2.4 & 1.9 & 1.8 & 1.4 & 1.7 & 1.6 & 1.6 & 1.6 \\
\hline FDI (in percent of GDP) & 2.2 & 2.4 & 2.1 & 3.0 & 2.9 & 2.6 & 2.7 & 2.8 & 3.3 & 3.3 & 2.8 \\
\hline Central government revenue (in percent of GDP) & 14.9 & 16.4 & 16.8 & 17.1 & 17.8 & 17.6 & 17.8 & 17.8 & 17.8 & 17.8 & 17.8 \\
\hline
\end{tabular}

Source: Staff projections.

1/ Excluding Kumtor-related debt service (see EBS/01/187).

2/ A positive sign means appreciation. 
Appendix Table 13b. Kyrgyz Republic: Debt Sustainability Analysis--Low-Case Scenario

(In percent)

\begin{tabular}{|c|c|c|c|c|c|c|c|c|c|c|c|}
\hline & 2000 & 2001 & 2002 & 2003 & 2004 & 2005 & 2006 & 2007 & 2008 & 2009 & 2010 \\
\hline \multicolumn{12}{|l|}{ No debt relief } \\
\hline \multicolumn{12}{|l|}{ Ratio of NPV of external debt to: } \\
\hline Exports of goods and services & 198 & 210 & 211 & 209 & 210 & 208 & 206 & 202 & 198 & 194 & 190 \\
\hline State government revenue & 576 & 487 & 441 & 388 & 359 & 341 & 330 & 324 & 315 & 308 & 304 \\
\hline \multicolumn{12}{|l|}{ Ratio of debt service to: } \\
\hline Exports of goods and services & 28 & 32 & 30 & 31 & 25 & 22 & 21 & 17 & 19 & 19 & 17 \\
\hline State government revenue 1/ & 41 & 30 & 28 & 33 & 33 & 30 & 29 & 28 & 30 & 30 & 28 \\
\hline \multicolumn{12}{|c|}{ Previous + rescheduling on Houston terms (flow restructuring; 12/2001-12/2010) } \\
\hline \multicolumn{12}{|l|}{ Ratio of NPV of external debt to: } \\
\hline Exports of goods and services & 197 & 203 & 206 & 203 & 205 & 205 & 205 & 204 & 203 & 201 & 199 \\
\hline State government revenue & 575 & 472 & 431 & 376 & 352 & 336 & 330 & 327 & 322 & 319 & 318 \\
\hline \multicolumn{12}{|l|}{ Ratio of debt service to: } \\
\hline Exports of goods and services & 28 & 32 & 23 & 24 & 18 & 15 & 16 & 13 & 14 & 14 & 15 \\
\hline State government revenue 1/ & 41 & 29 & 18 & 19 & 19 & 20 & 20 & 20 & 22 & 23 & 23 \\
\hline \multicolumn{12}{|c|}{ Rescheduling on Naples terms (flow rescheduling 12-2001 12-2004; 12/2004 stock-of-debt operation) } \\
\hline \multicolumn{12}{|l|}{ Ratio of NPV of external debt to: } \\
\hline Exports of goods and services & 197 & 204 & 204 & 202 & 175 & 178 & 177 & 175 & 173 & 170 & 168 \\
\hline State government revenue & 575 & 473 & 426 & 374 & 299 & 291 & 284 & 280 & 275 & 270 & 268 \\
\hline \multicolumn{12}{|l|}{ Ratio of debt service to: } \\
\hline Exports of goods and services & 28 & 32 & 23 & 24 & 17 & 16 & 16 & 13 & 15 & 15 & 14 \\
\hline State government revenue 1 / & 41 & 29 & 18 & 19 & 18 & 21 & 21 & 20 & 23 & 24 & 23 \\
\hline \multicolumn{12}{|l|}{ Assumptions } \\
\hline Real GDP growth & 5.0 & 5.0 & 2.5 & 2.5 & 2.2 & 2.0 & 2.2 & 2.4 & 2.3 & 2.3 & 2.3 \\
\hline \multicolumn{12}{|l|}{ Growth in external trade: } \\
\hline Exports of goods and services & 8.6 & -4.3 & 0.9 & 1.5 & 0.6 & 7.0 & 5.6 & 5.8 & 5.5 & 7.4 & 8.2 \\
\hline Imports of goods and services & -7.2 & -5.3 & 3.9 & 5.4 & 2.3 & 3.6 & 5.0 & 8.1 & 7.9 & 8.9 & 9.1 \\
\hline RER change (against US dollar) 2/ & 6.1 & 2.0 & 3.3 & 1.4 & 1.0 & 0.9 & 0.5 & 0.8 & 0.8 & 0.8 & 0.8 \\
\hline FDI (in percent of GDP) & 2.2 & 2.4 & 1.1 & 2.0 & 1.9 & 1.6 & 1.7 & 1.8 & 2.3 & 2.3 & 1.8 \\
\hline Central government revenue (in percent of GDP) & 14.9 & 16.4 & 16.8 & 17.2 & 17.6 & 17.8 & 17.8 & 17.8 & 17.8 & 17.8 & 17.8 \\
\hline
\end{tabular}

Source: Staff projections.

1/ Excluding Kumtor-related debt service (see EBS/01/187). 
Appendix Table 14a. Kyrgyz Republic: Medium-Term Projections, 2000-2005, Baseline Scenario

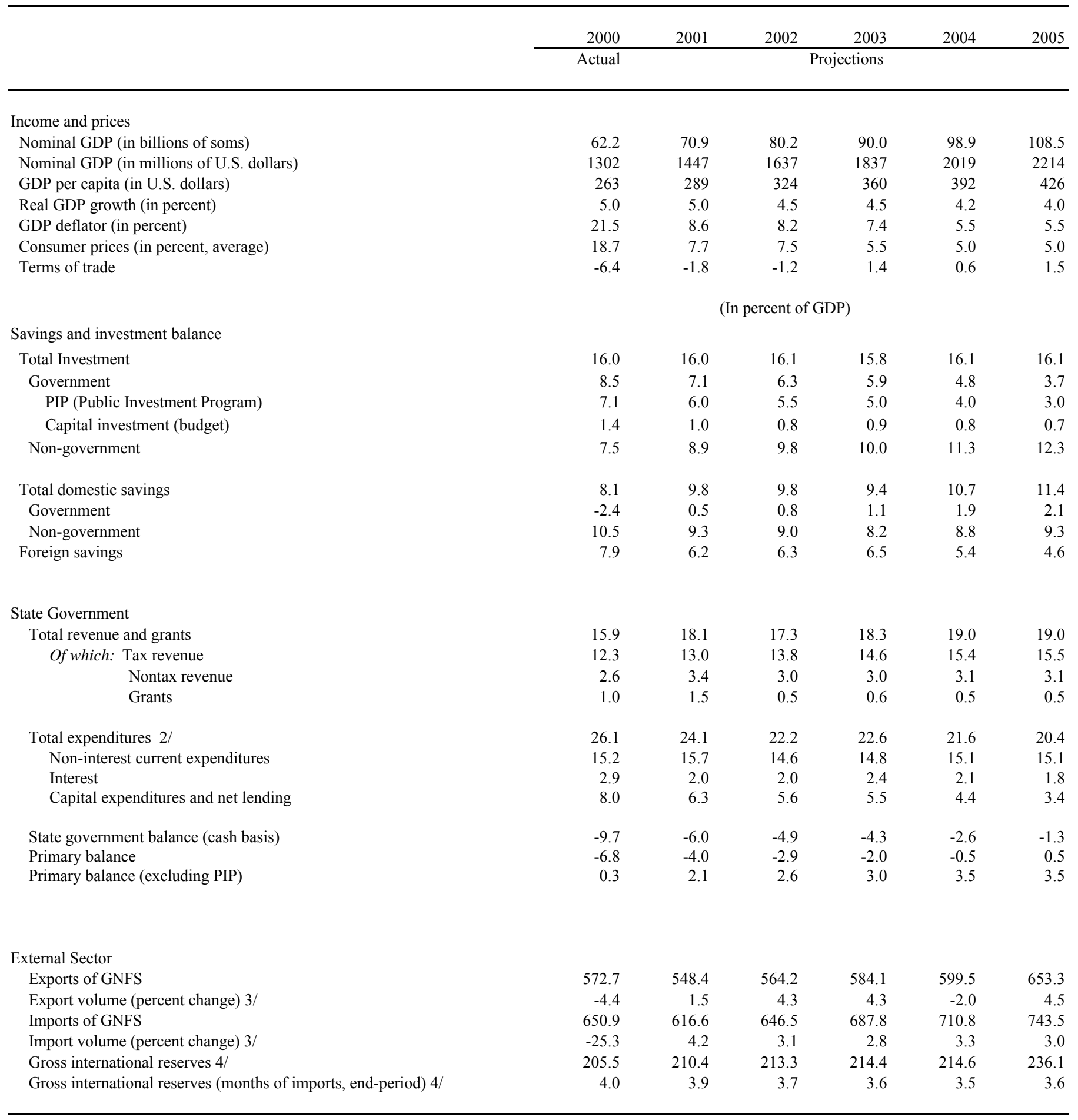

Sources: Kyrgyz authorities; and staff estimates.

1/ Excluding transfers from government.

2/ Includes PIP and excludes transfers to Social Fund.

3/ In U.S. dollars; includes the operations of the Kumtor gold mining company.

4/ Gross reserves exclude international reserves of NBKR that are pledged or blocked. 
Appendix Table 14b. Kyrgyz Republic: Medium-Term Projections, 2000-2005, Low Case Scenario

\begin{tabular}{|c|c|c|c|c|c|c|}
\hline & 2000 & 2001 & 2002 & 2003 & 2004 & 2005 \\
\hline & Actual & \multicolumn{5}{|c|}{ Projections } \\
\hline \multicolumn{7}{|l|}{ Income and prices } \\
\hline Nominal GDP (in billions of soms) & 62.2 & 70.9 & 78.8 & 86.8 & 93.7 & 100.9 \\
\hline Nominal GDP (in millions of U.S. dollars) & 1302 & 1447 & 1592 & 1737 & 1856 & 1979 \\
\hline GDP per capita (in U.S. dollars) & 263 & 289 & 315 & 341 & 360 & 380 \\
\hline Real GDP growth (in percent) & 5.0 & 5.0 & 2.5 & 2.5 & 2.2 & 2.0 \\
\hline GDP deflator (in percent) & 21.5 & 8.6 & 8.2 & 7.4 & 5.5 & 5.5 \\
\hline Consumer prices (in percent, average) & 18.7 & 7.7 & 7.5 & 5.5 & 5.0 & 5.0 \\
\hline Terms of trade & -6.4 & -1.8 & -1.2 & 1.4 & 0.6 & 1.5 \\
\hline & \multicolumn{6}{|c|}{ (In percent of GDP) } \\
\hline \multicolumn{7}{|l|}{ Savings and investment balance } \\
\hline Total Investment & 16.0 & 16.0 & 16.1 & 15.8 & 16.1 & 16.1 \\
\hline Government & 8.5 & 7.1 & 6.3 & 5.9 & 4.8 & 3.7 \\
\hline PIP (Public Investment Program) & 7.1 & 6.0 & 5.5 & 5.0 & 4.0 & 3.0 \\
\hline Capital investment (budget) & 1.4 & 1.0 & 0.8 & 0.9 & 0.8 & 0.7 \\
\hline Non-government & 7.5 & 8.9 & 9.8 & 10.0 & 11.3 & 12.3 \\
\hline Total domestic savings & 8.1 & 9.8 & 9.5 & 8.8 & 9.9 & 10.4 \\
\hline Government & -2.4 & 0.5 & 0.8 & 1.1 & 1.9 & 2.1 \\
\hline Non-government & 10.5 & 9.3 & 8.7 & 7.7 & 8.0 & 8.3 \\
\hline Foreign savings & 7.9 & 6.2 & 6.6 & 7.0 & 6.1 & 5.7 \\
\hline \multicolumn{7}{|l|}{ State Government } \\
\hline Total revenue and grants & 15.9 & 18.1 & 17.5 & 18.3 & 18.5 & 19.3 \\
\hline Of which: Tax revenue & 12.3 & 13.0 & 14.0 & 14.7 & 14.9 & 15.7 \\
\hline Nontax revenue & 2.6 & 3.4 & 3.0 & 3.0 & 3.1 & 3.1 \\
\hline Grants & 1.0 & 1.5 & 0.5 & 0.6 & 0.5 & 0.5 \\
\hline Total expenditures $2 /$ & 26.1 & 24.1 & 22.1 & 22.2 & 20.6 & 19.7 \\
\hline Non-interest current expenditures & 15.2 & 15.7 & 14.5 & 14.4 & 14.1 & 14.4 \\
\hline Interest & 2.9 & 2.0 & 2.0 & 2.4 & 2.1 & 1.8 \\
\hline Capital expenditures and net lending & 8.0 & 6.3 & 5.6 & 5.5 & 4.4 & 3.4 \\
\hline State government balance (cash basis) & -9.7 & -6.0 & -4.6 & -3.9 & -2.1 & -0.4 \\
\hline Primary balance & -6.8 & -4.0 & -2.6 & -1.6 & 0.0 & 1.4 \\
\hline Primary balance (excluding PIP) & 0.3 & 2.1 & 2.9 & 3.4 & 4.0 & 4.4 \\
\hline \multicolumn{7}{|l|}{ External Sector } \\
\hline Exports of GNFS & 572.7 & 548.4 & 553.3 & 561.7 & 565.2 & 604.7 \\
\hline Imports of GNFS & 650.9 & 616.6 & 640.4 & 674.8 & 690.6 & 715.5 \\
\hline Gross international reserves $3 /$ & 205.5 & 210.4 & 208.1 & 207.2 & 208.7 & 225.4 \\
\hline Gross international reserves (months of imports, end-period) 3/ & 4.0 & 3.9 & 3.7 & 3.6 & 3.5 & 3.6 \\
\hline
\end{tabular}

Sources: Kyrgyz authorities; and staff estimates.

1/ Excluding transfers from government.

2/ Includes PIP and excludes transfers to Social Fund.

3/ Gross reserves exclude international reserves of NBKR that are pledged or blocked. 
Appendix Table 15a. Moldova: Debt Sustainability Analysis--Baseline Scenario (In percent)

\begin{tabular}{|c|c|c|c|c|c|c|c|c|c|c|c|}
\hline & 2000 & 2001 & 2002 & 2003 & 2004 & 2005 & 2006 & 2007 & 2008 & 2009 & 2010 \\
\hline \multicolumn{12}{|l|}{ No debt relief } \\
\hline \multicolumn{12}{|l|}{ Ratio of NPV of external debt to: } \\
\hline Exports of goods and services & 139 & 114 & 103 & 93 & 81 & 70 & 61 & 55 & 48 & 41 & 36 \\
\hline Central government revenue & 380 & 350 & 298 & 265 & 236 & 209 & 187 & 170 & 152 & 134 & 119 \\
\hline \multicolumn{12}{|l|}{ Ratio of debt service to: } \\
\hline Exports of goods and services & 15 & 18 & 21 & 15 & 12 & 11 & 9 & 6 & 7 & 6 & 5 \\
\hline Central government revenue & 42 & 54 & 61 & 42 & 35 & 32 & 26 & 20 & 21 & 21 & 18 \\
\hline \multicolumn{12}{|c|}{ Debt relief under Paris Club flow rescheduling (q2 2002-2003) } \\
\hline \multicolumn{12}{|l|}{ Ratio of NPV of external debt to: } \\
\hline Exports of goods and services & 139 & 114 & 97 & 91 & 78 & 65 & 56 & 50 & 43 & 37 & 33 \\
\hline Central government revenue & 380 & 350 & 279 & 259 & 226 & 194 & 171 & 154 & 138 & 122 & 109 \\
\hline \multicolumn{12}{|l|}{ Ratio of debt service to: } \\
\hline Exports of goods and services & 15 & 18 & 11 & 9 & 12 & 11 & 9 & 7 & 6 & 6 & 5 \\
\hline Central government revenue & 42 & 54 & 31 & 25 & 35 & 32 & 27 & 20 & 20 & 19 & 16 \\
\hline \multicolumn{12}{|c|}{ Rescheduling on Houston terms flow rescheduling (q2 2002-2003) } \\
\hline \multicolumn{12}{|l|}{ Ratio of NPV of external debt to: } \\
\hline Exports of goods and services & 139 & 114 & 108 & 100 & 86 & 72 & 62 & 55 & 48 & 42 & 37 \\
\hline Central government revenue & 380 & 350 & 311 & 284 & 249 & 215 & 190 & 172 & 154 & 137 & 123 \\
\hline \multicolumn{12}{|l|}{ Ratio of debt service to: } \\
\hline Exports of goods and services & 15 & 18 & 12 & 9 & 13 & 11 & 9 & 7 & 7 & 6 & 5 \\
\hline Central government revenue & 42 & 54 & 35 & 27 & 37 & 34 & 28 & 22 & 21 & 20 & 17 \\
\hline \multicolumn{12}{|c|}{ Rescheduling on Naples terms (stock-of-debt operation q2 2002) } \\
\hline \multicolumn{12}{|l|}{ Ratio of NPV of external debt to: } \\
\hline Exports of goods and services & 139 & 114 & 82 & 75 & 66 & 59 & 53 & 48 & 43 & 38 & 34 \\
\hline Central government revenue & 380 & 350 & 237 & 213 & 193 & 175 & 162 & 149 & 137 & 124 & 113 \\
\hline \multicolumn{12}{|l|}{ Ratio of debt service to: } \\
\hline Exports of goods and services & 15 & 18 & 13 & 10 & 8 & 6 & 5 & 5 & 5 & 5 & 4 \\
\hline Central government revenue & 42 & 54 & 36 & 27 & 23 & 19 & 17 & 16 & 16 & 16 & 14 \\
\hline \multicolumn{12}{|l|}{ Assumptions } \\
\hline Real GDP growth & 1.9 & 5.0 & 4.8 & 5.0 & 5.0 & 5.0 & 4.0 & 4.0 & 4.0 & 4.0 & 4.0 \\
\hline \multicolumn{12}{|l|}{ Growth in external trade: } \\
\hline Exports of goods and services & 5.8 & 19.5 & 7.7 & 12.0 & 12.0 & 12.1 & 11.6 & 10.9 & 11.5 & 11.0 & 11.1 \\
\hline Imports of goods and services & 31.0 & 8.7 & 8.7 & 10.0 & 10.8 & 10.2 & 9.4 & 9.6 & 9.0 & 8.9 & 9.2 \\
\hline RER change (against US dollar) 1/ & 7.5 & 2.0 & 2.0 & 2.0 & 2.0 & 2.0 & 2.0 & 2.0 & 2.0 & 2.0 & 2.0 \\
\hline FDI (in percent of GDP) & 8.9 & 9.4 & 7.8 & 6.1 & 6.2 & 6.2 & 6.2 & 6.2 & 6.2 & 5.8 & 5.8 \\
\hline Central government revenue (in percent of GD & 16.4 & 15.4 & 16.0 & 16.5 & 16.5 & 16.5 & 16.5 & 16.5 & 16.5 & 16.5 & 16.5 \\
\hline
\end{tabular}

Source: staff projections.

1/ A positive sign means appreciation. 
Appendix Table 15b. Moldova: Debt Sustainability Analysis--Low-Case Scenario (In percent)

$2000 \quad 20012002 \quad 2003 \quad 2004 \quad 2005 \quad 2006 \quad 2007 \quad 2008 \quad 2009 \quad 2010$

No debt relief

\begin{tabular}{|c|c|c|c|c|c|c|c|c|c|c|c|}
\hline \multicolumn{12}{|l|}{ Ratio of NPV of external debt to: } \\
\hline Exports of goods and services & 139 & 114 & 106 & 99 & 93 & 87 & 82 & 78 & 73 & 68 & 63 \\
\hline Central government revenue & 380 & 350 & 312 & 303 & 289 & 275 & 263 & 255 & 244 & 230 & 217 \\
\hline \multicolumn{12}{|l|}{ Ratio of debt service to: } \\
\hline Exports of goods and services & 15 & 18 & 21 & 15 & 13 & 12 & 10 & 8 & 9 & 9 & 9 \\
\hline Central government revenue & 42 & 54 & 63 & 46 & 41 & 39 & 34 & 27 & 30 & 32 & 30 \\
\hline
\end{tabular}

Debt relief under Paris Club flow rescheduling (q2 2002-2003)

Ratio of NPV of external debt to:

$\begin{array}{llllllllllll}\text { Exports of goods and services } & 139 & 114 & 97 & 93 & 84 & 75 & 69 & 64 & 59 & 54 & 50\end{array}$

Central government revenue

$\begin{array}{lllllllllll}380 & 350 & 287 & 286 & 262 & 239 & 221 & 209 & 196 & 183 & 173\end{array}$

Ratio of debt service to:

$\begin{array}{llllllllllll}\text { Exports of goods and services } & 15 & 18 & 11 & 9 & 13 & 12 & 10 & 8 & 8 & 8 & 7\end{array}$

$\begin{array}{llllllllllll}\text { Central government revenue } & 42 & 54 & 32 & 28 & 41 & 39 & 34 & 27 & 28 & 28 & 25\end{array}$

Rescheduling on Houston terms flow rescheduling (q2 2002-2003)

$\begin{array}{lrrrrrrrrrrr}\text { Ratio of NPV of external debt to: } & 139 & 114 & 109 & 103 & 93 & 84 & 76 & 71 & 66 & 61 & 56 \\ \quad \begin{array}{l}\text { Exports of goods and services } \\ \text { Central government revenue }\end{array} & 380 & 350 & 320 & 314 & 289 & 264 & 245 & 233 & 219 & 205 & 193 \\ & & & & & & & & & & & \\ & & & & & & & & & & 9 & 8 \\ \text { Ratio of debt service to: } & 15 & 18 & 12 & 10 & 14 & 13 & 11 & 9 & 9 & 9 & 8 \\ \quad \begin{array}{l}\text { Exports of goods and services } \\ \text { Central government revenue }\end{array} & 42 & 54 & 36 & 29 & 43 & 41 & 36 & 29 & 30 & 29 & 26\end{array}$

Rescheduling on Naples terms (stock-of-debt operation q2 2002)

Ratio of NPV of external debt to: Exports of goods and services Central government revenue

$\begin{array}{rrrrrrrrrrr}139 & 114 & 83 & 77 & 72 & 68 & 65 & 62 & 59 & 55 & 52 \\ 380 & 350 & 244 & 235 & 224 & 215 & 209 & 203 & 196 & 186 & 179\end{array}$

Ratio of debt service to:

Exports of goods and services

Central government revenue

$\begin{array}{rrrrrrrrrrr}15 & 18 & 13 & 10 & 9 & 7 & 7 & 6 & 7 & 7 & 6 \\ 42 & 54 & 37 & 30 & 27 & 23 & 21 & 21 & 22 & 23 & 21\end{array}$

Assumptions

$\begin{array}{lrrrrrrrrrrr}\text { Real GDP growth } & 1.9 & 5.0 & 2.0 & 2.0 & 2.0 & 2.0 & 2.0 & 2.0 & 2.0 & 2.0 & 2.0 \\ \text { Growth in external trade: } & & & & & & & & & & & \\ \quad \text { Exports of goods and services } & 5.8 & 19.5 & 7.0 & 9.5 & 6.3 & 6.3 & 6.3 & 6.2 & 6.2 & 6.2 & 6.2 \\ \quad \text { Imports of goods and services } & 31.0 & 8.7 & 6.5 & 6.8 & 6.5 & 6.5 & 6.2 & 5.1 & 5.1 & 5.1 & 5.1 \\ \text { RER change (against US dollar) 1/ } & 7.5 & 2.0 & 1.7 & 0.0 & 0.0 & 0.0 & 0.0 & 0.0 & 0.0 & 0.0 & 0.0 \\ \text { FDI (in percent of GDP) } & 8.9 & 9.4 & 3.9 & 4.1 & 4.2 & 4.2 & 4.2 & 4.2 & 4.2 & 4.2 & 4.2 \\ \text { Central government revenue (in percent of GDP) } & 16.4 & 15.4 & 16.0 & 16.0 & 16.0 & 16.0 & 16.0 & 16.0 & 16.0 & 16.0 & 16.0\end{array}$

Source: staff projections.

1/ A positive sign means appreciation. 
Appendix Table 16a. Moldova: Medium-Term Projections, 2000-2005, Baseline Scenario

\begin{tabular}{|c|c|c|c|c|c|c|}
\hline & $\begin{array}{r}2000 \\
\text { Prelim. }\end{array}$ & 2001 & 2002 & 2003 & 2004 & 2005 \\
\hline \multicolumn{7}{|l|}{ Income and prices } \\
\hline Nominal GDP (units) & 17,785 & 20,882 & 24,075 & 27,812 & 32,131 & 37,108 \\
\hline Nominal GDP (millions of USD) & 1,430 & 1,616 & 1,784 & 1,959 & 2,151 & 2,361 \\
\hline GDP per capita (USD) & 397 & 449 & 496 & 544 & 598 & 656 \\
\hline Real GDP growth (in percent) & 1.9 & 5.0 & 4.8 & 5.0 & 5.0 & 5.0 \\
\hline Consumer prices (in percent, average) & 31.8 & 12.8 & 10.0 & 10.0 & 10.0 & 10.0 \\
\hline RER change (against USD; percent) & 7.7 & 5.5 & 2.7 & 2.0 & 2.0 & 2.0 \\
\hline \multicolumn{7}{|l|}{ Savings and investment balances (all as share in GDP) } \\
\hline Total investment & 26.4 & 24.7 & 25.6 & 26.7 & 27.2 & 27.9 \\
\hline Public & 2.2 & 1.8 & 2.2 & 2.4 & 2.4 & 2.4 \\
\hline On-budget investment & 1.0 & 0.7 & 1.1 & 1.4 & 1.4 & 1.4 \\
\hline Other public investment & 1.2 & 1.2 & 1.1 & 0.9 & 0.9 & 0.9 \\
\hline Private & 24.2 & 22.9 & 23.4 & 24.3 & 24.8 & 25.5 \\
\hline Total domestic savings & 18.0 & 17.4 & 17.7 & 18.9 & 20.6 & 22.1 \\
\hline Public & 0.2 & 0.0 & 0.0 & 0.4 & 0.5 & 0.5 \\
\hline Private & 17.8 & 17.4 & 17.7 & 18.5 & 20.1 & 21.6 \\
\hline Foreign savings & 8.4 & 7.3 & 7.9 & 7.8 & 6.6 & 5.8 \\
\hline \multicolumn{7}{|l|}{ General government (all as share in GDP) } \\
\hline Total revenue and grants & 27.6 & 26.5 & 26.0 & 25.7 & 25.6 & 25.7 \\
\hline o/w Grants & 0.7 & 0.6 & 0.0 & 0.0 & 0.0 & 0.0 \\
\hline Total expenditure & 29.6 & 28.3 & 28.2 & 27.8 & 27.5 & 27.6 \\
\hline Non-interest expenditure & 23.9 & 23.5 & 24.2 & 24.4 & 24.2 & 24.2 \\
\hline Interest & 5.7 & 4.8 & 4.0 & 3.4 & 3.4 & 3.4 \\
\hline Capital expenditure plus net lending & 2.2 & 1.8 & 2.2 & 2.4 & 2.4 & 2.4 \\
\hline \multicolumn{7}{|l|}{ Budget balance } \\
\hline Overall budget balance & -2.0 & -1.8 & -2.2 & -2.0 & -1.9 & -1.9 \\
\hline Primary balance & 3.7 & 3.0 & 1.8 & 1.4 & 1.5 & 1.4 \\
\hline Primary balance excluding investment & 5.9 & 4.8 & 4.0 & 3.7 & 3.9 & 3.8 \\
\hline Central government revenue (excluding grants) & 16.4 & 15.5 & 16.0 & 16.5 & 16.5 & 16.5 \\
\hline \multicolumn{7}{|l|}{ External sector } \\
\hline Exports of GNFS (millions of USD) & 641 & 765 & 824 & 922 & 1,033 & 1,158 \\
\hline Imports of GNFS (millions of USD) & 990 & 1,076 & 1,170 & 1,287 & 1,426 & 1,571 \\
\hline Gross reserves, excluding pledged (millions of USD) & 218 & 253 & 294 & 375 & 416 & 458 \\
\hline International reserves (months of imports of GNFS) & 2.6 & 2.8 & 3.0 & 3.5 & 3.5 & 3.5 \\
\hline \multicolumn{7}{|l|}{ Debt ratios (in percent) } \\
\hline NPV of public debt-to-exports of GNFS ratio & 139 & 114 & 103 & 93 & 81 & 70 \\
\hline NPV of public debt-to-central government revenue ratio & 380 & 350 & 298 & 265 & 236 & 209 \\
\hline Total public debt service to exports of GNFS ratio & 15 & 18 & 21 & 15 & 12 & 11 \\
\hline Total public debt service to central government revenue ratio & 42 & 54 & 61 & 42 & 35 & 32 \\
\hline
\end{tabular}

Sources: Moldovan authorities; and staff estimates. 
Appendix Table 16b. Moldova: Medium-Term Projections, 2000-2005, Low Case Scenario

\begin{tabular}{|c|c|c|c|c|c|c|}
\hline & $\begin{array}{r}2000 \\
\text { Prelim. }\end{array}$ & 2001 & 2002 & 2003 & 2004 & 2005 \\
\hline \multicolumn{7}{|l|}{ Income and prices } \\
\hline Nominal GDP (units) & 17,785 & 20,882 & 23,432 & 26,295 & 29,511 & 33,109 \\
\hline Nominal GDP (millions of USD) & 1,430 & 1,616 & 1,734 & 1,828 & 1,912 & 1,999 \\
\hline GDP per capita (USD) & 397 & 449 & 482 & 508 & 531 & 555 \\
\hline Real GDP growth (in percent) & 1.9 & 5.0 & 2.0 & 2.0 & 2.0 & 2.0 \\
\hline Consumer prices (in percent, average) & 31.8 & 12.8 & 10.0 & 10.0 & 10.0 & 10.0 \\
\hline RER change (against USD; percent) & 7.7 & 5.5 & 2.6 & 0.8 & 0.0 & 0.0 \\
\hline \multicolumn{7}{|l|}{ Savings and investment balances (all as share in GDP) } \\
\hline Total investment & 26.4 & 24.7 & 25.1 & 25.5 & 25.4 & 25.4 \\
\hline Public & 2.2 & 1.8 & 2.2 & 2.6 & 2.5 & 2.5 \\
\hline On-budget investment & 1.0 & 0.7 & 0.9 & 1.5 & 1.5 & 1.5 \\
\hline Other public investment & 1.2 & 1.2 & 1.3 & 1.1 & 1.0 & 1.0 \\
\hline Private & 24.2 & 22.9 & 22.9 & 22.9 & 22.9 & 22.9 \\
\hline Total domestic savings & 18.0 & 17.4 & 18.0 & 19.1 & 20.1 & 20.3 \\
\hline Public & 0.2 & 0.0 & -0.4 & -0.4 & -0.6 & -0.5 \\
\hline Private & 17.8 & 17.4 & 18.5 & 19.6 & 20.7 & 20.8 \\
\hline Foreign savings & 8.4 & 7.3 & 7.1 & 6.4 & 5.3 & 5.1 \\
\hline \multicolumn{7}{|l|}{ Central government (all as share in GDP) 1 / } \\
\hline Total revenue and grants & 27.6 & 26.5 & 25.6 & 25.6 & 25.5 & 25.4 \\
\hline $\mathrm{o} / \mathrm{w}$ Grants & 0.7 & 0.6 & 0.0 & 0.0 & 0.0 & 0.0 \\
\hline Total expenditure & 29.6 & 28.3 & 28.2 & 28.6 & 28.6 & 28.4 \\
\hline Non-interest expenditure & 23.9 & 23.5 & 24.2 & 24.6 & 24.6 & 24.5 \\
\hline Interest & 5.7 & 4.8 & 4.1 & 4.0 & 4.0 & 3.9 \\
\hline Capital expenditure plus net lending & 2.2 & 1.8 & 2.2 & 2.6 & 2.5 & 2.5 \\
\hline \multicolumn{7}{|l|}{ Budget balance } \\
\hline Overall budget balance & -2.0 & -1.8 & -2.7 & -3.1 & -3.1 & -3.0 \\
\hline Primary balance & 3.7 & 3.0 & 1.4 & 1.0 & 0.9 & 0.9 \\
\hline Primary balance excluding investment & 5.9 & 4.8 & 3.6 & 3.6 & 3.4 & 3.4 \\
\hline Central government revenue (excluding grants) & 16.4 & 15.5 & 16.0 & 16.5 & 16.5 & 16.5 \\
\hline \multicolumn{7}{|l|}{ External sector } \\
\hline Exports of GNFS (millions of USD) & 641 & 765 & 819 & 896 & 953 & 1,013 \\
\hline Imports of GNFS (millions of USD) & 990 & 1,076 & 1,146 & 1,224 & 1,303 & 1,388 \\
\hline Gross reserves, excluding pledged (millions of USD) & 218 & 253 & 293 & 357 & 380 & 405 \\
\hline International reserves (months of imports of GNFS) & 2.6 & 2.8 & 3.1 & 3.5 & 3.5 & 3.5 \\
\hline \multicolumn{7}{|l|}{ Debt ratios (in percent) } \\
\hline NPV of public debt-to-exports of GNFS ratio & 139.0 & 113.8 & 105.7 & 98.9 & 92.7 & 86.8 \\
\hline NPV of public debt-to-central government revenue ratio & 379.5 & 349.9 & 311.8 & 303.1 & 288.8 & 274.8 \\
\hline Total public debt service to exports of GNFS ratio & 15.3 & 17.5 & 21.4 & 15.1 & 13.1 & 12.4 \\
\hline Total public debt service to central government revenue ratio & 41.9 & 53.8 & 63.2 & 46.4 & 40.9 & 39.3 \\
\hline
\end{tabular}

Sources: Moldovan authorities; and staff estimates. 
Appendix Table 17a. Tajikistan: Debt Sustainability Analysis--Baseline Scenario (In percent)

\begin{tabular}{|c|c|c|c|c|c|c|c|c|c|c|c|}
\hline & 2000 & 2001 & 2002 & 2003 & 2004 & 2005 & 2006 & 2007 & 2008 & 2009 & 2010 \\
\hline \multicolumn{12}{|l|}{ No debt relief } \\
\hline \multicolumn{12}{|l|}{ Ratio of NPV of external debt to: } \\
\hline Exports of goods and services & 137 & 128 & 128 & 130 & 127 & 128 & 118 & 108 & 100 & 93 & 89 \\
\hline Central government revenue & 450 & 370 & 330 & 326 & 321 & 317 & 283 & 247 & 219 & 196 & 179 \\
\hline \multicolumn{12}{|l|}{ Ratio of debt service to: } \\
\hline Exports of goods and services & 10 & 18 & 43 & 38 & 35 & 31 & 25 & 22 & 21 & 19 & 18 \\
\hline Central government revenue & 35 & 53 & 50 & 41 & 40 & 35 & 34 & 31 & 30 & 26 & 25 \\
\hline \multicolumn{12}{|c|}{ Rescheduling on Naples terms (flow rescheduling with the consolidation period covering H2/2002-H1/2005) } \\
\hline \multicolumn{12}{|l|}{ Ratio of NPV of external debt to: } \\
\hline Exports of goods and services & 137 & 128 & 107 & 122 & 131 & 141 & 134 & 126 & 119 & 113 & 109 \\
\hline Central government revenue & 450 & 370 & 277 & 307 & 331 & 349 & 320 & 287 & 260 & 237 & 220 \\
\hline \multicolumn{12}{|l|}{ Ratio of debt service to: } \\
\hline Exports of goods and services & 10 & 18 & 7 & 5 & 6 & 7 & 15 & 14 & 15 & 14 & 14 \\
\hline Central government revenue & 35 & 53 & 17 & 12 & 15 & 17 & 36 & 33 & 32 & 29 & 27 \\
\hline \multicolumn{12}{|c|}{ Rescheduling on Naples terms (flow rescheduling followed by a stock-of-debt operation; the same consolidation period) } \\
\hline \multicolumn{12}{|l|}{ Ratio of NPV of external debt to: } \\
\hline Exports of goods and services & 137 & 128 & 107 & 122 & 110 & 119 & 119 & 118 & 117 & 117 & 118 \\
\hline Central government revenue & 450 & 370 & 277 & 307 & 276 & 295 & 285 & 269 & 257 & 245 & 237 \\
\hline \multicolumn{12}{|l|}{ Ratio of debt service to: } \\
\hline Exports of goods and services & 10 & 18 & 7 & 5 & 6 & 7 & 7 & 7 & 8 & 8 & 9 \\
\hline Central government revenue & 35 & 53 & 17 & 12 & 15 & 16 & 17 & 17 & 18 & 17 & 18 \\
\hline \multicolumn{12}{|l|}{ Assumptions } \\
\hline Real GDP growth & 8.3 & 10.0 & 6.0 & 5.0 & 4.0 & 4.0 & 4.0 & 4.0 & 3.0 & 3.0 & 3.0 \\
\hline \multicolumn{12}{|l|}{ Growth in external trade: } \\
\hline Exports of goods and services & 18.3 & 0.6 & 7.9 & 9.9 & 5.7 & 5.9 & 6.2 & 5.9 & 5.6 & 5.6 & 5.6 \\
\hline Imports of goods and services & 20.4 & 6.7 & 2.9 & 8.5 & 5.6 & 5.3 & 5.6 & 5.8 & 5.5 & 5.4 & 5.4 \\
\hline RER change (against US dollar) $1 /$ & 11.8 & 2.8 & 2.7 & 4.4 & 1.6 & 1.1 & 1.1 & 3.0 & 3.0 & 3.0 & 2.7 \\
\hline FDI (in percent of GDP) & 2.3 & 1.7 & 1.6 & 2.0 & 2.0 & 2.0 & 2.0 & 2.0 & 2.0 & 2.0 & 2.0 \\
\hline Central government revenue (in percent of GDP) & 13.6 & 13.7 & 15.0 & 15.0 & 15.5 & 15.8 & 16.2 & 16.5 & 16.8 & 17.1 & 17.4 \\
\hline
\end{tabular}

Source: Staff projections.

1/ A positive sign means appreciation. 
Appendix Table 17b. Tajikistan: Debt Sustainability Analysis--Low-Case Scenario (In percent)

\begin{tabular}{|c|c|c|c|c|c|c|c|c|c|c|c|}
\hline & 2000 & 2001 & 2002 & 2003 & 2004 & 2005 & 2006 & 2007 & 2008 & 2009 & 2010 \\
\hline \multicolumn{12}{|l|}{ No debt relief } \\
\hline \multicolumn{12}{|l|}{ Ratio of NPV of external debt to: } \\
\hline Exports of goods and services & 137 & 128 & 135 & 151 & 163 & 183 & 192 & 201 & 209 & 218 & 229 \\
\hline Central government revenue & 450 & 370 & 340 & 418 & 447 & 484 & 484 & 486 & 493 & 503 & 521 \\
\hline \multicolumn{12}{|l|}{ Ratio of debt service to: } \\
\hline Exports of goods and services & 10 & 18 & 20 & 18 & 19 & 19 & 20 & 21 & 23 & 23 & 24 \\
\hline Central government revenue & 35 & 53 & 50 & 50 & 52 & 49 & 51 & 51 & 53 & 52 & 54 \\
\hline \multicolumn{12}{|c|}{ Rescheduling on Naples terms (flow rescheduling with the consolidation period covering $\mathrm{H} 1 / 2002-\mathrm{H} 2 / 2004$ ) } \\
\hline \multicolumn{12}{|l|}{ Ratio of NPV of external debt to: } \\
\hline Exports of goods and services & 137 & 128 & 111 & 129 & 140 & 154 & 151 & 147 & 145 & 143 & 144 \\
\hline Central government revenue & 450 & 370 & 287 & 325 & 354 & 381 & 360 & 335 & 316 & 300 & 290 \\
\hline \multicolumn{12}{|l|}{ Ratio of debt service to: } \\
\hline Exports of goods and services & 10 & 18 & 7 & 5 & 6 & 7 & 16 & 15 & 15 & 15 & 15 \\
\hline Central government revenue & 35 & 53 & 17 & 13 & 15 & 18 & 37 & 35 & 34 & 31 & 30 \\
\hline \multicolumn{12}{|c|}{ Rescheduling on Naples terms (flow rescheduling followed by a stock-of-debt operation; the same consolidation period) } \\
\hline \multicolumn{12}{|l|}{ Ratio of NPV of external debt to: } \\
\hline Exports of goods and services & 137 & 128 & 111 & 129 & 119 & 132 & 136 & 139 & 143 & 147 & 153 \\
\hline Central government revenue & 450 & 370 & 287 & 325 & 299 & 326 & 325 & 317 & 313 & 308 & 307 \\
\hline \multicolumn{12}{|l|}{ Ratio of debt service to: } \\
\hline Exports of goods and services & 10 & 18 & 7 & 5 & 6 & 7 & 8 & 8 & 9 & 9 & 10 \\
\hline Central government revenue & 35 & 53 & 17 & 13 & 15 & 17 & 19 & 19 & 20 & 19 & 20 \\
\hline \multicolumn{12}{|l|}{ Assumptions: } \\
\hline Real GDP growth & 8.3 & 10.0 & 1.5 & 1.5 & 1.5 & 1.5 & 1.5 & 1.5 & 1.0 & 1.0 & 1.0 \\
\hline \multicolumn{12}{|l|}{ Growth in external trade: } \\
\hline Exports of goods and services & 18.3 & 0.6 & 1.5 & 3.0 & 2.3 & 1.8 & 1.6 & 2.3 & 2.0 & 2.3 & 2.3 \\
\hline Imports of goods and services & 20.4 & 6.7 & 0.8 & 0.7 & 1.0 & 1.7 & 1.4 & 2.2 & 1.9 & 2.1 & 2.2 \\
\hline RER change (against US dollar) 1/ & 11.8 & 2.8 & -1.7 & -2.0 & -2.0 & -2.0 & -2.0 & -2.0 & -2.0 & -2.0 & -2.0 \\
\hline FDI (in percent of GDP) & 2.3 & 1.7 & 1.6 & 1.5 & 1.5 & 1.4 & 1.3 & 1.1 & 1.1 & 1.1 & 1.1 \\
\hline Central government revenue (in percent of GDP) & 13.6 & 13.7 & 14.0 & 14.2 & 14.4 & 14.6 & 14.8 & 15.0 & 15.0 & 15.0 & 15.0 \\
\hline
\end{tabular}

Source: Staff projections.

1/ A positive sign means appreciation. 
Appendix Table 18a. Tajikistan: Medium-Term Projections, 2000-2005, Baseline Scenario

\begin{tabular}{|c|c|c|c|c|c|c|}
\hline & 2000 & 2001 & 2002 & 2003 & 2004 & 2005 \\
\hline & \multicolumn{6}{|c|}{ (Annual percentage change, unless otherwise indicated) } \\
\hline \multicolumn{7}{|l|}{ National income and prices } \\
\hline Nominal GDP (in millions of somoni) & 1,807 & 2,600 & 3,025 & 3,399 & 3,711 & 4,053 \\
\hline Nominal GDP (in millions of U.S. dollars) & 955 & 1,077 & 1,210 & 1,359 & 1,470 & 1,581 \\
\hline GDP per capita (in U.S. dollars) & 150 & 165 & 181 & 199 & 210 & 220 \\
\hline Real GDP (percent change) & 8.3 & 10.0 & 6.0 & 5.0 & 4.0 & 4.0 \\
\hline GDP deflator (percent change) & 24.8 & 32.3 & 8.2 & 7.0 & 5.0 & 5.0 \\
\hline Consumer prices (percent change, average) & 32.9 & 38.5 & 8.9 & 7.6 & 6.0 & 5.0 \\
\hline \multirow[t]{2}{*}{ Real exchange rate (against USD; percent change) } & 11.8 & 2.8 & 2.7 & 4.4 & 1.6 & 1.1 \\
\hline & \multicolumn{6}{|c|}{ (In percent of GDP) } \\
\hline \multicolumn{7}{|l|}{ Savings and investment balances } \\
\hline Total investment & $\ldots$ & 9.4 & 7.9 & 8.5 & 9.4 & 10.2 \\
\hline Public & $\ldots$ & 6.4 & 5.9 & 5.5 & 5.9 & 6.2 \\
\hline Private & $\ldots$ & 3.0 & 2.0 & 3.0 & 3.5 & 4.0 \\
\hline Total domestic savings & $\ldots$ & 1.7 & 2.0 & 3.4 & 4.1 & 5.4 \\
\hline Public & $\ldots$ & 1.9 & 1.5 & 1.4 & 1.5 & 1.5 \\
\hline Private & $\ldots$ & -0.2 & 0.5 & 2.0 & 2.6 & 3.9 \\
\hline Foreign savings & -6.5 & -7.7 & -5.9 & -5.1 & -5.2 & -4.8 \\
\hline \multicolumn{7}{|l|}{ General government } \\
\hline Total revenue and grants & 13.6 & 13.7 & 15.2 & 15.1 & 15.5 & 15.8 \\
\hline Of which: Grants & 0.7 & 0.0 & 0.2 & 0.1 & 0.0 & 0.0 \\
\hline Total expenditure & 14.2 & 15.1 & 15.5 & 15.4 & 15.8 & 16.1 \\
\hline Non-interest expenditure & 11.1 & 14.3 & 13.2 & 13.7 & 14.2 & 14.7 \\
\hline Interest & 0.4 & 0.6 & 2.1 & 1.5 & 1.4 & 1.2 \\
\hline Capital expenditure plus net lending & 2.7 & 0.2 & 0.2 & 0.2 & 0.2 & 0.2 \\
\hline \multicolumn{7}{|l|}{ Budget balance } \\
\hline Overall fiscal balance & -0.6 & -0.5 & -0.5 & -0.4 & -0.3 & -0.3 \\
\hline Primary balance & -0.3 & 0.1 & 1.6 & 1.1 & 1.1 & 0.9 \\
\hline Primary balance excluding investment & -3.0 & 0.3 & 1.8 & 1.3 & 1.3 & 1.1 \\
\hline & \multicolumn{6}{|c|}{ (In millions of U.S. dollars, unless otherwise indicated) } \\
\hline \multicolumn{7}{|l|}{ External sector } \\
\hline Exports & 788 & 796 & 856 & 940 & 994 & 1,053 \\
\hline Imports & 834 & 892 & 912 & 988 & 1,041 & 1,096 \\
\hline Gross international reserves & 87 & 100 & 121 & 136 & 149 & 159 \\
\hline $\begin{array}{l}\text { Gross international reserves (in months of imports } \\
\text { of goods and nonfactor services) }\end{array}$ & 2.1 & 2.3 & 2.5 & 2.6 & 2.7 & 2.7 \\
\hline \multicolumn{7}{|l|}{ Debt ratios (in percent) } \\
\hline NPV of public debt-to-exports ratio & 137 & 128 & 128 & 130 & 127 & 128 \\
\hline NPV of public debt-to-revenue ratio & 450 & 370 & 330 & 326 & 321 & 317 \\
\hline Total public debt service to exports ratio & 10 & 18 & 43 & 38 & 35 & 31 \\
\hline Total public debt service to revenue ratio & 35 & 53 & 50 & 41 & 40 & 35 \\
\hline
\end{tabular}

Sources: Tajik authorities; and staff estimates. 
Appendix Table 18b. Tajikistan: Medium-Term Projections, 2000-2005, Low Case Scenario

\begin{tabular}{|c|c|c|c|c|c|c|}
\hline & 2000 & 2001 & 2002 & 2003 & 2004 & 2005 \\
\hline & \multicolumn{6}{|c|}{ (Annual percentage change, unless otherwise indicated) } \\
\hline \multicolumn{7}{|l|}{ National income and prices } \\
\hline Nominal GDP (in millions of somoni) & 1,807 & 2,600 & 2,771 & 2,869 & 2,970 & 3,075 \\
\hline Nominal GDP (in millions of U.S. dollars) & 955 & 1,077 & 1,210 & 1,128 & 1,149 & 1,169 \\
\hline GDP per capita (in U.S. dollars) & 150 & 165 & 181 & 165 & 164 & 163 \\
\hline Real GDP (percent change) & 8.3 & 10.0 & 1.5 & 1.5 & 1.5 & 1.5 \\
\hline GDP deflator (percent change) & 24.8 & 32.3 & 5.0 & 2.0 & 2.0 & 2.0 \\
\hline Consumer prices (percent change, average) & 32.9 & 38.5 & 8.9 & 7.6 & 6.0 & 5.0 \\
\hline \multirow[t]{2}{*}{ Real exchange rate (against USD; percent change) } & 11.8 & 2.8 & -1.7 & -2.0 & -2.0 & -2.0 \\
\hline & \multicolumn{6}{|c|}{ (In percent of GDP) } \\
\hline \multicolumn{7}{|l|}{ Savings and investment balances } \\
\hline Total investment & $\ldots$ & 7.2 & 6.1 & 6.9 & 7.8 & 8.7 \\
\hline Public & $\ldots$ & 4.2 & 4.1 & 3.9 & 4.3 & 4.7 \\
\hline Private & $\ldots$ & 3.0 & 2.0 & 3.0 & 3.5 & 4.0 \\
\hline Total domestic savings & $\ldots$ & -0.5 & -2.6 & -2.2 & -0.9 & -0.2 \\
\hline Public & $\ldots$ & -1.2 & -1.1 & -0.9 & -1.2 & -1.3 \\
\hline Private & $\ldots$ & 0.7 & -1.5 & -1.3 & 0.3 & 1.1 \\
\hline Foreign savings & -6.5 & -7.7 & -8.8 & -9.1 & -8.7 & -8.8 \\
\hline \multicolumn{7}{|l|}{ General government } \\
\hline Total revenue and grants & 13.6 & 13.7 & 14.2 & 14.3 & 14.4 & 14.6 \\
\hline Of which: Grants & 0.7 & 0.0 & 0.2 & 0.1 & 0.0 & 0.0 \\
\hline Total expenditure & 14.2 & 15.1 & 15.5 & 15.4 & 15.8 & 16.1 \\
\hline Non-interest expenditure & 11.1 & 14.3 & 13.2 & 13.7 & 14.2 & 14.7 \\
\hline Interest & 0.4 & 0.6 & 2.1 & 1.5 & 1.4 & 1.2 \\
\hline Capital expenditure plus net lending & 2.7 & 0.2 & 0.2 & 0.2 & 0.2 & 0.2 \\
\hline \multicolumn{7}{|l|}{ Budget balance } \\
\hline Overall fiscal balance & -0.6 & -1.4 & -1.3 & -1.1 & -1.4 & -1.5 \\
\hline Primary balance & -0.3 & -0.8 & 0.8 & 0.4 & 0.0 & -0.3 \\
\hline Primary balance excluding investment & -3.0 & -1.0 & 0.6 & 0.2 & -0.2 & -0.5 \\
\hline & \multicolumn{6}{|c|}{ (In millions of U.S. dollars, unless otherwise indicated) } \\
\hline \multicolumn{7}{|l|}{ External sector } \\
\hline Exports & 788 & 796 & 802 & 816 & 832 & 843 \\
\hline Imports & 834 & 892 & 894 & 904 & 911 & 926 \\
\hline Gross international reserves & 87 & 100 & 121 & 136 & 149 & 159 \\
\hline Gross international reserves (in months of imports & 2.1 & 2.3 & 2.5 & 2.9 & 3.2 & 3.4 \\
\hline of goods and nonfactor services) & & & & & & \\
\hline \multicolumn{7}{|l|}{ Debt ratios (in percent) } \\
\hline NPV of public debt-to-exports ratio & 137 & 128 & 135 & 151 & 163 & 183 \\
\hline NPV of public debt-to-revenue ratio & 450 & 370 & 340 & 418 & 447 & 484 \\
\hline Total public debt service to exports ratio & 10 & 18 & 20 & 18 & 19 & 19 \\
\hline Total public debt service to revenue ratio & 35 & 53 & 50 & 50 & 52 & 49 \\
\hline
\end{tabular}

Sources: Tajik authorities; and staff estimates. 
Appendix Table 19. Azerbaijan: Medium Term Projections, 2000-2005, Baseline Scenario

\begin{tabular}{|c|c|c|c|c|c|c|}
\hline & 2000 & 2001 & 2002 & 2003 & 2004 & 2005 \\
\hline \multicolumn{7}{|l|}{ Income and prices } \\
\hline Nominal GDP (bln manats) & 23,565 & 26,226 & 28,343 & 31,440 & 34,886 & 39,847 \\
\hline Nominal GDP (millions of USD) & 5,270 & 5,693 & 6,098 & 6,764 & 7,506 & 8,573 \\
\hline GDP per capita (USD) & 652 & 699 & 743 & 817 & 900 & 1,020 \\
\hline Real GDP growth & 11.1 & 8.5 & 8.5 & 8.5 & 8.0 & 12.7 \\
\hline Consumer prices (average) & 1.8 & 2.0 & 3.3 & 3.5 & 3.3 & 2.8 \\
\hline RER change (against USD; percent) & -10.5 & $\ldots$ & $\ldots$ & $\ldots$ & $\ldots$ & $\ldots$ \\
\hline \multicolumn{7}{|l|}{ Savings and investment balances (all as share in GDP) } \\
\hline Total investment & 25.8 & 34.0 & 51.7 & 63.7 & 60.6 & 56.8 \\
\hline Public & 2.1 & 2.5 & 3.1 & 3.1 & 4.2 & 4.5 \\
\hline On-budget investment & $\ldots$ & $\ldots$ & $\ldots$ & $\ldots$ & $\ldots$ & $\ldots$ \\
\hline Other public investment & $\ldots$ & $\ldots$ & $\ldots$ & $\ldots$ & $\ldots$ & $\ldots$ \\
\hline Private & 23.7 & 31.6 & 48.6 & 60.6 & 56.4 & 52.3 \\
\hline Total domestic savings & 22.9 & 25.5 & 24.7 & 23.2 & 21.9 & 27.2 \\
\hline Public & 3.3 & 2.9 & 2.9 & 3.4 & 2.7 & 3.1 \\
\hline Private & 19.6 & 22.7 & 21.8 & 19.8 & 19.2 & 24.1 \\
\hline Foreign savings & 2.9 & 8.5 & 27.0 & 40.5 & 38.7 & 29.7 \\
\hline \multicolumn{7}{|l|}{ Central government (all as share in GDP) $1 /$} \\
\hline Total revenue and grants & 18.4 & 21.3 & 22.8 & 22.7 & 22.4 & 22.3 \\
\hline $\mathrm{o} / \mathrm{w}$ Grants & 0.5 & 0.1 & 0.2 & 0.2 & 0.1 & 0.1 \\
\hline Total expenditure & 20.9 & 21.1 & 23.3 & 22.3 & 23.7 & 23.5 \\
\hline Non-interest expenditure & 20.5 & 20.7 & 22.9 & 21.9 & 23.4 & 23.3 \\
\hline Interest & 0.4 & 0.5 & 0.4 & 0.3 & 0.3 & 0.3 \\
\hline Capital expenditure plus net lending & 3.0 & 3.5 & 4.5 & 4.4 & 6.0 & 6.4 \\
\hline Budget balance & 1.3 & 0.2 & -0.4 & 0.4 & -1.3 & -1.2 \\
\hline Overall budget balance & 1.3 & 0.2 & -0.4 & 0.4 & -1.3 & -1.2 \\
\hline Primary balance & 1.7 & 0.6 & 0.0 & 0.8 & -1.0 & -1.0 \\
\hline Primary balance excluding investment & 4.7 & 4.2 & 4.4 & 5.2 & 5.0 & 5.4 \\
\hline \multicolumn{7}{|l|}{ External sector } \\
\hline Exports of GNFS (millions of USD) & 2,146 & 2,235 & 2,092 & 2,077 & 2,068 & 2,627 \\
\hline Imports of GNFS (millions of USD) & $-2,024$ & $-2,416$ & $-3,489$ & $-4,595$ & $-4,807$ & $-4,882$ \\
\hline Gross reserves, excluding pledged (millions of USD) & 680 & 637 & 747 & 811 & 854 & 927 \\
\hline International reserves (months of imports of GNFS) & 4.0 & 3.2 & 2.6 & 2.1 & 2.1 & 2.3 \\
\hline \multicolumn{7}{|l|}{ Debt ratios } \\
\hline NPV of public debt-to-exports ratio & $\ldots$ & $\ldots$ & $\ldots$ & $\ldots$ & $\ldots$ & $\ldots$ \\
\hline NPV of public debt-to-revenue ratio & $\ldots$ & $\ldots$ & $\ldots$ & $\ldots$ & $\ldots$ & $\ldots$ \\
\hline Total public debt service to exports ratio & 4.7 & 6.4 & 7.0 & 8.6 & 7.2 & 5.1 \\
\hline Total public debt service to revenue ratio & 10.3 & 11.7 & 10.4 & 11.7 & 8.9 & 7.0 \\
\hline
\end{tabular}

Sources: Azerbaijan authorities; and staff estimates.

1/ Consolidated central government. 
Appendix Table 20. Azerbaijan: Structure of External Debt, 1999-2000 (In millions of U.S. dollars)

\begin{tabular}{lrr}
\hline & 1999 & 2000 \\
\hline Nominal Figures & & \\
Total External Liabilities & 970 & 1,213 \\
Total government and govt. guaranteed debt & 970 & 1,213 \\
Multilateral creditors & 663 & 714 \\
World Bank & 192 & 219 \\
IMF & 366 & 375 \\
Other multilateral & 105 & 120 \\
Bilateral creditors & & \\
Russia & 258 & 400 \\
Other FSU & $\ldots$ & $\ldots$ \\
Other Paris Club & 25 & 25 \\
Other bilateral & 91 & 241 \\
Commercial and Guaranteed debt & 142 & 135 \\
Non-Guaranteed Debt & 49 & 98 \\
\hline
\end{tabular}

Sources: national authorities; and staff estimates. 
Appendix Table 21. Uzbekistan: Medium Term Projections, 2000-2005

\begin{tabular}{|c|c|c|c|c|c|c|}
\hline & 2000 & 2001 & 2002 & 2003 & 2004 & 2005 \\
\hline \multicolumn{7}{|l|}{ Income and prices } \\
\hline GDP (billion sums) & 3,195 & 4,730 & 6,300 & 7,327 & 8,299 & 9,412 \\
\hline GDP (billion U.S. dollars) 1/ & 13.2 & 11.1 & 7.8 & 8.4 & 8.9 & 9.6 \\
\hline GDP per capita (USD) & 536 & 443 & 306 & 322 & 337 & 356 \\
\hline Real GDP growth & 4.0 & 3.8 & 2.0 & 3.0 & 4.0 & 5.0 \\
\hline Consumer prices (average) & 25.0 & 27.1 & 23.7 & 12.4 & 8.9 & 8.0 \\
\hline RER change (against USD; percent) 2/ & -36.4 & -30.3 & -36.5 & 0.0 & 0.0 & 0.0 \\
\hline \multicolumn{7}{|l|}{ Savings and investment balances (as percent of GDP) } \\
\hline Total investment & 12.0 & 10.7 & 13.0 & 13.7 & 15.0 & 15.6 \\
\hline On-budget investment & 6.0 & 4.8 & 5.6 & 4.8 & 4.4 & 3.9 \\
\hline Other public and private investment & 6.0 & 5.9 & 7.4 & 8.9 & 10.6 & 11.7 \\
\hline Total domestic savings & 13.4 & 9.8 & 18.0 & 11.7 & 11.0 & 21.3 \\
\hline Government savings & 5.5 & 4.0 & 4.8 & 5.0 & 5.1 & 5.2 \\
\hline Private and other public savings & 7.9 & 5.8 & 13.2 & 6.7 & 5.9 & 16.2 \\
\hline Foreign savings & -1.4 & 0.9 & -5.0 & 2.0 & 4.0 & -5.8 \\
\hline \multicolumn{7}{|l|}{ Consolidated government (as percent of GDP) } \\
\hline Total revenues and grants & 28.5 & 26.8 & 26.7 & 27.1 & 27.3 & 27.4 \\
\hline of which: Grants & 0.0 & 0.0 & 0.0 & 0.0 & 0.0 & 0.0 \\
\hline Total expenditure & 30.7 & 29.1 & 29.7 & 29.2 & 28.6 & 28.1 \\
\hline Non-interest expenditure & 22.3 & 22.2 & 21.1 & 21.4 & 21.4 & 21.7 \\
\hline Interest & 0.7 & 0.6 & 0.8 & 0.8 & 0.7 & 0.6 \\
\hline Capital expenditure plus net lending & 7.8 & 6.3 & 7.9 & 7.0 & 6.5 & 5.8 \\
\hline \multicolumn{7}{|l|}{ Budget balance } \\
\hline Overall budget balance 3 / & -2.3 & -2.0 & -3.0 & -2.0 & -1.4 & -0.7 \\
\hline Primary balance & -1.6 & -1.4 & -2.2 & -1.2 & -0.7 & -0.1 \\
\hline Primary balance excluding investment & 4.4 & 3.4 & 3.4 & 3.6 & 3.7 & 3.8 \\
\hline \multicolumn{7}{|l|}{ External sector } \\
\hline Exports of GNFS (millions of U.S. dollars) & 3,383 & 3,219 & 3,381 & 3,586 & 3,893 & 4,198 \\
\hline Imports of GNFS (millions of U.S. dollars) & 2,961 & 3,130 & 3,284 & 3,644 & 4,065 & 4,455 \\
\hline Gross reserves (millions of U.S. dollars) & 1,273 & 1,200 & 1,200 & 1,200 & 1,200 & 1,299 \\
\hline Gross reserves ( in months of imports of GNFS) & 5.2 & 4.6 & 4.4 & 4.0 & 3.5 & 3.5 \\
\hline Total outstanding external debt (millions of US dollars) & 4,393 & 4,402 & 4,658 & 5,014 & 5,425 & 5,957 \\
\hline Total outstanding external debt (in percent of GDP) 1/ & 33.2 & 39.9 & 59.5 & 59.8 & 60.7 & 61.9 \\
\hline \multicolumn{7}{|l|}{ Debt ratios (percent) } \\
\hline NPV of public debt-to-exports ratio & $\ldots$ & $\ldots$ & $\ldots$ & $\ldots$ & $\ldots$ & $\ldots$ \\
\hline NPV of public debt-to-revenue ratio & $\ldots$ & $\ldots$ & $\ldots$ & $\ldots$ & $\ldots$ & $\ldots$ \\
\hline Total public debt service to exports ratio & 21.1 & 22.4 & 22.4 & 22.8 & 20.3 & 20.2 \\
\hline Total public debt service to total government revenue ratio $1 /$ & 18.9 & 24.8 & 40.8 & 37.6 & 33.0 & 32.5 \\
\hline
\end{tabular}

Sources: Uzbek authorities; and staff estimates.

$1 /$ GDP and total government revenue are converted at the official exchange rate in 2000-2001 and at the OTC rate thereafter.

2/ For the official exchange rate in 2000-2001 and for the OTC rate thereafter.

$3 /$ Includes the operations of extrabudgetary funds. 
Appendix Table 22. Uzbekistan: Structure of External Debt, 1999-2000 (In millions of U.S. dollars)

\begin{tabular}{lrr}
\hline & 1999 & 2000 \\
\hline Total external liabilities & 4,340 & 4,393 \\
Total government and government-guaranteed & 3,825 & 4,018 \\
Multilateral creditors & 653 & 686 \\
IBRD & 224 & 250 \\
AsDB & 20 & 83 \\
IMF & 202 & 127 \\
EBRD & 145 & 157 \\
Other multilateral & 62 & 67 \\
& & \\
Bilateral creditors & & 951 \\
Russia 1/ & 897 & 507 \\
Other bilateral & 507 & 444 \\
Commercial debt and short-term debt & 390 & \\
& & \\
Non-guaranteed debt and other debt & 2,276 & 2,382 \\
\hline
\end{tabular}

Sources: Uzbek authorities; and staff estimates.

1/ Includes technical credits by Russia to Uzbekistan during 1992-94, the settlement of which (a total of US\$ 507 million) is still in dispute. 